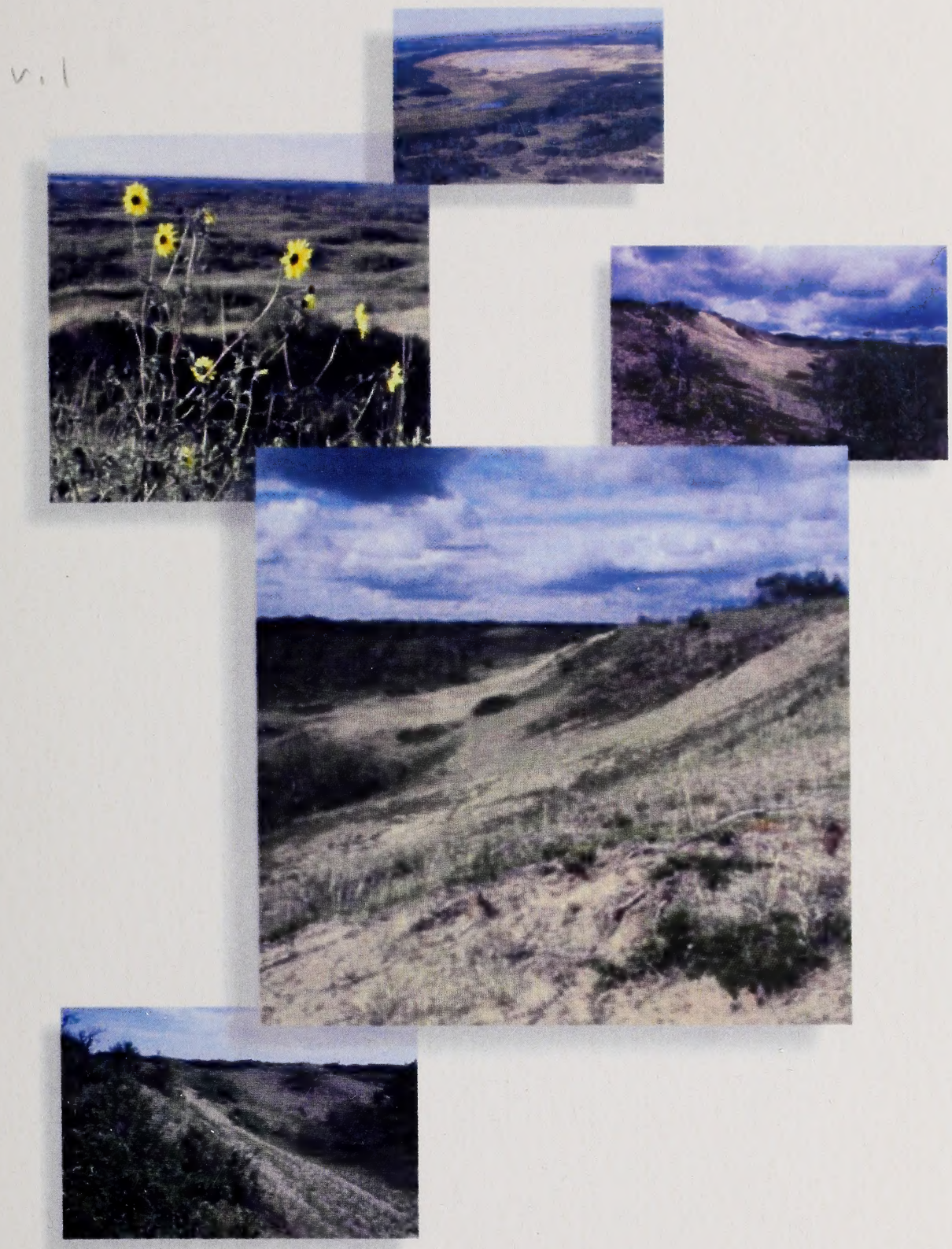

\title{
A Rare Plant Survey of the Wainwright Dunes Ecological Reserve
}

Resource Data Branch, Strategic Corporate Services 


\title{
A RARE PLANT SURVEY \\ OF THE \\ WAINWRIGHT DUNES \\ ECOLOGICAL RESERVE
}

\author{
by \\ Ian D. Macdonald \\ Calgary AB / Terre Haute IN
}

March 2003

for

Alberta Sustainable Resource Development

Resource Data Branch

Public Lands Division

Edmonton $\mathrm{AB}$ 



\section{EXECUTIVE SUMMARY}

The Wainwright Dunes Ecological Reserve is administered by Alberta Community Development, Parks and Protected Areas Branch. Its 2821 ha present a provincially significant landform of sand dune ridges, alkaline seeps and lake basins, and patterned fens which provide habitat for 19 provincially rare vascular plant species with provincial conservation Ranks within Alberta of S1, S1S2, S2, S2S3, S3W. This report presents the findings of a three phase, 20-day long, on-site inventory of rare plants in order to confirm their previously reported locations, populations and habitats, and to discover and document additional species locations within the Reserve.

Eleven previously known rare species from the Ecological Reserve were relocated, and additional locations were discovered within (indicated by $\mathbb{I N}$ ) and outside of (indicated by (OUT) the Reserve boundaries, as follows (? indicates taxonomic problem):

S1S2 Carex parryana var. parryana (Parry's sedge) - IN: 10 species locations with 12621 plants (OUT: 4 species locations with 11025 plants)

S2 Muhlenbergia asperifolia (scratch grass) - IN: 3 species locations with 72780 plants (OUT: 4 species locations with over three million plants)

S2 Carex crawei (Crawe's sedge) - IN: 0 species location with 0 plants (OUT: 1 Species locations with 13 plants)

S2 Cyperus schweinitzii (sand nut-grass) - IN: 15 species locations with 9123 plants

S2 Lycopus americanus (American water-horehound) - IN: 16 species locations with 887 plants (OUT: 1 species location with 15 plants)

S2 Aster pauciflorus (few-flowered aster) - IN: 9 species locations with 551 plants (OUT: 1 species location with 6,000 plants)

S2 Shinneroseris rostrata (annual skeletonweed) - IN: 18 species locations with 257 plants

S2S3 Gentiana fremontii (marsh gentian) IN: 2 species locations with 3 plants (OUT: 4 species locations with unknown number of plants)

S3W Asclepias ovalifolia (low milkweed) - IN: 16 species locations with 1317 plants

SU Eleocharis ? elliptica (slender spike-rush) - IN: 1 species location with about 6 plants 
SU Chenopodium ?leptophyllum (narrow-leaved goosefoot) - IN: 7 species locations with 164 plants

Eight species that were reported in previous biophysical and other studies within or adjacent to the reserve could not be relocated, and hence, no new species information is available, as follows:

S1 Elodea ?bifoliata (two-leaved waterweed) 1 former species location with unknown number plants

S1S2 Najas flexilis (slender naiad) 1 former species location with unknown number of plants

S1S2 Ruppia cirrhosa (widgeon-grass) 3 former species locations with unknown number of plants

S2 Botrychium multifidum (leather grape-fern) 1 former species location with unknown number of plants

S2 Carex?houghtoniana (Houghton's sedge) 1 former species location with unknown number of plants

S2 Drosera linearis (slender-leaved sundew) 5 former species locations with unknown number of plants

S2 Hedyotis longifolia (long-leaved bluets) 1 former species location with unknown number of plants

S2S3 Veronica catenata (water speedwell) 1 former species location with unknown number of plants

There are notable concentrations of the rare species occur in association with the Ecological Reserve's distinctive habitats, as follows (+ indicates not recorded in 2002, ? indicates taxonomic problem) from habitats associated with the sand dune ridges (Carex?houghtoniana+, Cyperus schweinitzii, Chenopodium ?leptophyllum, Shinneroseris rostrata), grasslands (Asclepias ovalifolia), forests (Botrychium multifidum+), seepage slopes (Carex crawei, Gentiana fremontii, Lycopus americanus), wetlands (Eleocharis ?elliptica, Lycopus americanus, Veronica catenata+), ponds (Elodea bifoliata+, Najas flexilis+), and patterned fen (Drosera linearis), and the David Lake basin (Ruppia cirrhosa, Muhlenbergia asperifolia, Carex parryana var. parryana, Aster 
pauciflorus, Lycopus americanus).

The major habitat threats to the survival of the species are related to the effects of the prolonged drought conditions, with minor grazing and very local illicit use impacts, and management concerns mostly involve monitoring these effects and conducting supplemental surveying during a moister climatic year. 


\section{ACKNOWLEDGEMENTS}

The following persons provided background information, guidance and patience in assisting the author's execution of this project:

Keith Ainsley (Vegetation Ecologist, Alberta Sustainable Resource Development, Resource Data Branch, Edmonton) for his guidance and patience in the execution of this project, and his advice in writing the report and preparing the species location data; Harry Loonen (Rangeland Agrologist, Alberta Sustainable Resource Development, Public Lands Division, Wainwright) and Patrick Porter (Land Use Agrologist, Alberta Sustainable Resource Development, Public Lands Division, Wainwright) for facilitating access to the Reserve and providing much background information on the history and land-use of the Reserve and of former floral surveys; Ksenija Vujnovic (Botanist, Alberta Natural Heritage Information Centre, Edmonton) for clarifying the provincial Rank and distribution of the rare species, and providing much advice on the technical content of the report; Patsy Cotterill (Research Assistant, Alberta Natural Heritage Information Centre, Edmonton) for clarifying the characteristics and confirming the determinations of several rare species; John Rintoul (Data Manager, Alberta Natural Heritage Information Centre, Edmonton) for providing rare species information; Bonnie M. Smith (Herbarium Technician, Vascular Plant Herbarium, University of Calgary, Calgary) for facilitating access to the herbarium collections, confirming several determinations, and sharing her personal information on the species ecologies; Cliff Wallis (Cottonwood Consultants, Ltd., Calgary) for clarifying information on his several records of species locations within the Reserve.

Front cover photos courtesy of Patrick Porter, Public Lands Officer, Public Lands and Forests Division, Alberta Sustainable Resource Development, Wainwright, Alberta. 


\section{IABLE OF CONTENTS}

EXECUTIVE SUMMARY

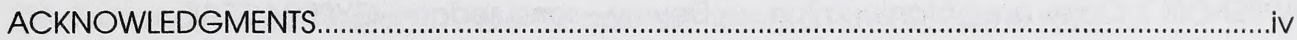

INTRODUCTION

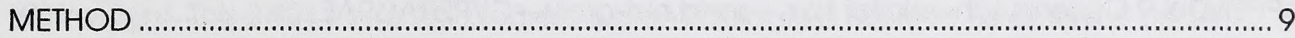

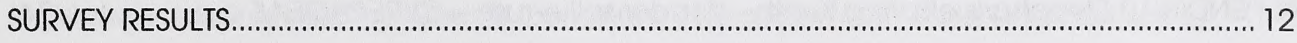

Botrychium multifidum var. intermedium (leather grape fern) ....................................... 12

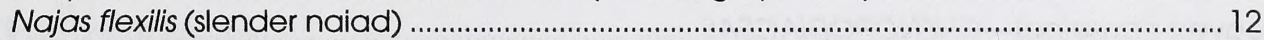

Ruppia cirrhosa (widgeon-grass) ,............................................................................ 13

Elodea bifoliata (two-leaved waterweed) ) ................................................................... 13

Muhlenbergia asperifolia (scratch grass) ..................................................................... 14

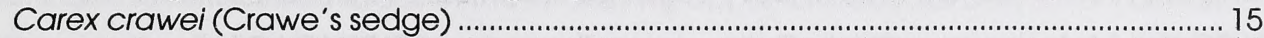

Carex houghtoniana (Houghton's sedge)................................................................. 15

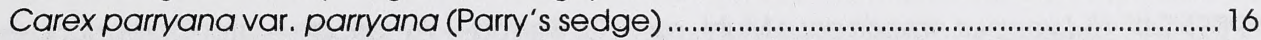

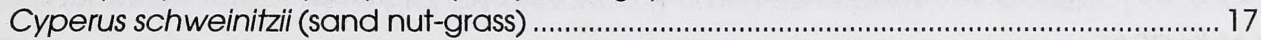

Eleocharis ? elliptica (slender spike-rush) ..................................................................... 17

Chenopodium ?leptophyllum (narrow-leaved goosefoot)................................................. 18

Drosera linearis (slender-leaved sundew) ..................................................................... 18

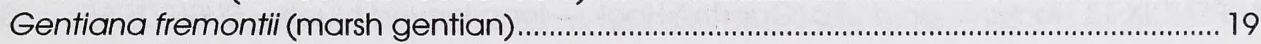

Asclepias ovalifolia (low milkweed) ........................................................................... 19

Lycopus americanus (American water-horehound) ......................................................... 20

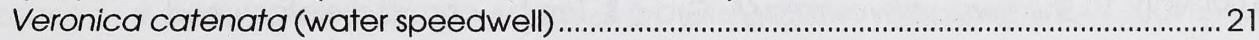

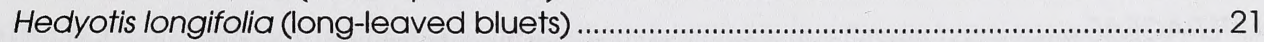

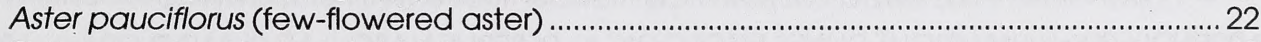

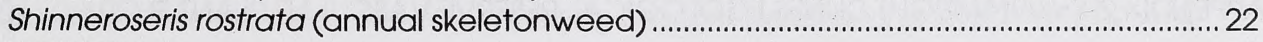

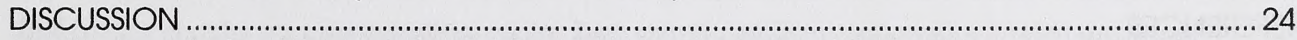

HABITAT THREATS

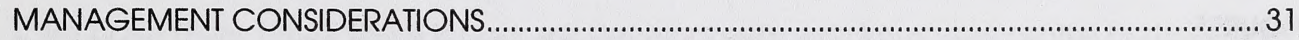

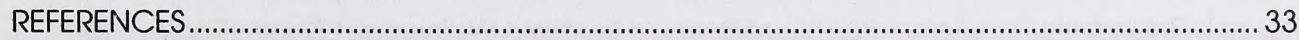

\section{APPENDICES}

APPENDIX I Botrychium multifidum (S.G. Gmelin) Rupr. var. intermedium (D.C. Eat.) Farw.

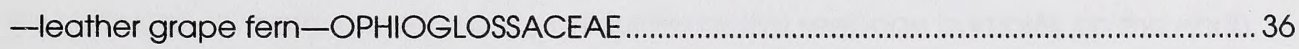

APPENDIX 2 Najas flexilis (Willd.) Rostk. \& Schmidt. — slender naiad-NAJADACEAE ........ 39

APPENDIX 3 Ruppia cirrhosa (Petagna) Grande-widgeon-grass-RUPPIACEAE ............... 42

APPENDIX 4 Elodea bifoliata St John.-two-leaved waterweed-HYDROCHARITACEAE . 46 
APPENDIX 5 Muhlenbergia asperifolia (Nees \& Meyer ex Trin.) Parodi-scratch grassPOACEAE. 49

APPENDIX 6 Carex crawei Dewey - Crawe's sedge-CYPERACEAE ....................................5 55

APPENDIX 7 Carex houghtoniana Torr. ex Dewey-sand sedge-CYPERACEAE.................60

APPENDIX 8 Carex parryana Dewey var. parryana-Parry's sedge-CYPERACEAE ...........63

APPENDIX 9 Cyperus schweinitzii Torr.-sand nut-grass_CYPERACEAE................................6. 69

APPENDIX 10 Eleocharis elliptica Kunth-slender spike-rush_CYPERACEAE _........................74

APPENDIX 11 Chenopodium leptophyllum (Nutt. ex Moq.) Nutt. ex S. Wats.-narrowleaved goosefoot-CHENOPODIACEAE

APPENDIX 12 Drosera linearis Goldie-slender-leaved sundew-DROSERACEAE ............... 82

APPENDIX 13 Gentiana fremontii Torr.-marsh gentian-GENTIANACEAE............................. 86

APPENDIX 14 Asclepias ovalifolia Dcne.-low milkweed-ASCLEPIADACEAE ..................... 92

APPENDIX 15 Lycopus americanus Muhl. ex W.C. Barton- American water-horehound-

LAMIACEAE 97

APPENDIX 16 Veronica catenata Pennell.-water speedwell-SCROPHULARIACEAE.... 103 APPENDIX 17 Hedyotis longifolia (Gaertn.) Hook. - long-leaved bluets-RUBIACEAE ..... 106 APPENDIX 18 Aster pauciflorus Nutt._few-flowered aster-ASTERACEAE ......................... 109 APPENDIX 19 Shinnersoseris rostrata (A. Gray) S. Tomb-annual skeletonweedASTERACEAE 114 APPENDIX 20: WAINWRIGHT DUNES ECOLOGICAL RESERVE VASCULAR PLANT FLORA .....120 REFERENCES.

\section{FIGURES}

Figure 1. Boundaries and geographic reference features Wainwright Dunes Ecological Reserve. 


\section{INTRODUCTION}

The Wainwright Dunes Ecological Reserve (Figure 1) is located in the eastern portion of the Parkland Natural Region in Alberta, approximately $30 \mathrm{~km}$ SSE of the town of Wainwright, and adjacent to the southern border of the southeastern arm of CFB Wainwright. This 2821 ha (6 970 ac.) area is an Ecological Reserve established under legislation administered by Alberta Community Development, Parks and Protected Areas, and managed in cooperation with Alberta Sustainable Resource Development, Public Lands Division.

There are no bedrock outcrops of the underlying Upper Cretaceous Belly River Formation within the Reserve (Fehr 1984). The surficial geology of the central portion of the Reserve is predominantly a gently to strongly and sharply rolling sand plain that features parallel, long ridges that are modified parabolic dunes with strongly asymmetrical arms, as well as several extensive outwash / lacustrine depressions that support organic deposits, all of which trend from northwest to southeast. A notable depressional deposit is the Great Fen, which presents patterned fen terrain features. Along the northern, western and eastern portions is a gently rolling outwash plain, with a kame moraine that has high relief in the northeastern corner. In the southeastern portion is the David Lake basin which experiences considerable drawdown during drought periods, and which in 2002 was essentially a mile square alkaline plain. Two small aeolian depressions with wetland features occur along the Reserve's eastern boundary and to the southwest of the David Lake basin (Fehr 1984). There is poor soil development with immature profile horizonation on the dry sandy terrain of the upland sites while the wetter lowland depressions support well-developed Dark Brown or Black Chernozem profiles and, in the fens, deep fibric organic soils (Fehr 1984). The David Lake basin was strongly alkaline, as is typical of many lakes in the region, and around the basin are saline seepage zones, with, under normal, non-droughty climatic conditions, a particularly active seepage complex on the north side of David Lake. David Lake is drained to the south by a creek and eventually into Ribstone Creek outside the Reserve (Fehr 1984). There are a limited number of streams and ponds in the Reserve, with the larger located to the northeast and southeast of the Great Fen. 


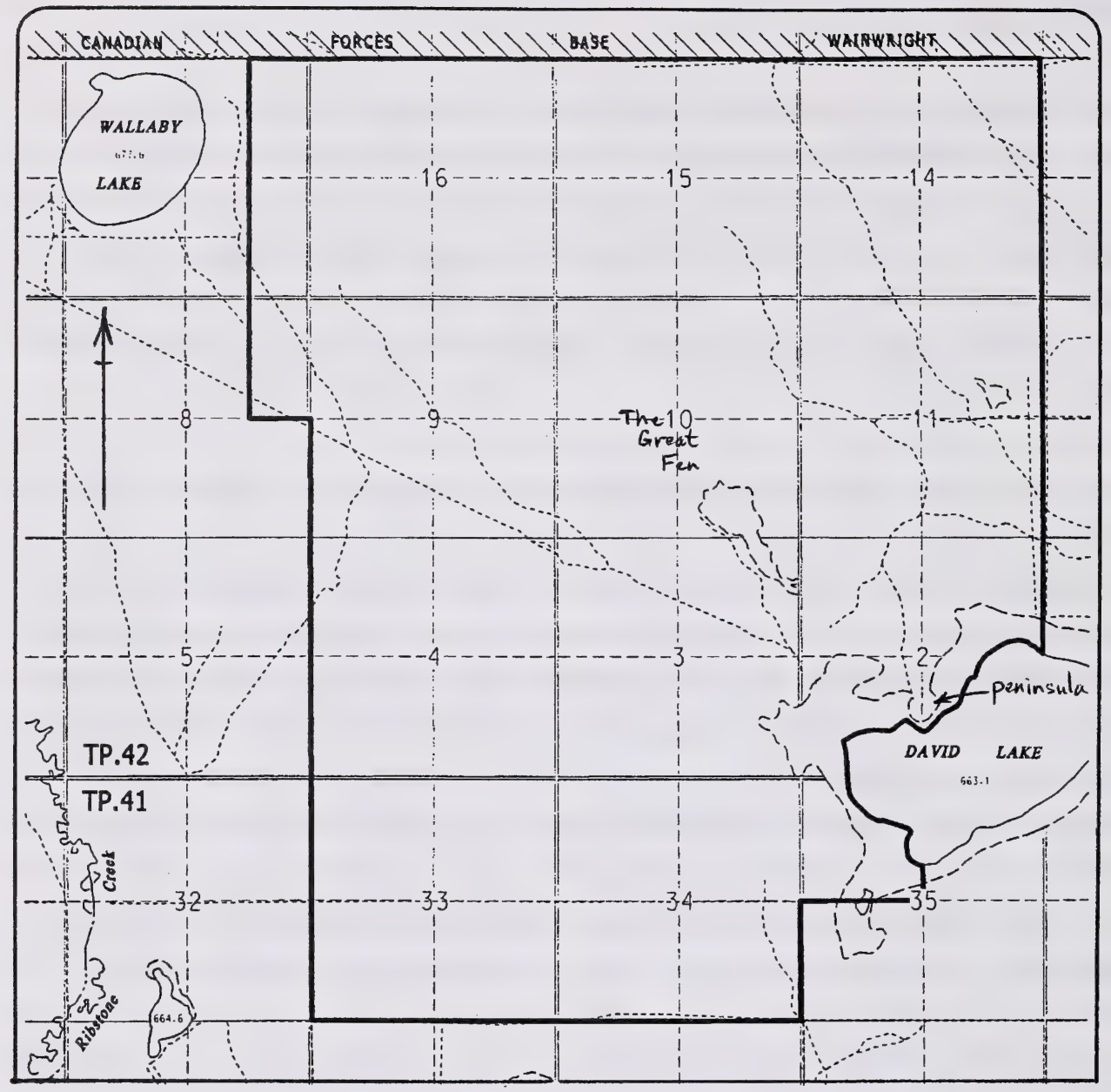

Figure 2: Boundaries and geographic reference features Wainwright Dunes Ecological Reserve. 
Land use within the Reserve has included several gas / oil exploration well sites and associated seismic and pipeline corridors that were installed over a decade ago, but are not actively productive at this time (Anon 1998). Grazing for cattle by local ranchers has been conducted since 1905, and has been managed by the Buffalo Park Grazing Association for the past 50 years; however, the current drought recently has reduced by half the number of cattle in the Reserve (Anon 1998, Maull 2002). The current land uses allowed within the Ecological Reserve include ongoing controlled grazing and limited public access, although vehicular use is not allowed (Anon 1998).

The vegetation of the Reserve consists of upland native grassland that extends over one third of the area, much of which experiences some degree of shrub and sapling succession. There is a distinctive xeric barrens vegetation on the blowouts along the sand ridges, aspen groves on the uplands and north-facing slopes. In the lowland depressions there are mixed balsam poplar - aspen forests, and in the wetland basins, along the stream courses and around the lake backshores, are thicket swamps and shrubby marshes including a notable development of fen vegetation in the Great Fen and local spring areas. The lake vegetation of David Lake varies from being a strongly alkaline meadow in dry years to aquatic vegetation in wet years. Most of these vegetation habitats also support the provincially rare species that are the concern of this report (Fehr 1984, Cottonwood Consultants, Ltd. 1986, Pearson Timberline Forestry Consultants 1993). A brief description of each major vegetation community follows:

The grassland communities include species that are representative of the Parkland Natural Region, such as Bouteloua gracilis (blue grama), Koeleria macrantha (June grass), Calamovilfa longifolia (sand grass), Festuca campestris (rough fescue), Poa sandbergii (Sandberg grass), Stipa curtiseta (western porcupine grass), Carex pensylvanica var. digyna (sun-loving sedge), Selaginella densa (prairie selaginella), Smilacina stellata (star-flowered Solomon's-seal), Comandra umbellata var. pallida (bastard toadflax), Antennaria parvifolia (small-flowered everlasting), Solidago missouriensis (low goldenrod), Lithospermum incisum (narrow-leaved puccoon) and others, including the provincially rare Asclepias ovalifolia (low milkweed). The upland open shrub thicket successional vegetation includes saplings of Populus tremuloides 
(aspen), and shrubs of Prunus virginiana (choke cherry) Rosa acicularis (prickly rose), Elaeagnus commutata (silverberry) and Symphoricarpos occidentalis (buckbrush).

The sand ridge blowouts often have an open cover of Calamovilfa longifolia, Carex pensylvanica var. digyna, Carex obtusata (blunt sedge), Carex siccata (hay sedge), Stipa curtiseta, Sporobolus cryptandrus (sand dropseed), Festuca saximontana (Rocky Mountain fescue), Oryzopsis hymenoides (Indian rice grass), Rumex venosus (wild begonia), Chamaerhodos erecta (chamaerhodos), Hudsonia tomentosa (sand heather), Juniperus horizontalis (creeping juniper), Helianthus couplandii (Coupland's sunflower), Lysimachia juncea (skeletonweed). Heterotheca villosa (golden aster), and others, including the rare Cyperus schweinitzii (sand nut-rush), Schinneroseris rostrata (annual skeletonweed), and perhaps Carex ?houghtoniana (Houghton's sedge) and Chenopodium ?leptophyllum (narrow-leaved goosefoot) (? indicates problematic determination).

The upland forests often have young tree canopies of Populus tremuloides, with shrub strata of Prunus virginiana, Rosa acicularis, Ribes oxyacanthoides (northern gooseberry), Spiraea alba (narrow-leaved meadowsweet), Symphoricarpos occidentalis,

Symphoricarpos albus (snowberry) and Viburnum edule (low-bush cranberry), and a herb cover of Carex pensylvanica var. digyna, Oryzopsis asperifolia (white-grained mountain rice grass), Oryzopsis pungens (northern rice grass), schizachne purpurascens (purple oat grass), Aster ciliolatus (Lindley's aster), Galium boreale (northern bedstraw), Thalictrum venulosum (veiny meadow rue), Maianthemum canadense (wild lily-of-the-valley) and others, including the rare Hedyotis longifolia (long-leaved bluets).

The lowland subhygric forests often are well-developed and more mature with a closed tree canopy of Populus balsamifera (balsam poplar), with some Populus tremuloides, a tall shrub stratum of Salix bebbiana (beaked willow), Viburnum opulus subsp. trilobum (high-bush cranberry), and Prunus virginiana, a low shrub stratum of Rosa acicularis, Symphoricarpos occidentalis, Cornus stolonifera (red-osier dogwood), Corylus cornuta (beaked hazelnut), Ribes americanum (wild black current) and others, and a herb cover of Aralia nudicaulis (wild sarsaparilla), Rubus pubescens (dewberry), Viola canadensis 
var. rugulosa (western Canada violet), Smilacina stellata, Maianthemum canadense, Linnaea borealis var. americana (twinflower), Pyrola asarifolia (common pink shinleaf) and others, including the provincially rare Botrychium multifidum var. intermedium (leather grape-fern).

Thicket swamps support a subhygric to hygric tall shrub cover of Betula occidentalis (water birch), Salix pseudomonticola (false mountain willow), Salix maccalliana (velvetfruited willow), Salix petiolaris (basket willow) and others, with an understory of several of the low shrub and wetland herb species, such as Ribes americanum, Cornus stolonifera, Rosa acicularis, Rubus pubescens, Fragaria virginiana var. glauca (wild strawberry), Carex utriculata (small bottle sedge), Viola nephrophylla (bog violet), Glyceria striata var. stricta (fowl meadow grass), Cicuta maculata var. angustifolia (water-hemlock) and others, including the provincially rare Lycopus americanus (American water-horehound) and Carex crawei (Crawe's sedge).

Marshes and marsh fringes include Carex aquatilis (water sedge), Carex utriculata, Calamagrostis canadensis (bluejoint), Eleocharis palustris (creeping spike-rush), Juncus balticus var. littoralis (wire rush), Eleocharis acicularis (needle spike-rush), Glyceria grandis (common tall manna grass), Potentilla anserina (silverweed), Sonchus uliginosus (smooth perennial sow-thistle) and others, including the provincially rare Lycopus americanus and perhaps Veronica catenata (water speedwell) and Eleocharis ?elliptica (slender spikerush).

The hygric to subhydric patterned and seepage fens support a flora of over 80 wetland species, many of which are distinctive and represent a northerly element in the flora, such as Calamagrostis inexpansa (northern reed grass), Triglochin maritima (seaside arrow-grass), Carex canescens (sedge), Carex diandra (two-stamened sedge), Carex gynocrates (northern bog sedge), Carex lanuginosa (wooly sedge), Carex leptalea (bristle-stalked sedge), Carex tenuiflora (thin-flowered sedge), Carex prairea (prairie sedge), Eriophorum polystachion (tall cotton-grass), Eriophorum gracile (slender cottongrass), Smilacina trifolia (three-flowered Solomon's-seal), Tofieldia glutinosa (sticky false asphodel), Platanthera obtusata (blunt-leaved bog orchid), Minuartia dawsoniensis 
(Dawson sandwort), Parnassia palustris var. neogaea (mealy primrose), Menyanthes trifoliata (buck-bean), Pedicularis groenlandica (elephant's-head), Galium labradoricum (Labrador bedstraw) and others, including the provincially rare Drosera linearis (slenderleaved sundew).

The backshore vegetation around the David Lake basin supports many alkaline species in their shrubby marsh vegetation, notably Carex capillaris var. chlorostachys (hair-like sedge), Carex viridula (green sedge), Carex scirpoidea (rush-like sedge), Eleocharis quinqueflora (few-flowered spike-rush), Juncus longistylis (long-styled rush), Senecio pauperculus (balsam groundsel), Parnassia palustris, Primula incana (mealy primrose), Dodecatheon pulchellum (saline shooting-star), Gentiana amarella subsp. acuta (felwort) and others, including the provincially rare Gentiana fremontii (marsh gentian), Carex crawei and Lycopus americanus. The near- to offshore vegetation in the David Lake basin includes Hordeum jubatum (foxtail barley), Carex utriculata, Scirpus validus (common great rush), Calamagrostis stricta (narrow reed grass), Deschampsia cespitosa (tufted hair grass), Puccinellia nuttalliana (Nuttall's salt-meadow grass), Glaux maritima (sea milkwort), Ranunculus cymbalaria (seaside buttercup), Potentilla anserina, Aster brachyactis (rayless aster), Scirpus pungens (three-square rush), Aster ericoides (tufted white prairie aster) and others, including the provincially rare Muhlenbergia asperifolia (scratch grass), Aster pauciflorus (few-flowered aster) and Carex parryana (Parry's sedge). The open waters of the lake and ponds, now much reduced during the 2002 survey due to the prolonged drought, support Potamogeton pectinatus (sago pondweed), Ranunculus circinatus (firm white water crowfoot), Hippuris vulgaris (common mare's-tail) and others, including reports of the provincially rare Najas flexilis (slender naiad), Ruppia cirrhosa (widgeon-grass) and Elodea ?bifoliata (two-leaved waterweed).

The vascular plant flora has been documented for twenty-five years through various surveys in the Ecological Reserve and its immediate vicinity by Bradley \& Bradley (1977), Fehr (1984), Cottonwood Consultants, Ltd. (1986), Wallis (1990), the Reserve's management plan (Anon 1998) and Miejer (2001), and through various collection and other recording sources, Johnson (1992), Cotterill (2000), ANHIC (2002), and now by the 
author of this report (Macdonald 2002). In all, the 506 taxa have been reported from the Reserve and its immediate vicinity through the above survey. These included 415 species records that have been confirmed as occurring within the current boundaries of the Ecological Reserve's, and that appear to have a reliable determination. As well, there are an additional ten records that only may tentatively be accepted due to nomenclatural or taxonomic problems. Within the Reserve, 33 of these species are nonnatives, generally of Eurasian origins. However, several of these reports were drawn from surveys of areas that were outside the current boundaries of the Ecological Reserve, particularly westward to the Wallaby Lake and Ribstone Creek areas and eastward to include Sections 12 and 13 of Township 42 (Bradley \& Bradley 1977, Fehr 1984. Cottonwood Consultants, Ltd. 1986). There areas supported an additional 31 species records that are confidently determined but have not yet been confirmed as actually occurring within the Reserve's boundaries. There were another 50 confident records for which there was insufficient information to confirm whether or not they occurred within or outside the Reserve's boundaries, 10 of these being non-native species (see Appendices).

The largest families listed within there Reserve are the Asteraceae (62 species), Poaceae (55) and Cyperaceae (53). During the 2002 survey, a total of 61 species that were observed or collected by Macdonald from within the Reserve were added to the Reserve's flora, and an additional five species that were added occurred outside of, but immediately adjacent to, the Reserve' boundaries. Additionally, 58 taxa appear to represent extensions to their ranges as mapped in the Flora of Alberta (Moss 1983). For the most part these occurred between 50 to $100 \mathrm{~km}$ from their next-nearest locations in the Grassland, Parkland and southern Boreal Natural Regions, but in several cases they were considerable extensions from their Rockies or far northern or western Parkland ranges, as was the case for Minuartia dawsonensis, Silene menziesii and Thalictrum occidentale.

Of particular note in the vascular:plant flora of the Ecological Reserve are 19 rare species that currently are listed by ANHIC (2002) as having a provincial Rank in Alberta of S1 Elodea bifoliata (two-leaved waterweed); \$1S2 - Najas flexilis (slender naiad), Ruppia 
cirrhosa (widgeon-grass), Carex parryana var. parryana (Parry's sedge); $\$ 2$ - Botrychium multifidum var. intermedium (leather grape fern), Muhlenbergia asperifolia (scratch grass), Carex crawei (Crawe's sedge), Carex ?houghtoniana (Houghton's sedge), Cyperus schweinitzii (sand nut-grass), Drosera linearis (slender-leaved sundew), Lycopus americanus (American water-horehound), Veronica catenata (water speedwell), Hedyotis longifolia (long-leaved bluets), Aster pauciflorus (few-flowered aster), Shinneroseris rostrata (annual skeletonweed); S2S3 - Gentiana fremontii (marsh gentian); SU - Eleocharis ? elliptica (slender spike-rush), Chenopodium ?leptophyllum - narrowleaved goosefoot); and S3W - Asclepias ovalifolia (low milkweed). All but one of these provincially rare species previously have been reported in the several biophysical and other inventories of the Ecological Reserve and its immediate vicinity, notably by Bradley \& Bradley (1977), Fehr (1984), Cottonwood Consultants, Ltd. (1986), Wallis (1990), Anon (1998), Miejer (2001), Johnson (1992), Cotterill (2000) and ANHIC (2002). The present study includes one species that is new to the flora that is possibly rare, Chenopodium leptophyllum. However, there are identification problems with three of the above species: Chenopodium leptophyllum, Carex houghtoniana and Eleocharis elliptica. As well, there are records for six species that were reported from the area but were not repeated in the management plan (Anon 1998), the ANHIC records for tracked species data base (ANHIC 2002) or the Rare Vascular Plants of Alberta (Kershaw et al. 2001), and the presence of which require further confirmation: Elodea bifoliata, Najas flexilis Ruppia cirrhosa, Carex ?houghtoniana, Veronica catenata and Eleocharis ? elliptica 


\section{METHOD}

Alberta Sustainable Resource Development, Resource Data Branch contracted the author to conduct an inventory of the provincially rare vascular plants that had been reported from within the Ecological Reserve, with a view to confirming their locations, habitats, population sizes and potential habitat threats and management concerns, in order to provide a better understanding of their situation and requirements, to provide effective management for their protection and maintenance, and to provide a data base for documenting their occurrences.

Prior to and concurrent with the on-site survey, the above listed references and authorities were consulted to gain a familiarity with the natural features of the Ecological Reserve, and to form a "search image" for the various species; this was documented in the Preliminary Report (Macdonald June 2002). Previously reported records for provincially rare species were relocated by referring to the ANHIC (2002) data base for rare species, and where possible, to the several reports on the natural features of the Reserve (listed above) and through interviews with authorities familiar with the area (Harry Loonen and Patrick Porter of Alberta Sustainable Resource Development, Public Lands Division, Wainwright, and Cliff Wallis of Cottonwood Consultants, Ltd., Calgary). In many cases, these reports served as a guide to the discovery of new locations for the provincially rare species in the Reserve.

The 2002 on-site investigation rare vascular plant survey of the Wainwright Dunes Ecological Reserve was conducted by the author within the Reserve's boundaries, and occasionally just beyond them, over a 20 day period in the 2002 growing season in early summer (13 - 16 June), mid-summer (10 - 12, 14 - 21 July) and late summer (15 - 19 August). The survey of the rare vascular plants followed the general guidelines recommended by the Alberta Native Plant Council (Lancaster 2000). During this phase of the project the author conducted a survey of the apparent potential habitat situations for the various species as was possible in the time frame allowed within the study area. Due to their potential for supporting rare vascular plant species, particular attention was given to those habitats associated with the sand dune ridge blowout, seepage slope, 
patterned fen, lake backshore to offshore, and other wetlands. All species locations were accessed on foot to minimize damage to the sensitive terrain and vegetation, and allowed a more thorough survey along the routes between them. Rare species locations that were discovered were temporarily demarcated on the ground with flags so that the number of individuals could be accurately counted or estimated, and their extent measured and mapped, and individuals collected for verification, but only where the population would not be compromised. The results of the investigations were recorded on-site with the author's open file format, copies of which submitted to Alberta Sustainable Resource Development, Resource Data Branch office in Edmonton, and are retained on file at the Alberta Natural Heritage Information Centre, Alberta Community Development, Parks and Protected Areas Division offices in Edmonton. This information included all the data requirements of Alberta Environment's Site Description Form and ANHIC's Rare Native Plant Report Form. The following critical items were recorded: 1) rare species name; 2) location using a GPS unit (Eagle Explorer 1996) to determine latitude and longitude to degree and minute in thousandths and occasionally the 1927 datum Universal Transverse Mercator grid coordinates (UTM27) as well, and where accuracy was ensured, an aerial photograph was pierced and labelled at the exact or nearest accurate point; 3) site characteristics, including terrain type, substrate, moisture regime, aspect and slope; 4) associated community pattern, noting for each of the species the tree, tall shrub, low shrub and herb strata they occurred in, and their cover values in closure categories of $>95 \%, 75-95 \%, 50-75 \%, 20-50 \%, 5-20 \%, 1-5 \%$ and $<1 \% ; 5$ ) extent and number of individual plants by direct count or estimation as defined by the growth characteristics that appeared to be appropriate for enumerating the species, such as with discrete individuals, or leaf and inflorescence clusters along a rhizome chain; 6) phenology and growth condition of the rare plant species indicating stage of development, flowering or fruiting success; 7) present and potential threats to the habitat and the immediate vicinity; 8 ) notes on potential management concerns for the species; 9) notes on field identification characteristics that might aid future surveyors in locating the species; 10) map using planar view or oblique pictorial viewpoint indicating the species' extent in the area and the position of the pink surveyor's flagging tape that acts as a permanent reference to mark the location; 11) photograph to illustrate the plant growth, habitat detail and population extent; and 12) collection number of the rare and 
other associated species for future herbarium label preparation.

Following the on-site survey, the collected specimens were prepared by drying, then determined or confirmed by the author, inspected and confirmed by Bonnie M. Smith of the University of Calgary Herbarium, and sent to ANHIC in Edmonton for further confirmation by Patsy Cotterill at Alberta Community Development, Parks and Protected Areas. They were deposited for future reference in the herbaria of the University of Alberta (ALTA) and Alberta Community Development, Parks and Protected Areas (PP), both in Edmonton and of the University of Calgary (UAC) in Calgary. The on-site notes were clarified and corrected where necessary, and critical habitat information pertinent to the Ecological Land Survey Description forms of Alberta Sustainable Resource Development and the Rare Native Plant Report Information form of ANHIC were prepared, and the collected species data were summarized in the formatted presentation as species location reports for each of the rare species (see below). 


\section{SURVEY RESULTS}

The following brief summaries of the species location reports for each of the rare vascular plants species that previously have been reported within the Ecological Reserve or recently have been discovered as a result of the 2002 survey (see map). Their content includes the scientific and common names and provincial and global Ranks for the species in Alberta (Vujnovic \& Gould. 2002). A summary of the previously reported species location records and those that were resurveyed and newly discovered during the 2002 survey, comments on the species in the Reserve, apparent threats to the habitats and species locations, and management concerns for addressing the evaluation, monitoring and protection of the species within the Reserve. Further details for each species are provided in the appendices to this report.

\section{Botrychium multifidum var. intermedium (leather grape fern)-S2 G5T4?}

previous records: One species location with 20 plants was reported from an aspen forest by Cotterill in 2000 (ANHIC 2002).

survey results: Cotterill's 2000 location was refound, based on her UTM27, but the vegetation was a poplar forest with a clearing that was quite different from the aspen forest habitat of her report. No plants of this species were recorded in 2002.

comment: $\quad$ A thorough search of the reported location was conducted, but no rare species were recorded. The area also contained other northerly elements of regional interest.

habitat threats: No immediate threats to the species were evident, but there was possible past cutting in the forest.

management: 1) relocate species location

\section{Najas flexilis (slender naiad)-S1S2 G5}

previous records: One species location was reported by Fehr (1984) in a "beaver pond", probably at the Great Fen pond. No plant number information was available. The 1983 collection of Fehr is at PMAE (Provincial Museum of Alberta, Edmonton). 
survey results: The species was not recorded in above location in 2002.

comment: The Great Fen pond and most potential remaining ponds, streams and dugouts were searched, but no plants were recorded.

habitat threat: Pond drawdown due to drought conditions affected the available standing water for this aquatic species.

management: 1) find and confirm Fahr's specimen 2) relocate species location in moister climatic conditions

\section{Ruppia cirrhosa (widgeon-grass)-S1S2 G5}

previous records: One species location was reported by Fehr (1984) and cited by Cottonwood (1986) and Wallis (1990) from the vicinity of the north shore of David Lake where it occurred as a submergent aquatic in extensive marshes and open water of the saline lake. No plant number information was available.

survey results: This aquatic species was not recorded in above location or elsewhere in the Reserve in 2002.

comment: David Lake was dry due to the drought in 2002. The remaining channels, dugouts and water courses were searched, but no plants were recorded.

habitat threat: Extensive drawdown of the lake level due to drought conditions reduced the amount of standing water for this aquatic.

management: 1) confirm specimen 2) relocate species locations in moister climate conditions

\section{Elodea bifoliata (two-leaved waterweed) -S1 G4G5}

previous records: One species location was reported by Fehr (1984) as "Elodea canadensis" from "thicket pools, beaver pond". However, no location and no plant number information was available.

survey results: This rare aquatic species was not recorded in above location or elsewhere in the Reserve in 2002.

comment: This is a tentative occurrence in the Reserve. It possibly occurred in the Great Fen pond area. The Great Fen pond and most potential 
habitat in remaining ponds, streams and dugouts were searched for the species, but no individual plants were recorded.

habitat threat: The drawdown of the pond water level due to the drought conditions reduces the available standing water habitat for this aquatic species.

management: 1) confirm specimen 2) relocate species location in moister climatic conditions

\section{Muhlenbergia asperifolia (scratch grass)-\$2 G5}

previous records: One species location was reported by Wallis (1990) from theDavid Lake basin in "sandy lake upper shore". No plant number information was available.

survey results: During the 2002 survey there were 17 species locations discovered on the David Lake basin drawdown alkaline sandy offshore and nearshore meadows, of which 13 species locations were recorded within the Reserve boundaries, and four outside. 72780 plants were counted and estimated within the Reserve, and an estimated three million plants extended outside boundaries along a $700 \mathrm{~m}$ extent of David Lake's eastern shore.

comment: The species is successional on exposed alkaline sands of David Lake basin. It probably has additional species locations in the basin. It occurred in association with two provincially rare vascular plants, Aster pauciflorus (S2 G4) and Carex parryana (S1S2 G4T5).

habitat threat: Raising the water levels of the David Lake basin would drown the present species locations and reduce their extent to along the basin's shore.

management: 1) monitor known species locations 2) rediscover further species locations 3) monitor cattle grazing 


\section{Carex crawei (Crawe's sedge)-\$2 G5}

previous records: Four species locations were reported by Cottonwood Consulting, Ltd. (1986), and through collection records of Johnson \& Cotterill in 1992 and Cotterill \& Meijer in 2001 (ANHIC 2002) from at least four locations in the Great Fen and the David Lake northern backshore occurring in patterned fen and seepage slope grove habitats. The records of Cotterill and Meijer in 2001 reported "hundreds" from the David Lake northern backshore.

survey results: One species location was discovered outside the Reserve's boundaries on the David Lake northern backshore in a shrubby graminoid marsh, with 13 plants counted in very small area.

comment: The larger species location of the 2001 report was not relocated, although the area was searched, although it possibly was overlooked. There is high potential for plants to occur elsewhere around the David Lake basin. The backshore shrubby graminoid marsh habitat of the recently discovered population apparently was heavily cut and cleared in 1990s from forest and tall thicket habitat (H. Maull 2002). This species is associated with the provincially rare Gentiana fremontii (S2S3 G4).

habitat threat: The lowered water table in the habitat caused by the drought potentially has introduced retrogressive succession. The recent disturbance due to land clearing may have changed the associated community, but also may have improved the site conditions for this rare species.

management: 1) relocate previous species locations 2) monitor recent species locations 3) assess land clearance impact upon plant location

\section{Carex houghtoniana (Houghton's sedge) - 22 G5}

previous records: One species location was reported by Cottonwood (1986) from the Reserve's northwestern portion in a lightly grazed active blowout. No plant number information was available.

survey results: The species was not recorded in the apparent vicinity of the above 
location in 2002.

comment: Wallis (2002) was confident of this record, but it was not included by ANHIC in their rare plant species data base (ANHIC 2002). The similar Carex lanuginosa was discovered in an active blowout habitat in the same general area. The species location supported two rare species, Cyperus schweinitzii (S2 G5) and Shinneroseris rostrata (S2 G5?).

habitat threat: Sand erosion from the active blowout may expose the species roots.

management: 1) find and confirm specimen 2) relocate species location

\section{Carex parryana var. parryana (Parry's sedge)-S1S2 G4T4}

previous records: Three species locations were reported by Fehr (1984), Cottonwood Consultants, Ltd. (1986), Wallis (1990) and Meijer (2001) from the David Lake basin north offshore in wet saline meadows. Meijer reported observing 18 plants in the Reserve in 2001.

survey results: $\quad$ Ten species locations with 12621 plants were discovered within the Reserve, and four species locations with 11025 plants from outside the Reserve, totalling 23646 plants. The species habitats are occur in the David Lake basin near- to offshore drawdown zones as alkaline meadows and hummocky grasslands.

comment: $\quad$ There probably is a larger number of plants of this species along the southeastern and western portions of the David Lake basin. It occurred in association with the provincially rare Muhlenbergia asperifolia (S2 G5) and Aster pauciflorus (S2 G4).

habitat threat: The drought conditions are greatly drying the potential habitats in the inland sites. Reestablishment of the water levels of David Lake would drown plants.

management: $\quad$ 1) monitor known species locations 2) locate additional species locations elsewhere around David Lake's shore and in the peninsula meadows 


\section{Cyperus schweinitzii (sand nut-grass) - 2 G5}

previous records: Ten species locations were reported by Fehr (1984), Cottonwood Consulting, Ltd. (1986) and Johnson (2001) from seven locations in the Reserve. All occurred in active to semiactive sandy blowout habitats. No plant number information is available on these species locations.

survey results: $\quad$ There were 15 species locations discovered in the Reserve from two known general species locations, with a total population of 9123 plants. The habitats for these plants were semiactive to active blowout slopes of the dune ridges.

comment: The populations were not affected by the drought conditions. The species was associated with the provincially rare Shinneroseris rostrata (S2 G5?), Chenopodium ?leptophyllum (SU G5) and possibly Carex ?houghtoniana (S2 G5)

habitat threat: Wind erosion of sand in the blowout slopes may expose rhizomes of the plants, and excessive deposition may bury them.

management: 1) monitor species locations 2) monitor drought impacts on this dry site species

\section{Eleocharis ? elliptica (slender spike-rush)-SU G5T5}

previous records: One species location was reported by Fehr (1984), as Eleocharis compressa, to the west of Reserve's boundaries in a shrubby fen habitat, forming $0.5 \%$ in his community sample herb cover.

survey results: $\quad$ One possible species location was discovered at the Great Fen pond, on a beaver dam, with at least six plants.

comment: Macdonald collection requires confirmation. There are possible nomenclature problems where it was originally determined as Eleocharis compressa, but also may be this species if the potentially rare Eleocharis mamillata. It is associated with provincially rare plant Lycopus americanus (S2 G5)

habitat threat: The drought conditions have caused considerable drawdown of the pond water level, exposing considerable bare pond margin 
habitat. This may cause aggressive succession of other plants into its habitat. There may be minor trampling by wildlife and cattle.

management: $\quad$ 1) confirm specimen 2) refind and monitor species location

\section{Chenopodium ?leptophyllum (narrow-leaved goosefoot)-SU G5}

previous records: This rare species was unreported in the Reserve prior to 2002.

survey results: There were seven species locations with a total of 164 plants discovered in the southwestern portion of the Reserve on sandy grassland meadows and active sandy blowouts.

comment: The determination of the specimens of this species is tentative. It also may be the rare Chenopodium dissectum. It also was associated with the provincially rare Shinneroseris rostrata (S2 G5?) and Cyperus schweinitzii (S2 G5).

habitat threat: Wind erosion of sand in the blowout habitats may expose or bury existing species locations.

management: 1) confirm specimens 2) find additional species locations 3) monitor known species locations

\section{Drosera linearis (slender-leaved sundew) - \$2 G4}

previous records: Five species locations were reported by Fehr (1984), Cottonwood Consulting, Ltd. (1986) and Wallis (1990) from the Great Fen in shrubby graminoid fen and possibly in pond backshore tall thickets. The plant number information was limited to the comments "uncommon" or "occasional".

survey results: This species not rediscovered at above location during the 2002 survey.

comment: While the Great Fen supported ample suitable habitat in spite of drought conditions, no plants of this species were refound. All potential habitats and locations were thoroughly examined during several (portions of the 2002 growing season.

habitat threat: The continued drought conditions on the surface and ground water levels affected the condition of the fen habitats for the species. 
management: 1) refind species locations in Great Fen area 2) monitor species locations

\section{Gentiana fremontii (marsh gentian)-S2S3 G4}

previous records: Four species locations were reported by Fehr (1984), Cottonwood Consulting, Ltd. (1986) and Wallis (1990) from the northern offshore and peninsula of David Lake. The species occupied hummocky moist meadow and thicket fen, seepage fen and saline spring habitats. No information on the number of plants for this rare species was available.

survey results: Two species locations were discovered within the Reserve in the northern and southwestern backshore thickets of David Lake with one or two plants. As well, two species locations were recorded to the east of the Reserve boundary in the backshore shrubby marsh habitat, with a counted plant number of 326 individual plants and potentially a number of 1000 plants, based on the density within the narrow strip that was surveyed in the potential habitat.

comment: The habitat outside the Reserve boundaries on the north side of David Lake was disturbed in the past decade by severe cutting to improve grazing capability (Maull 2002). Fehr's specimen collection was discovered at the Alberta Parks and Protected Areas herbarium. The species is associated with the provincially rare species Carex crawei (\$2 G5).

habitat threat: The prolonged drought conditions have affected the groundwater quality and moisture regime of the habitat. As well, the cutting for site improvement opened the community cover and may have affected the plant numbers.

management: 1) monitor plant locations 2) find additional plant locations 3) resurvey hummock terrain and seepage fen sites

\section{Asclepias ovalifolia (low milkweed) - S3W G5?}

previous records: Three species locations were reported by Bradley \& Bradley (1977), 
Fehr (1984) and Cottonwood Consultants, Ltd. (1986) from sand hill grassland to the west of the Great Fen and elsewhere, but with no plant number information available.

survey results: There were 16 species locations discovered to the west of David Lake, west and north of the Great Fen, and in the Reserve's northern corner in rolling sand plain grassland, with 1317 plants counted within the Reserve.

comment: During the drought in 2002, the population produced flowering inflorescences; however the flowers were dried and had abscissed by mid-summer, and fruit development was arrested. This species is on the provincial Watch list (ANHIC 2002).

habitat threat: The drought conditions had an impact on the plant development. There may have been an impact by fire in the past, and there is a potential by wildlife and cattle trampling and grazing.

management: 1) monitor known species locations 2) discover new species locations in sandland situations

\section{Lycopus americanus (American water-horehound)-S2 G5}

previous records: Five species locations were reported by Bradley \& Bradley (1977), Fehr (1984) and Cottonwood Consulting, Ltd. (1986) from just northwest of David Lake in wetlands of the lake's shoreline in a sandland depression, and in a seepage fen. No information on the numbers of plants was given, other than a note of "uncommon here sparse".

survey results: There were 16 species locations discovered within the Reserve around the Great Fen pond, to the northeast of the Great Fen, on the northern David Lake backshore, and north of David Lake. These plant locations occurred along a drawdown beaver pond dam and along its shoreline marsh fringes, and also in lake backshore, seepage fen and lowland basin situations in tall thicket swamps. A total of 887 plants was counted within the Reserve, and 15 were counted at one site just outside its eastern boundary. 
comment: $\quad$ There is potential for a much larger population along the David Lake backshore in tall thicket habitats. It was associated with the provincially rare plant Gentiana fremontii (S2S3 G4).

habitat threat: The drawdown conditions of David Lake and the pond, stream and seepage water levels due to drought conditions may affect the plant habitats and numbers.

management: 1) monitor populations 2) refind previously reported species locations 3 ) determine impact of drought on beaver populations

\section{Veronica catenata (water speedwell)-S2S3 G5}

previous records: One species location was reported by Fehr (1984) from a "wet area near beaver lodge". This possibly was located at the Great Fen pond. No plant number information was available.

survey results: This species was not refound at the above location or elsewhere in the 2002 survey.

comment: The potential shoreline and wetland habitats were thoroughly searched, but no plants were found.

habitat threat: The pond shoreline has experienced considerable drawdown due to the prolonged drought conditions. This may create suitable potential habitat conditions for this species, but also may invite competition from weed invasion.

management: 1) find and confirm specimen 2) refind and monitor plant locations

\section{Hedyotis longifolia (long-leaved bluets)-S2 G4G5}

previous records: One species location was reported by Cottonwood Consultants, Ltd. (1986) $1 \mathrm{~km}$ west of the Great Fen in an aspen grove. No plant number information was available.

survey results: This species was not refound at above location during the 2002 survey.

comment: The aspen grove area indicated above was thoroughly searched, but the species was not found.

habitat threat: . There was past fire impact that modified the growth of the aspen 
community cover. There is at present a low trampling, grazing and fire potential.

management: 1) refind and confirm specimen 2) relocate and monitor plant location and numbers

\section{Aster pauciflorus (few-flowered aster)-S2 G4}

previous records: Two species locations were reported by Wallis (1990) and Miejer (2001) from the northern side of the David Lake basin to the east of the peninsula in "wet saline and subsaline lakeshores and edges of hummock meadows". There was limited plant number information that indicated a count of 18 plants in 2001.

survey results: Nine species locations were discovered within the Reserve on the northern side of the David Lake basin to the northeast, east and south of the peninsula. Within the Reserve a total of 551 plants were counted, and outside the Reserve on the eastern side of the lake there was an estimated over 6000 plants. In both cases they occurred in the drawdown lake basin's near- and farshore alkaline meadows and barren habitats.

comment: There is potential for a much larger population outside the Reserve along David Lake's southeastern portion. It was associated with the provincially rare plants Muhlenbergia asperifolia (S2 G5) and Carex parryana (S1S2 G4T4)

habitat threat: A rise in the water level of David Lake would drown the plants of this species.

management: 1) monitor known species locations 2) locate additional species locations elsewhere around David Lake's shore

\section{Shinneroseris rostrata (annual skeletonweed)-S2 G5?}

previous records: Three species locations were reported by Cottonwood Consultants, Ltd. (1986) and Johnson (1992) to the north of David Lake in sand dune blowout habitats. No information on plant numbers was available. 
survey results: There were 18 species locations discovered well to the west, northwest and north of David Lake in the sand ridge semiactive blowout habitats. A total of 257 plants was counted within the Reserve.

comment: There probably are additional species locations in those blowout habitats with Cyperus schweinitzii that were surveyed too early in growing season for this species to have been evident.

habitat threat: Wind erosion of blowout sand was observed to locally be advancing over this plant species' locations.

management: 1) monitor known populations 2) discover additional species locations 3) monitor drought conditions and its impact on seed production and germination success

As well, there are two provincially rare vascular plant species that had been reported from the Reserve by Fehr (1984) and Cottonwood Consultants, Ltd. (1986) and were listed in the compilation flora in the Reserve's management plan (Anon 1998), but which should be withdrawn, Danthonia californica Bol. (California oat grass) and Carex rostrata J. Stokes (beaked sedge). In both cases, the nomenclature used was based on that appearing in the 1983 edition of Flora of Alberta, which has since been revised. Wallis (2002) concurred with this recommendation. In the case of the Danthonia californica, the literature now distinguishes the smaller Danthonia intermedia from the larger Danthonia californica, and only the former has been recorded from the Reserve. In the case of Carex rostrata, the literature recognizes two varieties, the rare var. rostrata and the more common var. utriculata (F. Boott) L. Bailey which now has species status as Carex utriculata F. Boott (NatureServe 2003), and only the latter has been recorded from the Reserve. 


\section{DISCUSSION}

During the 2002 survey of rare vascular plants in the Wainwright Dunes Ecological Reserve, the following 19 species were investigated (the scientific and common names, and provincial conservation Rank in Alberta are given):

Elodea bifoliata ( two-leaved waterweed)-S1 G4G5

Najas flexilis (slender naiad)-S1S2 G5

Carex parryana var. parryana (Parry's sedge)-S1S2 G4T4

Aster pauciflorus (few-flowered aster)-S2 G4

Botrychium multifidum (leather grape fern)-S2 G5T4?

Ruppia cirrhosa (widgeon-grass)-S2 G5

Muhlenbergia asperifolia (scratch grass)-S2 G5

Carex crawei (Crawe's sedge)-\$2 G5

Carex ?houghtoniana (Houghton's sedge)-\$2 G5

Cyperus schweinitzii (sand nut-grass)-\$2 G5

Drosera linearis (slender-leaved sundew)--S2 G4

Lycopus americanus (American water-horehound)-S2 G5

Veronica catenata (water speedwell)-S2 G5

Hedyotis longifolia (long-leaved bluets)—S2 G4G5

Shinneroseris rostrata (annual skeletonweed)-S2 G5?

Gentiana fremontii (marsh gentian)-S2S3 G4

Eleocharis ?elliptica (slender spike-rush)-SU G5T5

Chenopodium ?leptophyllum (narrow-leaved goosefoot)-SU G5

Asclepias ovalifolia (low milkweed)-S3W G5?

Ten of these species were relocated and additional locations were discovered within the Reserve and its immediate vicinity, as follows (these plants are grouped according to their provincial Rank in Alberta; numbers indicate the number of new species locations and number of plants occurring within the Reserve boundary, and, indicated in brackets 0 , for those occurring outside the boundary):

S1S2 Carex parryana var. parryana (Parry's sedge)-10 species locations with 12 
621 plants (4 species locations with 11025 plants)

S2 Muhlenbergia asperifolia (scratch grass)-3 species locations with 72780 plants (4 species locations with 3000000 plants)

S2 Carex crawei (Crawe's sedge)-0 species location with 0 plants (1 species locations with 13 plants)

S2 Cyperus schweinitzii (sand nut-grass) - 15 species locations with 9123 plants (none)

S2 Lycopus americanus (American water-horehound)- 16 species locations with 887 plants (1 species location with 15 plants)

S2 Aster pauciflorus (few-flowered aster)-9 species locations with 551 plants (1 species location with 6000 plants)

S2 Shinneroseris rostrata (annual skeletonweed)-18 species locations with 257 plants

S2S3 Gentiana fremontii (marsh gentian)-2 species locations with 3 plants (4 species locations with 184 (possibly over 1000 ) plants)

SU Eleocharis ?elliptica (slender spike-rush)-1 species location with 6 (?) plants (none)

SU Chenopodium ?leptophyllum (narrow-leaved goosefoot) -7 species locations with 164 plants (none)

S3W Asclepias ovalifolia (low milkweed) - 16 species locations with 1317 plants (none)

Six of these species (Muhlenbergia asperifolia, Aster pauciflorus, Carex parryana var. parryana, Gentiana fremontii, Lycopus americanus, Carex crawel) occurred within the Ecological Reserve as concentrations in the near- to offshore habitats of the David Lake basin near the peninsula's southern tip and along its eastern side, and outside of the Reserve along the basin's southeastern side. Three of these species occurred in association with the sand ridge blowout habitats at several locations within the Reserve (Cyperus schweinitzii, Shinneroseris rostrata, Chenopodium ?leptophyllum). Two of these species occurred in association with the wetland habitats of beaver pond dams and shores, and actively flowing springs (Lycopus americanus, Eleocharis ?elliptica). One of these species occurred in shrubby grasslands on the rolling sand plains (Asclepias ovalifolia). 
Eight of the rare vascular plant species that had been reported in previous studies (Fehr 1984, Cottonwood Consultants, Ltd. 1986, Cotterill 2000) could not be relocated within the Reserve, and hence, no new locations or information on the number of plants are available for them, as follows (plants are grouped according to their provincial Rank in Alberta; numbers indicate number of former species locations and populations):

S1 Elodea bifoliata (two-leaved waterweed) - 1 former species location with unknown number of plant numberss

S1S2 Najas flexilis (slender naiad) - 1 former species location with unknown number of plants

S2 Botrychium multifidum (leather grape fern) - 1 former species location with unknown number of plants

S2 Ruppia cirrhosa (widgeon-grass) - 3 former species locations with unknown number of plants

S2 Carex ?houghtoniana (Houghton's sedge) - 1 former species location with unknown number of plants

S2 Drosera linearis (slender-leaved sundew) - 5 former species locations with unknown number of plants

S2 Veronica catenata (water speedwell) - 1 former species location with unknown number of plants

S2 Hedyotis longifolia (long-leaved bluets) - 1 former species location with unknown number of plants

One of these species was reported from the David Lake basin (Ruppia cirrhosa), two from a "beaver pond", possibly that to the southeast of the Great Fen (Elodea bifoliata, Najas flexilis), one from an aspen grove west of the Great Fen (Hedyotis Iongifolia), one from the Great Fen itself (Drosera linearis), one from aspen forest north of David Lake (Botrychium multifidum var. intermedium), one from a sand ridge blowout in the Reserve's northwestern portion (Carex ?houghtoniana), and one which had no reported location (Veronica catenata). The considerable drawdown condition of David Lake due to the prolonged drought, rendering it virtually without standing water except for local dugouts, left no habitat for the Ruppia cirrhosa, and similarly the drawdown of the Great Fen pond greatly reduced the aquatic habitat for the Elodea bifoliata and Najas flexilis. 
The aspen grove and poplar forest habitats of the Hedyotis longifolia and the Botrychium multifidum were diligently searched, but no plants found, perhaps due to unsuitable growth conditions for the species caused by the drought conditions in the former case, but possibly due to an incorrectly reported location in the latter case. A similarly diligent search of the patterned fen habitat in the Great Fen for the Drosera linearis did not rediscover any plant locations, although ample suitable habitat was available. The Veronica catenata had no reported location, but was unsuccessfully searched for in suitable habitats. The sand ridge blowout habitats at the reported general location for the Carex ?houghtoniana were searched; however, since only a similar, but common, species (Carex lanuginosa) was discovered, the original report requires confirmation (Cottonwood Consultants, Ltd. 1986). 


\section{HABITAT THREATS}

The habitat threats to the locationsd and habitats of the provincially rare vascular plant species generally fall into the following four categories:

\section{Xeric conditions of prolonged drought:}

The drought conditions over the previous three years have resulted in the marked drawdown of David Lake, the Great Fen pond and most of the other water bodies in the Reserve. This has resulted in at least the temporary loss of much significant aquatic habitat, and possibly also the permanent loss of three aquatic species from the Reserve's flora, Elodea bifoliata, Najas flexilis and Ruppia cirrhosa. However, the persistence of a resilient seed bank or other propagule mechanism in these drained situations may allow the species to reappear in a moister climatic period. Additionally, the dry conditions have contributed to the loss of beaver activity in several of the stream channels and ponds, resulting in the degradation of the dams and a further exacerbation of the drawdown situation. This has affected the known plant numbers of three lowland species, Lycopus americanus, and possibly Eleocharis ?elliptica and possibly Veronica catenata. However, this drawdown situation has extended the shoreline fringe habitat that may provide additional opportunities for the above species to increase their numbers, at least until the water levels are restored. The greatly lowered groundwater levels in lowland sites has stressed the associated swamp and lowland forest, and thicket and marsh communities with their rare species Botrychium multifidum var. intermediumand Lycopus americanus, and notably also the patterned fen communities in the Great Fen with its species location of the provincially rare Drosera linearis. The groundwater and surface water flow patterns in the seepage slope sites around David Lake have resulted in a notable drying of the ground surface, possibly initiating a change in retrogressive succession and affecting the plant numbers of Gentiana fremontii, Carex parryana, Carex crawei and Lycopus americanus. The further dessication of the already dry grassland habitats was observed to interfere with the inflorescence development of at least one species, Asclepias obtusifolia. However, it was 
apparent that those species that normally were associated with very dry habitats, Cyhperus schweinitzii and Shinneroseris rostrata, did not display major reduction in their anticipated normal growth due to the prolonged drought.

\section{Cessation of drought causing flooding of sites:}

The considerable drawdown in David Lake caused by the prolonged drought has resulted in an extensive plain of exposed alkaline sand that has provided ample habitat conditions for several rare plants to succeed over and greatly expand their populations, notably Muhlenbergia asperifolia, Aster pauciflorus and Carex parryana. However, when the drought ends and the water level is restored in the lake, these populations will be inundated and will be unable to grow and produce inflorescences. Nevertheless, these species all produce perennial rhizomes that may well be adapted to surviving such a situation, and may rebound in later lower water levels. Additionally, in the case of the grass Muhlenbergia asperifolia, the inflorescences which produce a profuse number of seeds, become detached from the plants, and blow across the lake plain to be deposited in the backshore sites around the periphery of the lake; these may well provide a seed bank for the growth of plants around the lakeshore in years of higher water levels.

\section{Grazing and trampling:}

Grazing by the reduced size of the cattle herds appeared to be localized around the David Lake basin and its immediate vicinity. The grazing pattern did not appear to directly affect any of the populations of rare plants, since they generally were not vigorous or palatable enough to be a targeted forage species. As well, the grazing patterns of the cattle tended to remove about 50 to $75 \%$ of the vegetation cover, but only within relatively narrow swaths approximately one or two metres wide through the associated communities. This often left well over $80 \%$ of the potential habitat and associated plant community ungrazed. Several cattle and game trails were recorded as passing through, or adjacent to, the general locations for and habitats of several of the provincially rare species, such as Lycopus americanus, Asclepias obtusifolia, Carex crawei 
and Gentiana fremontii, with some very incidental grazing along either side of the trails.

\section{ATV disturbance:}

Only one instance of ATV ("quad") use within the Reserve was recorded, where a year-old track crossed one of the sand dune ridges, initiating only a local exacerbation of blowout erosion and deposition. However, this track did not directly impinge upon populations of the nearby dune blowout with its provincially rare species, Cyperus schweinitzii or Shinneroseris rostrata. 


\section{MANAGEMENT CONSIDERATIONS}

The following management concerns should be addressed in future activities leading toward the protection of the rare vascular plant species in the Reserve:

1. Monitoring known rare plant populations:

The prolonged regional drought conditions undoubtedly impose stresses upon the habitats and growth behaviour of the provincially rare plant species in the Reserve. This has resulted in changes to the number of individual plants that may be evident from year to year. For example, of the notable report of "hundreds" of Carex crawei plants occurring in the David Lake backshore tall thickets (Cotterill \& Majeir 2001), not one plant could be found in 2002. On the other hand, the populations of Cyperus schweinitzii appeared to be thriving at their locations, which may be understandable since they are, after all, species adapted to xeric sand habitat species. Shinneroseris rostrata is an annual that is fully dependent upon the production and germination of its seed bank for survival from year to year, and while the drought conditions may be anticipated to act against this species, the plant numbers that were recorded, indicated that, in spite of the little rain over the previous summer and winter, they must have been able to readily germinate, or at least take advantage of snow banks along the blowout slope crests.

2 Relocating previously reported rare plant populations:

Several of the species locations of provincially rare vascular plants could not be relocated during the 2002 survey, either because the drought conditions caused them to not appear in their assumed habitats or because the original reports had insufficient detail for relocating them. A further survey project, perhaps during a wetter year, should attempt to relocate several of the species, such as Drosera linearis from the Great Fen, Gentiana fremontii from the hummocky grasslands of the David Lake peninsula, Carex parryana from the grassland depressions at the base of the peninsula, Carex crawei from the northern backshore of David Lake, Hedyotis longifolia from the aspen grove west of David Lake, and Botrychium 
multifidum from the forests north of David Lake.

3. Relocating and confirming rare vascular plant determinations:

Several of the rare plant occurrences in the Ecological Reserve could not be relocated. Since the original claims probably are based on the determinations of voucher collections, these collections should be sought and confirmed to ensure that they are correctly determined, and if so, the collectors should be contacted to gather further information about their locations if such information can be retrieved after the ensuing two decades. This would be applicable for the following species which could not be relocated or for which the record may require the substantiation or redetermination: Elodea bifoliata, Najas flexilis, Botrychium multifidum, Ruppia cirrhosa, Carex ?houghtoniana and Veronica catenata.

4. Discouraging ATV use and trampling within the sensitive habitats: What probably was an unauthorized ATV use in sensitive habitats within the Reserve boundaries was noted only once during the 2002 survey. Nevertheless, there is modest vulnerability to such incursions from the various unmonitored access points around the entire area. Currently, the local ranchers stewarding the Reserve do keep watch for such incursions, and restrict their own use to the periphery of the Reserve and to the interior access roads. With a combination of the concentrations of several provincially rare plants in the blowouts, such as Shinneroseris rostrata and Cyperus schweinitzii, and the lure of illicit sand dune recreational opportunities afforded by the same blowouts, any illicit vehicular use potentially would result in great and lasting damage to the species locations. Any such use should be monitored and an enforcement and awareness program should be considered if the problem warrants it. 


\section{REFERENCES}

ANHIC. 2002. Alberta Natural Heritage Information Centre Data Base, Records for Tracked Species Occurrences - 26 May 2002. Alberta Natural Heritage Information Centre, Alberta Community Development, Edmonton.

ANHIC. 2003. Alberta Natural Heritage Information Centre Data Base, searched 28 February, 2003. Alberta Community Development, Parks and Protected Areas Division, Edmonton $\mathrm{AB}$.

Anon. 1998. Wainwright Dunes Ecological Reserve Management Plan. February 1998. Alberta Agriculture, Food and Rural Development, and Alberta Environmental Protection, Edmonton.

Argus, G.W. and Pryer, K.M. 1990. Rare Vascular Plants in Canada: our natural heritage. Canadian Museum of Nature, Ottawa.

Bradley, L. and C. Bradley. 1977. Aspen Grove resource assessment: Wainwright area. Parks Planning and Design Branch, Alberta Recreation, Parks and Wildlife, Edmonton. Cottonwood Consultants, Ltd. 1986. The Proposed Wainwright Ecological Reserve-A Biophysical Overview. Alberta Recreation and Parks, Edmonton.

Fassett, N.C. 1957. A Manual of Aquatic Plants. The University of Wisconsin Press, Madison and London. ix $+405 \mathrm{pp}$.

Fehr, A. 1984. Wainwright Study Area: Biophysical Inventory. Natural Areas Program, Public Lands Division, Alberta Energy and Natural Resources, Technical Report No. t/65, Edmonton $A B$.

Fernald, M.L. 1950. Gray's Manual of Botany: eighth edition - illustrated. American Book Company, New Yoik NY. Ixiv + 1632 pp.

Flora of North American Editorial Committee. 1993. Flora of North America: Volume 2 Pteridophytes and Gymnosperms. Oxford University Press, New York, Oxford. xvi +475 $\mathrm{pp}$.

Gleason, H.A. and Cronquist, A. 1991. Manual of Vascular Plants of Northeastern United States and Adjacent Canada - Second Edition. The New York Botanical Garden, Bronx NY. Ixxv + $910 \mathrm{pp}$.

Kershaw, L., J. Gould, D. Johnson and J. Lancaster. 2001. Rare Vascular Plants of Alberta. University of Alberta Press, Edmonton AB. xliv +484 pp. 
Lancaster, J. 2000. Guidelines for Rare Plant Surveys. Alberta Native Plant Council. Macdonald, Ian D. June 2002. Rare Vascular Plant Survey of the Wainwright Dunes

Ecological Reserve - Preliminary Report. For Alberta Sustainable Resource

Development, Edmonton AB.

Miejer, M. 2001. Survey of Rare Plant Element Occurrences in the Central Parkland Natural Subregion (includes Rare Native Plant Forms), open file, ANHIC, Edmonton. Moss, E.H. 1959. Flora of Alberta. University of Toronto Press, Toronto. vii +546 pp. Moss, E.H. 1983. Flora of Alberta: second edition (revised by J.G. Packer). University of Toronto Press, Toronto. $x \mathrm{iii}+687 \mathrm{pp}$.

Muenscher, W.C. 1972. Aquatic Plants of the United States. Cornell University Press, Ithica and London. $x+374 \mathrm{pp}$.

NatureServe. 2003. NatureServe: an online encyclopedia of life (web application) Arlington VA. (accessed January 2003)

Pearson Timberline Forestry Consultants. 1993. Wainwright Dunes Ecological Reserve:

Vegetation Change / Disturbance Assessment. Alberta Environmental Protection, Edmonton $A B$.

Scoggan, H.J. 1978. The Flora of Canada-Part 2: Pteridophyta, Gymnospermae, Monocotyledoneae. Publications in Botany No. 7(2). National Museum of Natural Sciences, National Museums of Canada, Ottawa ON. pages 93 - 545.

Scoggan, H.J. 1979. The Flora of Canada - Part 4: Dicotyledoneae (Loasaceae to

Compositae). Publications in Botany No. 7(4). National Museum of Natural Sciences,

National Museums of Canada., Ottawa ON. pages 1117 - 1711.

Struwe, L. and V.A. Albert (editors). 2002. Gentianaceae: systematics and Natural History. Cambridge University Press, Cambridge. $x+652 p$.

Voss, E.G. 1967. A vegetative key to genera of submersed and floating aquatic vascular plants of Michigan. The Michigan Botanist 6: 35 - 50.

Wagner, W.H. and F.S. Wagner. 1992. OPHIOGLOSSACEAE C. Agardh $\square$ Adder's-tongue

Family - BOTRYCHIUM Swartz subg. SCEPTRIDIUM (Lyon) R.T. Clausen sect.

HIEMOBOTRYCIUM W.H. Wagner, Novon 2:267. IN Flora of North American Editorial

Committee. 1993. Flora of North America: Volume 2 - Pteridophytes and

Gymnosperms. Oxford University Press, New York, Oxford. xvi + 475 pp.

Wallis, C. 1990. Reconnaissance Survey of Saline Wetlands and Springs in the Grassland - 
Parkland Region of Eastern Alberta. Cottonwood Consultants, Ltd., Calgary and Alberta Lands, Forestry and Wildlife (Natural and Protected Areas), for World Wildlife Fund Canada and Alberta Forestry, Lands and Wildlife, Prairie for Tomorrow, Edmonton.

Vujnovic, K. and J. Gould. 2002. Alberta Natural Heritage Information Centre Tracking and Watch Lists - Vascular Plants, Mosses, Liverworts and Hornworts - June 2002. Alberta Community Development, Parks and Protected Areas Division, Edmonton AB.

\section{INTERVIEWS AND COLLECTION RECORDS}

(personal communications with lan D. Macdonald except where otherwise noted) Cotterill, Patsy. 2000. Collection Records - 15 July. Cotterill, Patsy. 2003. Personal Communications - 7 March. Cotterill, Patsy and M. Meijer. 2001. Collection records - 31 July. Johnson, Derek. 1992. Collection Records - 29 July. Macdonald, Ian D. 2002. On-site Survey Records - 12 - 16 June, 10 - 21 July, 15 - 19.

August, available at Alberta Natural Heritage Information Centre, Edmonton. Maull, Hilson. 2002. Personal Communications - 17 August.

Wallis, Cliff. 2002. Personal Communications - 3 September 2002. 


\section{APPENDIX 1}

Botrychium multifidum (S.G. Gmelin) Rupr.

var. intermedium (D.C. Eat.) Farw.

- leather grape fern-OPHIOGLOSSACEAE

This low woodland and field fern has a provincial Rank of $\mathbf{S 2}$ in Alberta and a global rank of G5T4? (Vujnovic \& Gould 2002, ANHIC 2002). NatureServe (2003) indicated that the authorities for this species are (Gmel.) Trev., and that its other common name is "leathery grape fern". This is one of the more readily recognizable grape ferns in the province. Like the one other large-leaved grape fern that occurs in the province, Botrychium virginianum (Virginia grape fern), its sterile blades are relatively large (10 to $25 \mathrm{~cm}$ wide, 15 to $35 \mathrm{~cm}$ long) and are divided two to three times; however, it differs in that its petiole attachment is near the base of the stalk, the blades are leathery, and it persists through the winter (Moss 1983, Scoggan 1978). It occurs in Alberta as the var. intermedium (D.C. Eat.) Farw. (Moss 1983), but the nomenclatural treatment of Wagner \& Wagner (1993) in the Flora of North America did not recognize this variety.

This species extends across central North America in the boreal and northern temperate zones between Alaska and Newfoundland, and south to California to West Virginia (Wagner \& Wagner 1993). It is rare in three provinces, including Alberta, Prince Edward Island and Newfoundland (as well as Labrador), and in ten states (NatureServe 2003). Within Alberta it occurs at 34 known locations, extending between Grande Prairie and east southeast to just east of Edmonton, including an isolated location north of Lake Athabasca (ANHIC 2003, Kershaw et al. 2001). The location from the Wainwright Dunes Ecological Reserve was not mapped in the Rare Vascular Plants of Alberta (Kershaw et al. 2001) or listed in Fehr 1984, but the Element Occurrence Data Base of ANHIC (2003) listed one species location north of David Lake, discovered by Patsy Cotterill and others in July 2000. The apparently exact UTM27 grid location within the Ecological Reserve was relocated during the present survey; however, no plants were rediscovered there or in its general vicinity. Further, the anticipated habitat was not an aspen forest as indicated in Cotterill's specimen label, but rather was a balsam poplar forest with an opening, both of which supported a rich complement of northerly species in the gently undulating mesic 
sand plain that was somewhat removed from the base of the low bluff slope well north of the present-day David Lake shore. Nevertheless, both the closed forest and opening were surveyed to ascertain their Ecological Land Site characteristics.

Patsy Cotterill (2000) reported that she had recorded 20 plants in the area. In this species, the leaves should persist throughout the year with new leaves developing by early to mid-summer, and the fruiting heads should have developed by mid-summer. However, no plants at all were observed during the 2002 survey, and Cotterill (2003 personal communication) confirmed that the surveyed habitat did not conform to her recollection of her species location.

The habitat that was surveyed during 2002 was a mesic, gently rolling sand plain with a balsam poplar forest and an adjacent shrubby clearing, both of which supported a complement of northerly herb species. The forest had a semiclosed to closed tree cover of Populus balsamifera, a semiclosed to semiopen tall shrub cover of Salix bebbiana, Prunus virginiana, Corylus cornuta, and Amelanchier alnifolia (saskatoon), and low shrub cover of Cornus stolonifera and Symphoricarpos occidentalis, and a semiopen to semiclosed herb cover of Aralia nudicaulis, Rubus pubescens, Oryzopsis asperifolia, Viola canadensis, Lysimachia ciliata (fringed loosestrife), Thalictrum ?occidentale, and other rich lowland forest species. The clearing supported a semiclosed to locally open tall shrub cover of Prunus virginiana, Amelanchier alnifolia and Corylus cornuta, semiclosed low shrub cover of Rosa acicularis, Symphoricarpos occidentalis and Rubus idaeus, and a semiclosed herb cover of Schizachne purpurascens, Oryzopsis asperifolia, Galium boreale and others.

Habitat threats to the species could not be determined at this time; however, none were apparent at the location that was surveyed in 2002 . The past cutting that formed the clearing may have imposed some impact on the site conditions for the species. No signs of grazing were evident.

Management considerations must first be to relocate the plants, which should be expected still to be standing since they generally tend not to be ephemeral nor 
intermittent in their yearly growth and are tall enough to be relatively obvious.

Ecological Land Survey Site Description and ANHIC Rare Native Plant Report Information for Botrychium multifidum in the Wainwright Dunes Ecological Reserve

ECOLOGICAL LAND SURVEY SITE DESCRIPTION

Exposure Type

Flood Hazard

Soil Drainage

Perviousness

Site: Macro

Site: Meso

Site: Micro

Site: Surface Shape

Ecological Moisture Regime

Nutrients

Successional Status: 1

Successional Status: 2

Disturbance Factors not apply

no hazard (1)

moderately well drained (4)

moderately (2)

plain (7)

level (7)

straight (1)

straight (1)

mesic (5)

?meso (3)

?mature edaphic climax (6)

not apply

none

ANHIC RARE NATIVE PLANT REPORT

Phenology: vegetative

Phenology: inflorescence

Phenology: sporulating

Habitat Threats:

Management Considerations no information (?early to mid-summer)

no information (?mid- to late summer)

no information (?mid- to late summer)

no information

refind population 


\section{APPENDIX 2}

Najas flexilis (Willd.) Rostk. \& Schmidt.

\section{- slender naiad-NAJADACEAE}

This submergent and rooted, annual aquatic herb of pond and stream habitats has a provincial Rank of S1S2 in Alberta, and a global Rank of G5 (Vujnovic \& Gould 2002, ANHIC 2002). It is the only member of its genus in Alberta, and has a rooted erect stem with many alternating branches, although they often are broken, and with narrow linear leaves in what appear to be whorls of four, that actually are subopposite pairs. It has single, very simple, tiny flowers in the axils of the lower of the subopposite leaf pairs, and single pairs of small, elliptic achenes. The bushy appearance of this species, particularly in late season, allows it to resemble some of the small-leaved Potamogeton species, and perhaps even the rare Elodea bifoliata. However, it differs from the former in having narrow, serrate leaves that have notably and abruptly broader, clasping bases and no stipules, and from the latter in not having simple opposite leaf pairs (Moss 1983, Fassettt 1957. Muenscher 1972, Voss 1967).

This species occurs across most of North America, is rare in Alberta, Saskatchewan and Prince Edward Island, and in two states, and is may have been extirpated from one state (NatureServe 2003, Kershaw et al. 2001). In Alberta it has been recorded from seven locations the Parkland and adjacent southwestern Boreal Natural Regions (ANHIC 2003). The Wainwright Dunes Ecological Reserve appears to be the only known location in the eastern portion of the Parkland Natural Region, and it was first reported in the Ecological Reserve through a collection of A. Fehr in 1983, but was not listed in his list of the Reserve's flora (Fehr 1984). This collection apparently was taken from the large pond on the southeastern side of the Great Fen (ANHIC 2002), northwest of David Lake. However, the 2002 survey of the reserve did not rediscover any plants in this large pond or in other suitable wetland sites.

There was no information on the number of individuals provided in the collection data for the single known specimen from the reserve. 
The wetland habitat of the "beaver pond" that the collection label for this species apparently refers to has experienced considerable drawdown due to the prolonged regional drought conditions between 2000 and 2002. Some standing water still occurred in the central portions of the wetland basin; however, the extent of the exposed barren soils along the drawdown fringe was very great. The survey of the pond area during the 2002 survey discovered several species of Potamogeton, Potamogeton pectinatus, Potamogeton zosteriformis (flat-stemmed pondweed) and Lemna minor (common duckweed), but little else in the aquatic flora. The species' persistence here may require beaver activity to maintain the dam that keeps the water level high.

The major habitat threat to this species within the reserve is the considerable and long term drawdown situation in the beaver pond basin where it was reported over 20 years ago. The regional drought conditions probably have greatly worsened this situation, and probably also has resulted in the apparent loss of the active beaver population to maintain the dams and ponds.

Management considerations should be to resurvey the beaver pond at the southeastern end of the Great Fen, and the other beaver ponds in the reserve, in hope of rediscovering the species. Such surveys in the mid-summer season should prove more productive if the species still persists. The actual collection location of the known specimen may be in doubt, since, while this may be just a clerical error, the latitude / longitude coordinates on the specimen label indicated a point in the sandland about 2 $\mathrm{km}$ due west of David Lake where no pond feature exists. As well, the species was not included in Fehr's otherwise meticulously inclusive general species list for the reserve and its vicinity and was not repeated in the compilation list in the Ecological Reserve's management plan (Anon 1998). 
Ecological Land Survey Site Description and ANHIC Rare Native PIant Report Information for Najas flexilis in the Wainwright Dunes Ecological Reserve

ECOLOGICAL LAND SURVEY SITE DESCRIPTION

Exposure Type

not apply

Flood Hazard

not apply

Soil Drainage

very poorly (7)

Perviousness

slowly (3)

Site: Macro

plain (7)

Site: Meso

level (7), depression (6)

Site: Micro

straight (1)

Site: Surface Shape

straight (1)

Ecological Moisture Regime

hydric (9)

Nutrients

?permesotrphic (4), ?mesotrophic (3)

Successional Status: 1

pioneer (1)

Successional Status: 2

not apply

Disturbance Factors

draining (8)

ANHIC RARE NATIVE PLANT REPORT

Phenology: vegetative

no information

Phenology: reproductive - inflorescence

no information (?June to July)

Phenology: reproductive - flower

no information (?July)

Phenology: reproductive - fruit

no information (?August)

Habitat Threats

pond water level

Management Considerations

refind and monitoring populations 


\section{APPENDIX 3}

\section{Ruppia cirrhosa (Petagna) Grande}

\section{-widgeon-grass-RUPPIACEAE}

This aquatic herb of saline and alkaline lakes, ponds and ditches has a provincial Rank of S1S2 in Alberta, and a global Rank of G5 (Vujnovic \& Gould 2002, ANHIC 2002). Its leaves are 5 to $20 \mathrm{~cm}$ long and less than $0.5 \mathrm{~mm}$ wide in fan-like groups, with sheathing, scarious-margined stipules that are $5 \mathrm{~cm}$ to $20 \mathrm{~cm}$ long, with very un-Potamogeton-like inflorescences consisting of pairs of tiny flowers with no petals and two stamens borne on a spadix from the upper leaf axils, with fruits developing at the tips of four branches in umbel-like clusters atop distinctly coiled culms. While this species is distinctive in its fertile state, it is difficult to differentiate from the similar Potamogeton pectinatus in its vegetative state, and may initially also be mistaken for Potamogeton filiformis (threadleaved pondweed). Voss (1967) presented several useful vegetative characteristics to aid in its recognition and to separate it from the genus Potamogeton, as follows: sheath with no free ligule at summit, i.e., the stipule wholly adnate to leaf blade, merely rounded at summit (not with a short ligule-like extension of the free stipule at the summit, i.e., the stipule only partly adnate, as in Potamogeton); leaf blade terete (not flattened); fruit stalked in an umbel-like arrangement on a spiraled and elongating limp peduncle (not sessile or subsessile in a spike with a straight stiff peduncle). The genus formerly was treated as one species, Ruppia maritima L. (formerly called Ruppia occidentalis S. Wats.); however, recent taxonomic treatment has restricted that species name to apply to maritime coastal plants, while the name Ruppia cirrhosa (formerly called Ruppia spirillis L. ex Dumort) to apply to continental western North American plants.

This is a circumpolar species that occurs in the western half of North America from the Arctic southward into Central America. It is rare in Alberta, Manitoba and Northwest Territories, and also in two of the western states, and may have been extirpated from one state (NatureServe 2003, Kershaw et al. 2001). In Alberta it has been reported from six known locations in the southwestern corner of the Grassland Natural Region and the vicinity of Edmonton in the Parkland Natural Region (ANHIC 2003). Its only reports from the eastern portion of the Parkland Natural Region were those of Fehr (1984) and 
Cottonwood Consultants, Ltd. (1986) who reported it from the David Lake basin at the peninsula, apparently in the then standing waters of the lake. This species was not relocated during the 2002 survey of the Ecological Reserve. The extensive drawdown conditions in the entire David Lake basin have rendered the site no more than a big salty parking lot. The entire chain of dugout channels in the basin created by Ducks Unlimited were examined, but no water at all remained in them, and while the two larger dugouts in the basin held some water, no aquatic plants of any sort were observed there.

Additionally, the dugout along the Reserve's eastern boundary north of David Lake, and that to the east of the Reserve boundary on the northeastern backshore of David Lake, were surveyed for populations of this species, but none were found.

No information on the number of individuals was available in the several reports for this species' occurrence in the Ecological Reserve, and no plants were relocated during the present survey. It may be that the species has been thoroughly decimated by the drought conditions, and possibly it is even extirpated from the Reserve's flora.

The habitat for this species was indicated by Fehr (1984) to be "submergent" in the then standing waters of David Lake, and the report of Cottonwood Consultants, Ltd. (1986) indicated it to be in "extensive marshes and open water" of the lake, offshore from the central eastern side of the David Lake peninsula. Both of these surveys were conducted in relatively wet years with David Lake being at a high water level. However, the present survey was conducted in a period of extreme drought, and no standing water at all was recorded except in the larger dugouts which had very dark waters from cattle excrement leachate. The relatively cleaner waters of the dugout located along the Reserve's eastern boundary to the northeast of the lake's backshore, and of the several ponds in the interior of the Reserve, did not have: this species, although several species of Potamogeton were noted, including the similar Potamogeton pectinatus, and particular care was taken during the 2002 survey in their determination to ensure that these were not Ruppia cirrhosa.

The major habitat threat to this species in the reserve are the prolonged regional drought conditions and with their drawdown effects on the water level in the David Lake marshes 
where it was originally reported.

Management considerations for this species would entail resurveying the previously known and potential wetland habitats where it previously had been reported during a moister climatic period when David Lake hast higher water levels. Additionally, any vouching specimens should be reexamined and confirmed, since the record was not included by ANHIC (2002) and Kershaw et al. (2001) in their mapping for the province. At this time, it appears to be likely that the species has been extirpated from the vascular plant flora of the Ecological Reserve. 
Ecological Land Survey Site Description and ANHIC Rare Native Plant Report Information for Ruppia cirrhosa in the Wainwright Dunes Ecological Reserve

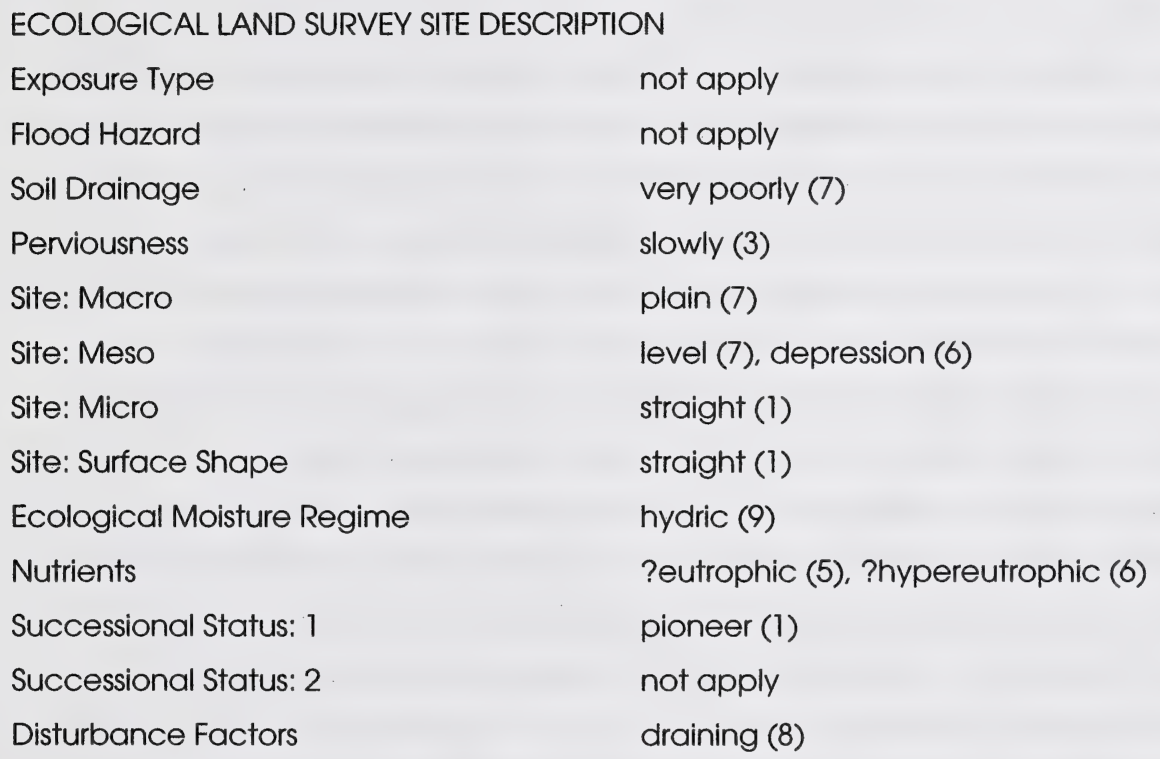

ANHIC RARE NATIVE PLANT REPORT

Phenology: vegetative

no information (June to July?)

Phenology: reproductive - inflorescence no information (June to July?)

Phenology: reproductive - flower

no information (July?)

Phenology: reproductive - fruit

no information (August?)

Habitat Threats

lake water level

Management Considerations resurvey population habitats, confirm collections 


\section{APPENDIX 4}

Elodea bifoliata St John.

\section{-łwo-leaved waterweed-HYDROCHARITACEAE}

This perennial aquatic herb of slough, pond, lake and stream habitats has a provincial Rank of $\mathbf{S 1}$ in Alberta, and a global Rank of G4G5 (Vujnovic \& Gould 2002, ANHIC 2002). This species, which has also been known as Elodea longivaginata St. John, is rooted and completely submergent, with branching stems. It has paired leaves that are opposite, about $2.5 \mathrm{~cm}$ long and $2 \mathrm{~mm}$ wide and are not crowded in the middle to upper portions of the stem. Its flowers, have three tiny white petals, and are on long stalk-like tubes that extend from the leaf axils to the water surface, and produce a small capsule. It may readily be distinguished from Elodea canadensis Michx. (Canada waterweed), which has yet to be confirmed from the province, which has shorter $(1.7 \mathrm{~cm})$ and broader $(2$ to $4 \mathrm{~mm}$ ) leaves that are in whorls of three and are notably crowded along the middle to upper stems. Additionally it differs from the more eastern Elodea nuttallii (Planch.) St. John (Nuttall's waterweed) which also has long, narrow $(0.3$ to $1.5 \mathrm{~mm})$ leaves that are not crowded, but are in obvious whorls of three (Fassett 1957, Muenscher 1972, Voss 1967). At first glance it may be confused with the rare Najas flexilis, but that species has apparent whorls of four leaves (see preceding species summary).

This species occurs in the mid-western North America, is rare in Alberta and Saskatchewan and two northern states, and is considered to have been extirpated from one state (NatureServe 2003, Kershaw et al. 2001). It occurs in Alberta at eight known locations in the Grasslands and western Parkland and adjacent southern Boreal Natural Regions (ANHIC 2003). However, it was not mapped from the eastern portion of the Parkland Natural Region in Rare Vascular Plants of Alberta (Kershaw et al. 2001). Its only report from the Wainwright Dunes Ecological Reserve has been that of Fehr (1984), who listed it as "Elodea canadensis" in the general species list, but gave no location and did not include it in any of his community stand data tables. However, if it does occur within the Reserve, his stated habitat would indicate the pond to the southeast of the Great Fen as being one of several likely locations. The reference floral text for Alberta that Fehr probably used when he conducted his survey would have been the then recently 
published Flora of Alberta of Moss (1959) which listed both Elodea canadensis and Elodea nuttallii, and not the later version of 1983 which listed only Eleocharis longivaginata St. John in the province. Elodea canadensis is an aquatic species that still has not been confirmed from Alberta, and so his record may well have been an understandably mistaken identification of the rare Elodea bifoliata. However, Fehr's record was not repeated in the general accumulative species list that appeared in the Reserve's management plan (Anon 1998) which apparently was edited by several knowledgeable authorities, and who may have excluded the record as being unsubstantiated. The species was not observed during the 2002 survey of the Reserve, and hence its inclusion in its rare flora as based on this record is tentative.

There is no information on the number of individuals of this species within the Ecological Reserve, and the only likely habitat is "pools in willows and some beaver ponds" (Fehr 1984, Appendix 5), which could imply that is was recorded at several locations and in at least two habitats, although the pond southeast of the Great Fen is more probable. There was no information about associated species in the communities, although there may be several associated species of Potamogeton and other aquatics.

The major habitat threats to this species within the Reserve are the prolonged regional drought conditions and their effects on the water level in the beaver pond where it was originally reported. Such habitats were examined during the 2002 survey but no plants were recorded.

Management considerations for this species should include a resurvey during a wetter climatic period of the previously known and potential wetland habitats from which it previously had been reported by Fehr. Additionally, any existing vouching specimens should be found, reexamined and confirmed, since the record was included by neither ANHIC (2002) nor Kershaw et al. (2001) in their rare species mapping for the province. 
Ecological Land Survey Site Description and ANHIC Rare Native Plant Report Information for Elodea bifoliata in the Wainwright Dunes Ecological Reserve

ECOLOGICAL LAND SURVEY SITE DESCRIPTION

Exposure Type

not apply

Flood Hazard

not apply

Soil Drainage

very poorly (7)

Perviousness

slowly (3)

Site: Macro

plain (7)

Site: Meso

level (7), depression (6)

Site: Micro

straight (1)

Site: Surface Shape

straight (1)

Ecological Moisture Regime

hydric (9)

Nutrients ?permesotrphic (4), ?mesotrophic (3)

Successional Status: 1

pioneer (1)

Successional Status: 2

not apply

Disturbance Factors

draining (8)

ANHIC RARE NATIVE PLANT REPORT

Phenology: vegetative

no information (?June to July)

Phenology: reproductive - inflorescence

no information (?June to July)

Phenology: reproductive - flower

no information (?July)

Phenology: reproductive - fruit

no information (?August)

Habitat Threats

pond water level

Management Considerations

refind and monitoring populations 


\section{APPENDIX 5 \\ Muhlenbergia asperifolia (Nees \& Meyer ex Trin.) Parodi \\ -scratch grass-POACEAE}

This distinctive low grass of moist alkaline soil has a provincial Rank of $\mathbf{S} 2$ in Alberta, and a global Rank of G5 (Vujnovic \& Gould 2002, ANHIC 2002). It is a perennial grass that has a thin, scaled rhizome, with procumbent tips from which arise stems with somewhat keeled leaf sheathes, and a notably diffuse panicle, 4 to $12 \mathrm{~cm}$ wide, that is strikingly different from the other Muhlenbergia species in the province which have narrow, spike-like inflorescences. Indeed, its overall growth pattern, particularly when the bushy inflorescence is developed, is strongly reminiscent of Panicum philadelphicum (woodland witch grass) and Panicum flexile (wiry witch grass) of eastern and central North America, or of stunted, low-growing forms of Panicum capillare (witch grass), only the last of which also grows in Alberta. However, these other species are annuals, have very different glume sizes, and lack the well-developed overlapping scaled rhizomes that are typical of all species of Muhlenbergia. The open panicle has a delicate mauve to light purple colour which makes its presence readily obvious in its habitat, and when dry or mature, they break off from the plant and are blown about to spread their seeds. However, in its preflowering vegetative stages, it looks much like a stunted Hordeum jubatum (foxtail barley) and, indeed, probably frequently has been overlooked for this reason; at this stage the presence of rhizomes and lack of hairs on the upper surfaces of the leaf bases would identify the plants as Muhlenbergia asperifolia (Moss 1983, Gleason \& Cronquist 1991, Fernald 1950).

This species occurs across southern Canada between British Columbia to Ontario (where it is an exotic) and across the United States except in the southern and New England states, and is considered to be rare only in Alberta, but extirpated in New York (NatureServe 2003). In Alberta it has 26 known locations in the Grasslands and eastern Parkland Natural Regions, with two from the general vicinity of the study area (ANHIC 2003). It was first reported from within the Wainwright Dunes Ecological Reserve by Wallis (1990) from the vicinity of the northern shore of David Lake. During the present survey thirteen new locations were discovered within the Ecological Reserve, and four from 
beyond its boundaries, in four general clusters near the David Lake peninsula and along the southwestern side of David Lake, with an extensive continuous population along the southeastern to eastern side of the lake.

The number of plants in its locations varied from 50 plants in a $1 \mathrm{~m} \times 2 \mathrm{~m}$ area with small, local dense to diffuse patches, to an outstanding virtually closed meadow of probably over 3000000 plants in a continuous, $150 \mathrm{~m} \times 1000 \mathrm{~m}$ area that extended along the eastern and southeastern offshore of David Lake, but unfortunately, beyond the Ecological Reserve's boundaries. The 2002 survey discovered 72780 plants within the boundaries of the Reserve, all occurring at 13 locations around the David Lake basin.

The general habitat of this species within the province is "moist alkaline soil" (Moss 1983), and the survey of saline wetlands and springs in the Grasslands and Parkland Natural Regions by Wallis (1900) indicated its occurrence in a "drier community of Hordeum jubatum, Puccinellia nuttalliana, Distichlis stricta" (salt grass) north of Medicine Hat (Old Channel Springs Lake), occurring in association with the rare Aster pauciflorus, as is the case here. The behaviour of this species in the Ecological Reserve appears to be reliant of the drawdown condition of David Lake that exposes broad expanses of alkaline sandy soil with a mesic to subhygric moisture regime and, perhaps most importantly, a barren substrate to invade, which it does with a vengeance. The most spectacular habitat in the David Lake basin where the species formed a virtually closed short grass meadow occurs along the lake's entire southeastern and eastern sides. Where it occupied a shoreline to offshore zone that was 150 to $200 \mathrm{~m}$ wide, and extended for over $1000 \mathrm{~m}$ along virtually the entire length of the shore. Here it formed three related zonal communities: nearshore (where it was at the higher limits of the normal lake level and formed a $20 \%$ to $50 \%$ meadow cover that was 20 to $50 \mathrm{~m}$ wide), farshore (where it joined Glaux maritima in forming a $5 \%$ to $20 \%$ cover as a $50 \mathrm{~m}$ wide zone), and offshore (where it formed a $1 \%$ to $5 \%$ cover in an closed offshore meadow that otherwise was strongly dominated by Hordeum jubatum). Off the eastern and southern shores of the David Lake peninsula, this species occurred on alkaline barrens that were more open but of a smaller extent, in effect being local barrens interspersed among the near- and offshore drawdown meadow communities. Here the species presented a variable cover of $2 \%$ to $20 \%$, and 
often was associated with the populations of the rare Aster pauciflorus and Carex parryana. As well, the species occurred in the more densely developed, closed graminoid meadows that occupied the backshore and nearshore habitats, as in the southwestern side of David Lake. These were dominated by Calamagrostis stricta, Juncus balticus, Hordeum jubatum and Agropyron trachycaulum subsp. trachycaulum (slender wheat grass), and the species presented a $1 \%$ to $5 \%$ cover and occurred as an undercover species that often was most readily apparent where grazing had removed the taller grass cover. In at least one instance it displayed it ability to act as an invasive species when it occurred on the disturbed sands of the dugout ditch berm just to the east of the peninsula (site Mal1) with Hordeum jubatum, Agropyron trachycaulum subsp. trachycaulum and several invasive successional species.

As is the case with Aster pauciflorus, the main habitat threats to its present condition may well be the reestablishment of the high water levels in David Lake. Presently the plants have successfully invaded the shoreline to offshore zones of the lake basin, and have formed often extensive closed meadows. A return to high water lavels in the basin would drown the present populations. However, there probably is an outstanding seed bank that is produced by the profusely flowering inflorescences, and these seeds are bound to find refuge along the shore, even if as a much narrower zone. The plant appears to be intolerant of prolonged flooding, so the rhizome may not survive as a propagule with prolonged inundation. Grazing by cattle in the meadows of the David Lake basin appeared to have the effect of opening the cover of taller grasses to expose the shorter plants of this species, and perhaps even to 'release' them to present a denser and more vigorous growth. However, the cattle actually did not appear to selectively eat the species, and any impact appeared to be quite incidental.

Management considerations for Muhlenbergia asperifolia in the Wainwright Dunes Ecological Reserve should include monitoring the populations in the David Lake basin to determine if there is any grazing impact. Additionally, the northwestern, western and southeastern portions of the David lake basin were not surveyed in 2001, and it is very likely that other populations would also be discovered there with further survey. In moister climatic conditions when the drought conditions cease and the lake water level is 
restored, further surveying should be conducted to determine changes in the extent of the populations, and to see if the plants appear elsewhere along the shores. Also, a further survey should examine the shores of the Great Fen pond and the other streams and seeps within the reserve; while no populations were discovered in these habitats in 2002, nevertheless, at least small local populations may be expected. 
Ecological Land Survey Site Description and ANHIC Rare Native Plant Report Information for Muhlenbergia asperifolia in the Wainwright Dunes Ecological Reserve

ECOLOGICAL LAND SURVEY SITE DESCRIPTION

Exposure Type

Flood Hazard

Soil Drainage

Perviousness

Site: Macro

Site: Meso

Site: Micro

Site: Surface Shape

Ecological Moisture Regime

Nutrients

Successional Status: 1

Successional Status: 2

Disturbance Factors

ANHIC RARE NATIVE PLANT REPORT

Phenology: vegetative

Phenology: reproductive - inflorescence

Phenology: reproductive - flower

Phenology: reproductive - fruit

Habitat Threats

Management Considerations not apply

may be expected (3)

poorly drained (6), imperfectly drained (5),

moderately well drained (4)

slowly (3), moderately (2)

plain (7), valley floor (6)

level (7), depression (6)

straight (1)

straight (1)

hygric (7), subhygric (6)

?hypereutrophic (6)

young seral (2)

pioneer (1)

water related (8), grazing (5)

mid- to late July, early to mid-August

mid- to late August

mid- to late August, early September

mid- to late August, early to late September flooding, grazing

monitoring populations, limiting access 
Photo: Muhlenbergia asperifolia

plant detail: plant habit with inflorescence at early to mid-flowering (Ma2-Muhlasp-020815b - O18, photo lan D. Macdonald)

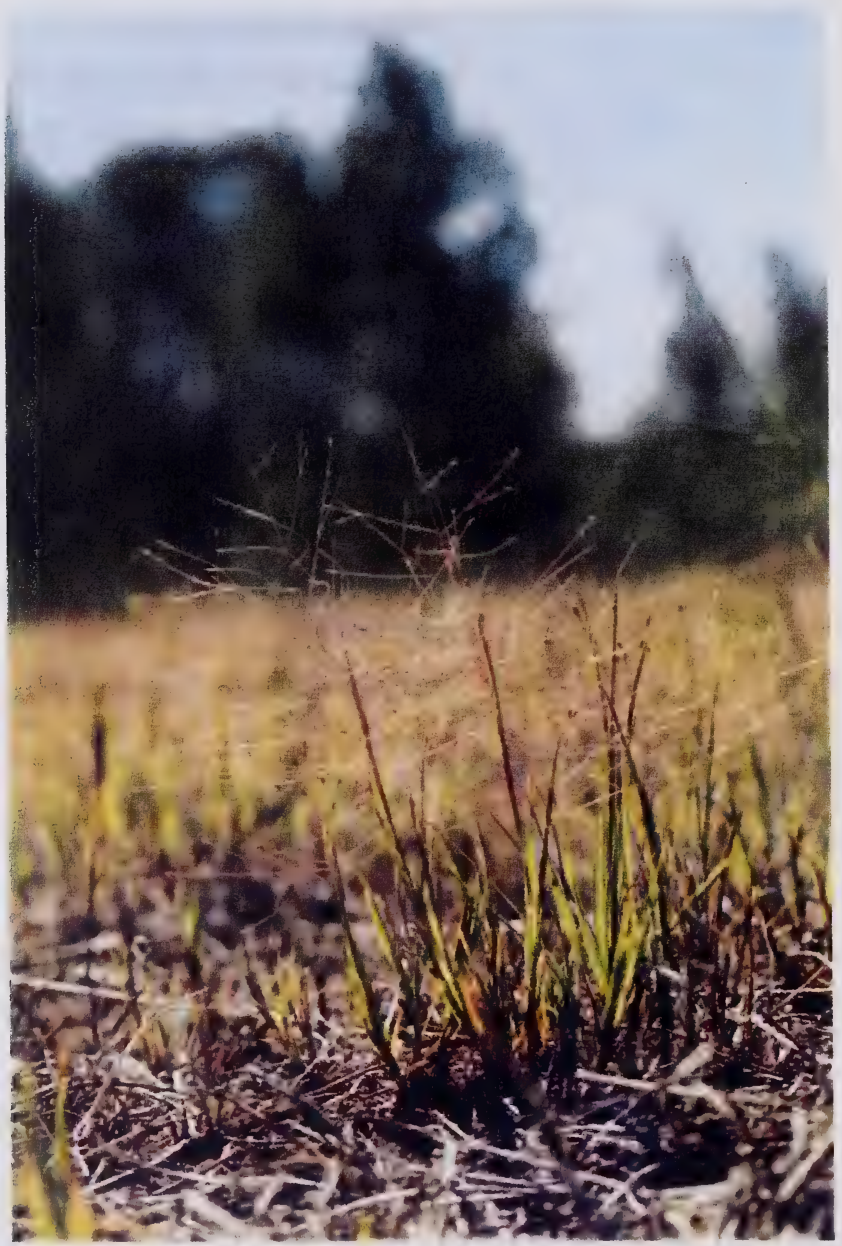




\section{APPENDIX 6}

\section{Carex crawei Dewey}

\section{- Crawe's sedge-CYPERACEAE}

This low to medium height lowland sedge has a provincial Rank of $\mathbf{2}$ in Alberta, and a global Rank of G5 (Vujnovic \& Gould 2002, ANHIC 2002). It is a perennial graminoid, with well-developed rhizomes, and has persisting clusters of the previous year's leaf bases. It has a single terminal staminate spike that is well-separated from the two to three sessile pistillate spikes, and has leaf-like bracts along the stem. The perigynia are glabrous and have three stigmata that develop from green when young to beige with small reddish glandular dots on its surface when mature, with light reddish-brown hyaline scales. A first glance, the species resembles small plants of Carex lanuginosa or others of the Section Hirtae, except that the perigynia are glabrous, not densely if minutely hiruste. Contrary to the comparisons indicated in Rare Vascular Plants of Alberta (Kershaw et al. 2001), the specimens located during this survey did not at all bear any resemblance to Carex aurea, which is a much more delicate plant with orange globose perigynia. Its closest resemblance is to Carex granularis which extends from the east only as far as Saskatchewan, and rather has its staminate spike immediately proximate to the pistillate spikes.

This widespread Northern American species occurs in all the provinces except Nova Scotia and is rare in four other provinces, including Saskatchewan and New Brunswick, and possibly as an extirpated species in British Columbia and Newfoundland - Labrador. As well, it occurs in over two-thirds of the United States and is rare in 13 states, and extirpated from two states (NatureServe 2003, Kershaw et al. 2001). It has a very limited occurrence in Alberta with 13 known locations in the northern and central Rocky Mountain, northeastern Grassland and eastern Parkland Natural Regions (ANHIC 2003), with its nearest location less than $25 \mathrm{~km}$ from the study area, on the low border of Rough Lake, southeast of Wainwright, collected by K.E. Tannas in 1978 (ANHIC 2002، 2003; Moss 1983). Within the Wainwright Dunes Ecological Reserve, it was first reported by Cottonwood Consultants, Ltd. (1986) from the Great Fen basin and from the northwestern end of the large pond near it. In 1992, Derek Johnson and Patsy Cotterill, 
and again in 2001, Patsy Cotterill and Margaret Meijer reported five locations north of the David Lake shore. During the present survey, however, it was found only once, unfortunately outside the Reserve, again in the backshore zone along the north shore of David Lake. Searches in the previously reported locations or in potentially suitable habitats within the study area did not rediscover any additional individuals of this species.

The previous records of Cotterill and Meijer (2001) indicated that "hundreds" of plants of this species were located along the aspen grove on the north side of David Lake. However, searches during the 2002 survey did not rediscover any plants in the backshore grove or tall thicket habitats. However, the current study did discover a small population from the northern backshore of David Lake, but just outside the Ecological Reserve's eastern boundary, with 13 plants occurring in a tight $0.4 \mathrm{~m} \times 0.7 \mathrm{~m}$ cluster, and with most of the plants presenting a developing inflorescence that by early July had at least young fruits that were well on their way to maturing. Since the population was beyond the Reserve's formal study area, only a portion of the potential habitat could be surveyed; there is potential, however, for "hundreds" to occur at that location.

The habitat conditions for the species across the province generally appear to be "calcareous meadows" (Kershaw et al. 2001, Moss 1983). Within the Reserve they were reported to include a patterned fen in the "extensive beaverpond and fen complex" at the Great Fen to the northwest of David Lake, and from an "imperfectly drained edge of an aspen grove" near the lake's northern backshore (ANHIC 2002). The populations that were discovered during the 2002 survey occurred in a subhygric seepage backshore semiopen tall thicket of Salix pseudomonticola, Betula occidentalis, Carex lanuginosa, Juncus balticus and Crepis runcinata (scapose hawk's-beard), in association with other calcareous seepage habitat herb cover species of Carex aurea (golden sedge), Carex viridula, Eleocharis quinqueflora, Primula incana, Senecio pauperculus, Deschampsia cespitosa, and notably with the rare Gentiana fremontii.

Habitat threats to the plants occurring here may be related to the prolonged drought conditions between 2000 and 2002 around the wetlands and lake basin. It is apparent that the subsurface seepage flow along the northern backshore of David Lake has been 
reduced and what now are subhygric moisture regimes probably were in the past at least hygric in moisture climatic conditions. Prolonged drought may induce the invasion and establishment of a more closed shrub cover that may affect the plants. The Great Fen complex currently still has standing water, but evidently not as much as when the species was originally found here, and searches in 2002 did not rediscover the species there. In the case of the population occurring east of the reserve, a conversation with the local rancher, Hilson Maull, indicated that the entire thicket complex along the north shore of David Lake outside the Reserve boundaries was under forest cover to the mid 1990s, but was cut and brushed out to improve grazing capability. This activity must have influenced the present thicket community which is still relatively rich in fen species, including two rare plant species, Carex crawei and Gentiana fremontii. The cattle grazing pattern in the area outside the Reserve boundaries occurred as grazing corridors only a meter or so wide that meander through the community. As well, the cattle use the thicket as a movement corridor at this location, creating several well-worn, east to west trails, with only minor grazing along their immediate margins. Within the Reserve boundaries, no grazing was noted in the Great Fen area, but it was present at a light intensity in the thickets north of the lake.

Management concerns should include monitoring the recently discovered population and attempting to rediscover the previously reported populations, perhaps in moister climatic conditions. It is likely that additional populations occur in suitable seepage and fen-like wetland situations not only along the northern end of the lake, but also along its southern and western sides. An investigation of the reported cutting of the backshore forest for grazing improvement should be undertaken to determine its extent and dates, and whether this activity has damaged or actually improved the habitat for this and the rare gentian species. Since the prolonged drawdown of the water table and lake level probably will advance the invasion of more mesic species into the habitats, any future monitoring should identify the extent of this potential impact. 
Ecological Land Survey Site Description and ANHIC Rare Native Plant Report Information for Carex crawei in the Wainwright Dunes Ecological Reserve

\author{
Exposure Type \\ Flood Hazard \\ Soil Drainage \\ Perviousness \\ Site: Macro \\ Site: Meso \\ Site: Micro \\ Site: Surface Shape \\ Ecological Moisture Regime \\ Nutrients \\ Successional Status: 1 \\ Successional Status: 2 \\ Disturbance Factors
}

ECOLOGICAL LAND SURVEY SITE DESCRIPTION frost (4)

none

imperfectly drained (5), poorly drained (6)

moderately (2)

plain (7), valley floor (6)

level (7)

straight (1), hummocks (2)

straight (1)

subhygric (6), hygric (7)

?permesotrophic (4)

young seral (2)

not apply

site improvement (7), water related (8), grazing (5)

mid-June

Phenology: vegetative

late June, early July

$\begin{array}{ll}\text { Phenology: reproductive - inflorescence late June, } & \\ \text { Phenology: reproductive - flower } & \text { early July }\end{array}$

Phenology: reproductive - fruit

mid- to late July

Habitat Threats

thicket clearing, water table fluctuation,

grazing

Management Considerations monitor population, determine brushing impact 
Photo: Carex crawei (Crawe's sedge)

plant detail: inflorescence with young perigynia

(Cc5-Carecra-02071 1b-E11, photo Ian D. Macdonald)

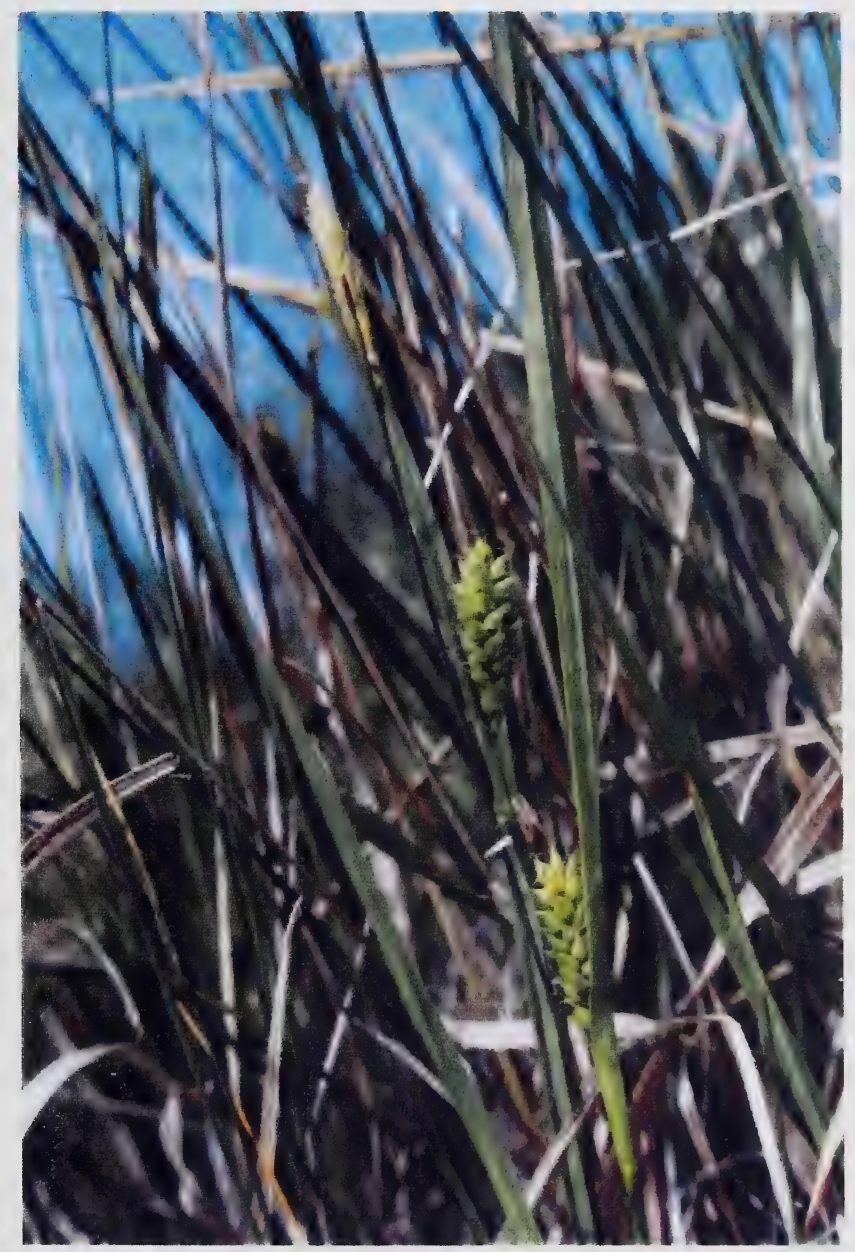


APPENDIX 7

Carex houghtoniana Torr. ex Dewey

\section{-sand sedge-CYPERACEAE}

This upland sedge of dry sandy and gravelly acid sites, gravel pits and open forest habitats has a provincial Rank of S2 in Alberta and a global Rank of G5 (Vujnovic \& Gould 2002, ANHIC 2002). It is a medium-sized perennial erect sedge that spreads by rhizomes, and that has stiff leaves and culm. It has one to several staminate spikes that are well-separated from the two pistillate spikes, with notably hairy perigynia that are 5 to $7 \mathrm{~mm}$ long. This species is similar to the other two members of the Section Hirtae occurring in Alberta, Carex lanuginosa and Carex lasiocarpa, except that its perigynia are longer (rather than from only 2 to $5 \mathrm{~mm}$ long in the above), have distinct, coarse, rib-like veins on its surface (rather than relatively less protrusive veins), have perigynial scales that are notably acute to awned (rather than merely acute), and are shorter than the perigynia (rather than about as long). The foliage tends to be somewhat yellowish green (rather than green to occasionally bluish green), and invariably itis a species of dry, coarsely textured substrate (rather than wetland sites). Additionally, its notably pubescent perigynia separate it from another rare, wetland species, Carex crawei, that also occurs in the Ecological Reserve and has a similar but smaller growth habit.

This species occurs across Canada eastward of the Rocky Mountains, and also is rare in Newfoundland and three states (NatureServe 2003, Kershaw et al. 2001). In Alberta it has 11 known locations with concentrations in the lower elevations of the Rocky Mountain Natural Region west of Edmonton, with isolated locations near Fort McMurray and on the Canadian Shield (ANHIC 2003). It was not mapped from the Parkland Natural Region in the ANHIC (2002) data base, nor in Rare Vascular Plants of Alberta (Kershaw et al. 2001). However, the significant features map in Cottonwood Consultants, Ltd. (1986) indicated that the species occurred within the northwestern portion of the Ecological Reserve northwest of David Lake. C. Wallis (2002) confirmed that this was his record and that he was confident of the record, and further, he thought that he had made a collection that may be at the University of Alberta herbarium. No specimen was found at the provincial parks herbarium. The potential habitats in the general location of his record were 
surveyed during the 2002 project, but in only one instance was the plant thought to be found, although formal determination of the vouching specimen realized that this population actually was Carex lanuginosa occurring in an extremely unusual upland situation.

The typical habitat for this species is a variety of dry upland situations, including gravel pits, sandy \& gravelly acid sites, and open forests. Wallis' record had the species occurring in an active sand dune blowout with light grazing, but no specifics of the habitat or population were available. The active blowout site where the Carex lasiocarpa population was located during the current survey was an otherwise typical, very dry blowout of extremely open sand with Calamovilfa longifolia, Carex pensylvanica var. digyna, Prunus virginiana and the rare Shinneroseris rostrata and Cyperus schweinitzii.

The habitat threats to this species in a blowout situation would be erosion or drifting sand, and the source report (ANHIC 2002) indicated that grazing may have a minor impact. However, the potential locations examined did not present serious impacts from either of these disturbances.

The management considerations for this species would be to confirm the existence of this species within the Ecological Reserve, either through finding and confirming any specimens, or refinding the actual population. In the interim, some measure of access control to the area may be required since signs of ATV trails were in the immediate vicinity. Otherwise the location is remote enough to have had very little human or cattle visitation in the past decade. 
Ecological Land Survey Site Description and ANHIC Rare Native Plant Report Information for Carex houghtoniana in the Wainwright Dunes Ecological Reserve

\author{
ECOLOGICAL LAND SURVEY SITE DESCRIPTION \\ Exposure Type \\ wind (2), insulation (3) \\ Flood Hazard \\ none \\ Soil Drainage \\ well drained (3), rapidly drained (2) \\ Perviousness \\ rapidly (3) \\ Site: Macro \\ plain (7) \\ Site: Meso \\ ?midslope (3) \\ Site: Micro \\ straight (1) \\ Site: Surface Shape \\ concave (2) \\ Ecological Moisture Regime \\ xerix (2), very xerix (1), subxeric (3) \\ Nutrients \\ ?submesotrophic (2) \\ Successional Status: 1 \\ pioneer (1) \\ Successional Status: 2 \\ not apply \\ Disturbance Factors \\ not apply
}

ANHIC RARE NATIVE PLANT REPORT

Phenology: vegetative

no information

Phenology: reproductive - inflorescence

no information (?June to July?)

Phenology: reproductive - flower

no information (?June to July?)

Phenology: reproductive - fruit

no information (?July to August)

Habitat Threats

blowout erosion

Management Considerations

finding \& monitoring populations, limiting access 


\section{APPENDIX 8}

\section{Carex parryana Dewey var. parryana \\ -Parry's sedge-CYPERACEAE}

This perennial semicespitose sedge of moist open meadows, swales and other lowland habitats has a provincial Rank of S1S2 in Alberta, and a global Rank of G4T4 (Vujnovic \& Gould 2002, ANHIC 2002). The plant has stiff basal leaves that rise in loose tufts with reddish-finted bases from a rhizome. There is an erect, obtusely triangular culm that is topped by a tight, narrow inflorescence of stiffly ascending terminal and lateral spikelets, with small perigynia and short staminate spikelets that are crowded at the base of the terminal spike, and a very short, sheathless bract at the base of the bottom spikelet. There is only one sedge species in the ecological reserve that shares its habitats and initially could be confused with this distinctive species, Carex scirpoidea. While this sedge also has stiffly erect culms and basal leaves, it differs in having pubescent perigynia in a single, densely fruited, cylindrical spikelet (Moss 1983).

This species occurs in the northwestern quarter of North America, and also is rare in Ontario, and in Wyoming (NatureServe 2003). In Alberta it has 24 wide-spread known locations in the central Rocky Mountain, Parkland and Grassland Natural Regions, with several known populations in alkaline and salty springs and shore sites occurring within 30 $\mathrm{km}$ of the Ecological Reserve (ANHIC 2003, Kershaw et al. 2001). There were four previous records within the Reserve from the northern shore and vicinity of the peninsula of David Lake, originally recorded by Fehr (1984), Cottonwood Consultants, Ltd (1986) (although not mapped by them), Wallis (1990) and Meijer (2001). The survey in 2002 discovered an additional nine records from within the Reserve around the David Lake basin, with the greatest known concentrations near the David Lake peninsula and the bay on the lake basin's western side. Additionally, several smaller scattered species locations were recorded on the general grassland in the inland body of the peninsula, in the hummocky seepage meadows and in the lake basin's northern backshore. As well, an additional four new records were discovered from the eastern side of the basin, but outside of the Reserve's boundaries, with the probability that similar populations also extend along the southeastern side of the basin's offshore. 
The numbers for this species within the general vicinity of David Lake totaled 23646 individuals, as based on actual counts of culms and basal leaf clusters. Even recognizing that with its rhizomatous character, each individual plant of this species may produce several such clusters, the population still is notable for the province. And, it is likely that many more individuals also occurred elsewhere around the periphery of the lake basin. Within the Ecological Reserve boundaries there were 12621 individuals counted in 13 sampled sites, and outside the boundaries there were 11025 individuals in four sampled sites. The number of plants at the sites varied from about 20 to over 10000 individuals in areas from $4 \mathrm{~m} \times 5 \mathrm{~m}$, to over $100 \mathrm{~m} \times 100 \mathrm{~m}$. As well, along the peninsula's eastern side they occurred as a zone $35 \mathrm{~m}$ wide and $200 \mathrm{~m}$ along the offshore that encompassed 17 widely spaced concentrations with 355 individuals. In 2002, the populations within the reserve were setting leaves and very young inflorescence buds by mid-June, with the inflorescences in full development and in flower by mid- to late June to early July, and with fruit development proceeding from mid- to late June through to mid- or late July.

The inventory of saline wetlands and spring habitats by Wallis (1990) described this species as being a "facultative wetland species, (occurring) in springs" with no other comment in his summarizing species list; however, he also indicated that "(Carex parryana) occurs occasionally on hummocks ... and ... most forbs in this wettest portion of the springs (i.e., wet spring meadows) also occur on hummocks" (page 14), and that it occurred "at Dune Point Springs' saline springs with an open drier area of Distichlis stricta, Puccinellia nuttalliana ... with Aster parviflorus" (page 41). In the Reserve, the largest concentrations of the species around the David Lake basin occurred in the nearshore and offshore drawdown alkaline meadows which are essentially level, and in the hummocky terrain that was created by cattle trampling and grazing patterns. Due to the drought conditions at the time of the 2002 survey, both of these formerly hygric to subhydric habitat situations were mesic to subhygric at best. The community associated with the species was a semiclosed to semiopen graminoid meadow of Distichlis stricta, Calamagrostis stricta, Carex praegracilis (graceful sedge), Deschampsia cespitosa, Agropyron trachycaulum, Juncus balticus, Antennaria parvifolia, Potentilla anserina and others, and it was associated with the rare Aster pauciflorus and Muhlenbergia 
asperifolia. This habitat usually extended some 50 to $100 \mathrm{~m}$ offshore, but not into the increasing concentration of Hordeum jubatum cover that continued as the dominant cover further out into the basin. Backshore and nearshore habitats on the northern and western sides of the lake basin supported rather richer, more closed meadow communities, often with several calcareous seepage associated species that occurred, at least as traces. Typical of these communities were Deschampsia cespitosa, Calamagrostis stricta, Juncus balticus, Agropyron trachycaulum, Glaux maritima, Sonchus uliginosus, Dodecatheon pulchellum, Primula incana, Crepis runcinata and others. Back from the lake basin near the base of the peninsula were several stronglydeveloped hummocky meadow sites which supported local and small populations of the sedge. These had closed, tight carpets of Antennaria parvifolia, Carex stenophylla var. eleocharis (low sedge), Carex scirpoidea, Deschampsia cespitosa, Juncus balticus and others, and may well also have been a habitat for the rare Gentiana fremontii. This habitat apparently occurred on calcareous seepage slopes that normally were hygric, although they were virtually submesic during the 2002 drought conditions. The hummocks themselves appeared to have been created by the trampling of cattle moving through the sites in the wetter conditions, although little grazing was evident during the 2002 survey. These habitats currently supported only very sparse groups of the sedge, but they have potential to have more away from the lakeshore in moister times.

Any habitat threats to the recent plant locations in the lake basin and backshore sites must be related to the prolonged regional drought conditions. The drawdown conditions of the lake level undoubtedly has extended the potential habitat for the species considerably around the David Lake basin. This habitat supported over $85 \%$ of the reserve's population, while during moister climatic conditions the plants probably would be limited to the more narrow shoreline zones around the lake. On the other hand, wetter conditions would revitalize the populations in the seepage slope hummocky meadows which occurred in at least eight depressions in the gently rolling sandland back from the basin's northwestern side. Grazing by cattle did not appear to present a significant impact on the plant locations; the coarseness of the leaves and culms did not appear to be favored over the relatively more palatable grasses in the same habitat. 
Management concerns for the species at this time should include monitoring the populations around the David Lake basin and in the hummocky seepage slope meadows, particularly concerning the long term impacts of the prolonged drought conditions on the foliage and seed production. As noted above, grazing by the resident cattle did not appear to present a problem for the populations here, although such pressures should also be monitored. 
Ecological Land Survey Site Description and ANHIC Rare Native Plant Report Information for Carex parryana in the Wainwright Dunes Ecological Reserve

ECOLOGICAL LAND SURVEY SITE DESCRIPTION

Exposure Type

Flood Hazard

Soil Drainage

Perviousness

Site: Macro

Site: Meso

Site: Micro

Site: Surface Shape

Ecological Moisture Regime

Nutrients

Successional Status: 1

Successional Status: 2

Disturbance Factors

ANHIC RARE NATIVE PLANT REPORT

Phenology: vegetative

Phenology: reproductive - inflorescence

Phenology: reproductive - flower

Phenology: reproductive - fruit

Habitat Threats

Management Considerations not apply

may be expected (3)

moderately well drained (4), imperfectly

drained (5), poorly drained (6)

slowly (3), moderately (2)

plain (7)

level (7), depression (6)

hummocky (2), straight (1)

straight (1)

subhygric (6), hygric (7), subhydric (8)

?hypereutrophic (6), eutrophic (5)

young seral (2)

not apply

water related (8)

early to mid-June

early to mid-June

mid-June to early July

mid- to late June, to mid- to late July

flooding, grazing

monitoring populations and grazing impacts 
Photo: Carex parryana (Parry's sedge)

plant detail: vigorous growth in drawdown lake meadow (Cp 1 1-Carepar-020710c-D15, photo Ian D. Macdonald)

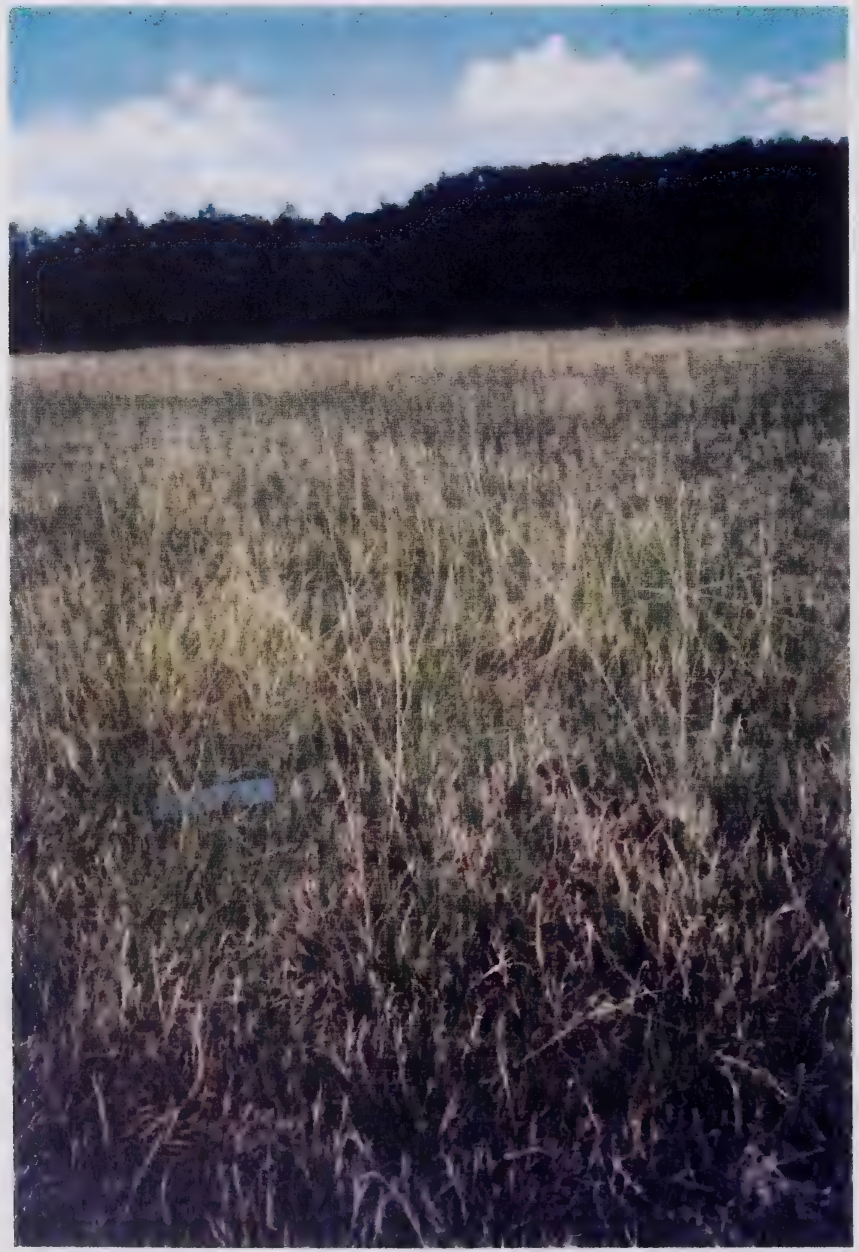




\section{APPENDIX 9 \\ Cyperus schweinitzii Torr. \\ -sand nut-grass-CYPERACEAE}

This distinctive perennial graminoid of dry sand, active sand dune sites has a provincial Rank of S2 in Alberta, and a global Rank of G5 (Vujnovic \& Gould 2002, ANHIC 2002). It has a rhizome that produces corm-like thickenings at its tip, with narrow, scabrous, 2 to 10 $\mathrm{cm}$ long basal and lower culm leaves. The culms are scabrous and triangular and are 10 to $70 \mathrm{~cm}$ tall, with several leafy bracts at its top, and several inflorescences on subsessile to $10 \mathrm{~cm}$ long branches. Each inflorescence tipped with a dense cluster of $1 \mathrm{~cm}$ long spikelets that have alternately-arranged, acuminate, brownish scales and small, hard, brown achenes. There literally is no other medium-height plant in Alberta that resembles this species, except perhaps for certain members of the genus Scirpus, which have a round to oval-shaped spikelet arrangement rather than the regimented planar array of alternate florets that are evident in the genus Cyperus. Its nearest relative is a more eastern species, Cyperus houghtonii that does not enter Alberta, and which has a slightly smaller growth habit, obtusely angled, smooth culms, smooth leaves, and obtuse scales. In its vegetative state it initially may be mistaken for Carex pensylvanica, but that species differs in having very fibrillose rhizomes. In the early summer, the plants of this species may readily be recognized by the accumulation of the previous several years' old culms and inflorescences that form a greying carpet of detritus at the plant bases, creating a somewhat dingy aspect to the lower slopes and bases of the sand dune blowouts. The drought conditions did not appear to greatly affect the growth of this species during the 2002 survey of the Reserve, understandably, since it is a very dry habitat species. This plant often occurred in a general association with the rare Shinneroseris rostrata, and perhaps also with Carex houghtoniana and Chenopodium leptophyllum.

This species occurs in seven provinces from Alberta to Quebec and in 29 states from New England to Texas and the central and mid-western states. It also is rare in Manitoba and Saskatchewan and in eight states including Montana (NatureServe 2003). It occurs in southeastern Alberta with 14 very isolated known locations in the Grassland and Parkland Natural Regions (Kershaw et al. 2001, ANHIC 2003). The location at Wainwright Dunes 
Ecological Reserve appears to have the only known concentration in the eastern Parkland (Kershaw et al. 2001). The species was previously recorded from here by Fehr (1984), Cottonwood Consulting, Ltd. (1986) and Derek Johnston (1992) who together discovered ten locations, with all but one from within the Reserve boundaries. The 2002 survey rediscovered two of these general locations, and added an additional three general clusters with an additional 16 species locations. These were all associated with the eroded dune ridge landforms and were located as clusters to the west, northwest, north northwest and north of David Lake.

The number of plants of this species that were counted in 2002 within the Ecological Reserve's boundaries totaled 9123 plants in the four clusters of 15 sites that were sampled. The number of plants the varied from 35 to over 3000 individual basal leaf clusters with associated culms with inflorescences in areas of from $3 \mathrm{~m} \times 7 \mathrm{~m}$, to $30 \mathrm{~m} \times 85$ $m$. Unfortunately, none of the previous records for the species included population information, except the indications of "very rare". In most cases, the leaf clusters were in fact connected by rhizomes, with at least five per rhizome, and these plants formed a semiopen to semiclosed, low graminoid cover on the blowout sand habitat. In 2002, the plants started to develop leaves in late May to early June, and the leaves were at least half developed by mid-June, and fully developed by mid-July. The culm started to develop by mid-June, and was fully extended by mid-July, and the inflorescence probably was initiated by late June and was mature by mid- to late July. The flowering phase appeared to initiate in early July and continued through mid-July to essentially end by late July. Submature fruits were present by the third week in July and mature fruits were prevalent by mid- to late August. In only one location did the entire group of plants not produce any inflorescences; in all the rest at least $50 \%$ to $70 \%$ of the plants were fertile. As indicated above, the bases of the sandy blowout slopes had notable accumulations of the old inflorescences, and presumably fruits, from the previous years. With the additional moisture and litter, these conditions may provide an opportunity for successful seed germination and seedling survival success.

The sole habitat that this species occupied within the Reserve was the xeric to subxeric, semiactive, semiopen to open sand in the middle to lower slopes of the erosion faces on the southwestern-facing sides of the sand dune ridges. The populations often formed a 
semiopen cover in association with other dune habitat species, notably Calamovilfa Iongifolia, Carex pensylvanica var. digyna, Koeleria macrantha, Carex obtusata, Carex siccata, Festuca saximontana, Stipa curtiseta, Helianthus couplandii, Heterotheca villosa, Artemisia campestris, the moss Tortula ruralis and others, including the provincially rare Shinneroseris rostrata and Chenopodium leptophyllum, and possibly also Carex houghtoniana. The lower slope and the ridge slope draw habitats tended to have a somewhat denser concentration of plants and appeared to initiate their growth earlier in the season; this may have been due to increased soil moisture along the slope base zone. It was not until the mid-summer survey period that plants were noted along the mid- to lower slopes, although by then these often appeared to have formed semiopen to semiclosed covers at the same phenological development stage as at the slope bases. The blowout basins tended to have relatively closed meadows of the Calamovilfa longifolia, Koeleria macrantha, and other associated species, including often very closed carpets of Hudsonia tomentosa and several species of lichen, notably Cladonia mitis, Cetraria ericetorum, Caldonia uncialis, Cornicularia aculeata and others. However, the population of the Cyperus appeared to avoid extending into these more stablized, closed carpets and meadows.

There were no immediate habitat threats to the populations in the reserve. Associated with the sand dune ridge blowout situations were wind-caused erosion and deposition, although only two groups of the species were developed on actively depositing sand and appeared to be maintaining their growth, and no populations appeared to be seriously eroding. Nevertheless, at one location there were signs of recent unauthorized all terrain vehicle ("quad") use in the blowouts, and this may impose an occasional local threat. Additionally, one very local population (Cs26) was not producing any fruits in 2002, although, judging from the previous year's accumulation of productive culms and inflorescences, there was normal production in 2001; this may indicate a failing population, but the situation was by no means typical of anywhere else in the Reserve. Management considerations for maintaining the species in the reserve at this time should include monitoring the size and vigor at the known plant locations. As well, a further survey should include the discovery of additional locations for the plants, since probably only about half of the blowouts in the Ecological Reserve could be examined during the 
2002 survey. Measures should be taken to discourage unauthorized off-road vehicle use in the area, particularly in the vicinity of active sand sites.

\title{
Ecological Land Survey Site Description and ANHIC Rare Native Plant Report Information for Cyperus schweinitzii in the Wainwright Dunes Ecological Reserve
}

\author{
ECOLOGICAL LAND SURVEY SITE DESCRIPTION \\ Exposure Type \\ Flood Hazard \\ Soil Drainage \\ Perviousness \\ Site: Macro \\ Site: Meso \\ Site: Micro \\ Site: Surface Shape \\ Ecological Moisture Regime \\ Nutrients \\ Successional Status: 1 \\ Successional Status: 2 \\ Disturbance Factors \\ wind (2), insulation (3) \\ not apply \\ rapidly drained (2), well-drained (3) \\ rapidly (1) \\ not apply \\ mid-slope (3), lower slope (4), toe (5) \\ straight (1) \\ concave (2) \\ very xeric (1), xeric (2), subxeric (3) \\ ?submesotrophic (2) \\ pioneer (1) \\ not apply \\ not apply
}

ANHIC RARE NATIVE PLANT REPORT

Phenology: vegetative

Phenology: reproductive - inflorescence

Phenology: reproductive - flower

Phenology: reproductive - fruit

Habitat Threats

Management Considerations late June to mid-July

late June to mid July

early to mid- to late July

mid- to late July, and early to mid-August

wind erosion and drifting, recreation

monitoring populations and drought

impacts 
Photo: Cyperus schweinitzii (Sand nut-grass)

plant detail: growth habit

(Cs16-Cypesch-020715c-H2, photo lan D. Macdonald)

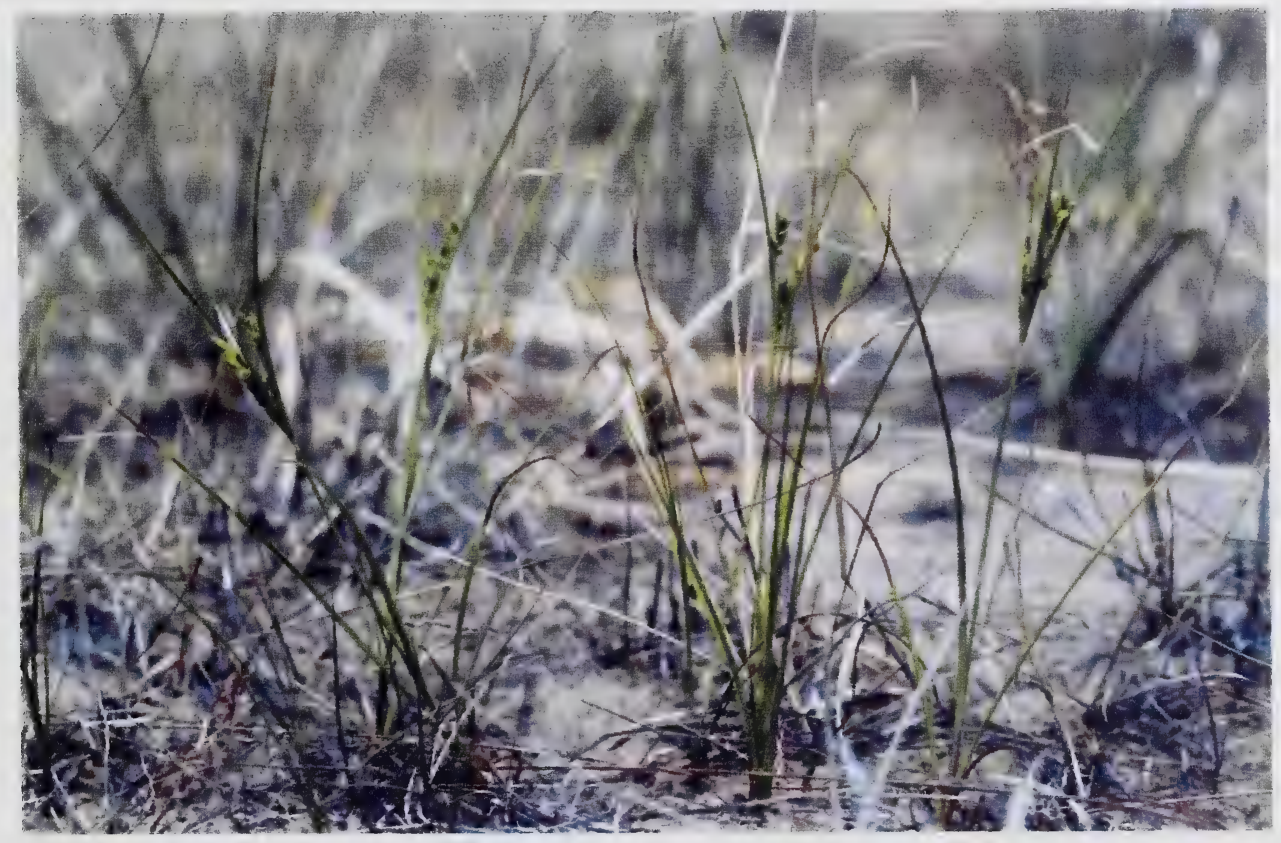




\section{APPENDIX 10}

\section{Eleocharis elliptica Kunth}

\section{-slender spike-rush-CYPERACEAE}

This is a slender graminoid of non-acidic wetlands that has a provincial Rank of SU in Alberta, and a global Rank of G5T5 (Vujnovic \& Gould 2002, ANHIC 2002). It may be distinguished from other spike-rush species by its notably fasciated, or flattened, culm that has a loose reddish purple sheath at its base, and has an achene that is somewhat triangular, distinctly yellowish, with a minute ridge around its crest surrounding its beak. This species recently has undergone some taxonomic revision, with former treatments including Eleocharis tenuis var, borealis and Eleocharis compressa var. borealis (Kershaw et al. 2001). Fehr (1984) reported "Eleocharis compressa var. borealis" from a shrubby fen in his community stand 021 , in the vicinity of Ribstone Creek area to the west of the ecological reserve boundary. During the survey in 2002, the author also collected a plant with fasciated culms and entire brownish culm-bases, also tentatively identified as Eleocharis compressa (Macdonald 020719d6). This species is included in this discussion pending confirmation of the specimens from the study area. At the time of writing, Gould (2003) related that the Reserve's collected plant material is possibly Eleocharis elliptica. However, there is another rare species, Eleocharis mamillata that should be considered. They differ in that the former has proximal bract scales that completely envelop the culm top, while the latter's scles only partially envelop the culms.

This species extends across central and northern North America, occurring in 9 provinces and 24 states, and is rare in Alberta and Saskatchewan, and in one state (NatureServe 2003). It has been mapped in Rare Vascular Plants of Alberta (Kershaw et al. 2001) from one location in the southern portion of the Boreal Forest Natural Region to the west of Edmonton but from only one location in the northwestern portion of the Parkland Natural Region, with none from its eastern portion (ANHIC 2003, Kershaw et al. 2001). Fehr's 1984 report recorded it from the vicinity of Ribstone Creek, west of the Wainwright Dunes Ecological Reserve's boundaries, but Macdonald collected it from a beaver dam southeast of the Great Fen. 
The number of individual plants for this species occurring in the Reserve could not be accurately determined. Fehr gave no number of plants, except that it evidently was "rare", presenting a $0.5 \%$ cover in his sample plots. Macdonald's incidental collection from within the Reserve was of two plants from a concentration of at least 6 plants that presented less than a $1 \%$ cover in its habitat.

The habitat within the Ecological Reserve was a shrubby mixed marsh meadow fringe along a subhygric beaver dam with an extremely open low shrub cover of Cornus stolonifera, and a semiclosed mixed marsh cove of Scirpus microcarpus var. rubrotinctus, Carex urticularia, Lycopus americanus, Lycopus asper, Glyceria striata and others. The habitat to the west of the Reserve was recorded by Fehr (1984) as being a subhydric shrubby graminoid fen along the creek in a flat stream valley basin with a semiopen thicket of Betula pumila, Salix canescens and Cornus stolonifera, and a semiclosed herb cover of Carex aquatilis, Carex utriculata, Eriophorum polystachion, Galium boreale, Carex livida, Menyanthes trifolia and others.

Any habitat threats to the potential number of plants within the Reserve and its vicinity would be related to the drawdown effects of the prolonged drought situation on the beaver ponds and dams, which might change the habitat conditions enough to be unfavourable for the species to survive or to allow other plants to out-compete it. Since the dam crest site also was shared with wildlife and possibly cattle as a trail for crossing the waterway, their trampling or incidental grazing may have an impact.

Management concerns for this species first should be to find and confirm the determination of the collections of Macdonald and, if any exist, of Fehr. The populations also should be refound and monitored to determine the impact of the drought and incidental wildlife and cattle movement and browsing. 
Ecological Land Survey Site Description and ANHIC Rare Native Plant Report Information for Eleocharis elliptica in the Wainwright Dunes Ecological Reserve

ECOLOGICAL LAND SURVEY SITE DESCRIPTION

Exposure Type

frost (4)

Flood Hazard

not apply

Soil Drainage

imperfectly drained (5), poodly drained (6)

Perviousness

moderately (2)

Site: Macro

not apply

Site: Meso

depression (6), level (7)

Site: Micro

irregular (5), straight (1)

Site: Surface Shape

straight (1), concave (2)

Ecological Moisture Regime

hygric (7), subhygric (5), subhydric (8)

Nutrients

?mesotrophic (3)

Successional Status: 1

young seral (2)

Successional Status: 2

not apply

Disturbance Factors

water (8)

ANHIC RARE NATIVE PLANT REPORT

Phenology: vegetative

mid- to late June to early July

Phenology: reproductive - inflorescence

no information (?May)

Phenology: reproductive - flower

no information (?June)

Phenology: reproductive - fruit

no information (?August)

Habitat Threats

drought drawdown of stream

Management Considerations

monitoring populations 


\section{APPENDIX 11}

Chenopodium leptophyllum (Nutt. ex Moq.) Nutt. ex S. Wats.

\section{- narrow-leaved goosefoot-CHENOPODIACEAE}

This annual herb of sandy, open and wooded habitats has an provincial Rank of SU in Alberta, and a global Rank of G5 (Vujnovic \& Gould 2002, ANHIC 2002). It is an erect plant with narrow, lanceolate to linear (rather than broad) leaves that are seasonally farinose (mealy) and tend to be a bluish or light green colour. It has an open panicle of minute green flowers developed in the upper leaf axils and at the terminal growing points of the stem. The determination of this species in the field is considerably problematic since it may be confused with several other common and rare species of Chenopodium. Of particular difficulty is the recognition of the defining minute characteristics without a microscope, such as the flower and fruit pericarp. The combination of leaves with a strictly single vein and absolutely no shorter side veins at the underside bases of the larger leaves, a tight pericarp (thin skin) that closely sticks to the horizontally oriented seeds that, at least at maturity, cannot easily be scraped off the seed, and seeds with a black but slightly wrinkled coating (testa), should separate it from the following four species. The common Chenophyllum pratericola (goosefoot) also is erect, but has leaves with three veins, that often must be very carefully looked for, particularly at their base, and are mealy at least to mid-season, and has a loose pericarp that can readily be separated from the seed. The rare Chenophyllum atrovirens (darkgreen goosefoot, S1 G5) has smaller calyx-lobes that do not cover the mature seed, the plant is somewhat ascending rather than erect, and the larger leaves often have basal lobes. The rare Chenophyllum dessicatum (dried goosefoot, S1S2 G5) also shares small calyx-lobes, but has a loosely attached pericarp, a seed with a dark, shiny, smooth coating, three-veined leaves, and branches notably from the base. The rare Chenophyllum subglabrum (smooth narrow-leaved goosefoot, S1 G3G4) also has a single vein in the leaves, but is quite glabrous except perhaps in the inflorescence, and has a larger seed, about $1.5 \mathrm{~cm}$ long, with a loose pericarp. This is the first record of this species from the Ecological Reserve. However, there is some dispute about the determination of the vouching specimens which may appear to have loosely adherent pericarps, and indeed, may well be another provincially rare species, Chenopodium 
dessicatum (K. Vujnovic 2002, Moss 1983, Gleason \& Cronquist 1991).

This species occurs in the western and central portions of the continent, in six provinces and 37 states. While its provincial Rank is being confirmed in Alberta, it is known to be rare in Ontario and extirpated from Nova Scotia, and is rare in four states (NatureServe 2003, Kershaw et al. 2001). In Alberta, it appears to have scattered locations in the Grassland and Parkland Natural Regions, with at least one station reported from just beyond the northeastern edge and to the south of CFB Wainwright; however, there is no accurate information confirming the number of known locations in the province (ANHIC 2003). This is the first report of the species from the Wainwright Dunes Ecological Reserve, with a cluster of seven locations in its southwestern portion, west of David Lake; the species was not reported in any of the previous biophysical surveys (Fehr 1984, Cottonwood Consultants, Ltd. 1986, Anon 1998). This concentration may be an under representation related to the late seasonal development of the plants and their discovery only late into the 2002 survey period. Hence, the species may well have been overlooked prior to development of the inflorescence, or mistaken for the widespread Chenopodium pratericola. Fehr's 1984 report on the area did not include the species, nor any of the subsequent lists.

A total of 164 individual plants were counted in the seven locations in 2002, all occurring within the Reserve boundaries, possibly with several others to the southwest, which, however, were not properly investigated. The population numbers varied from a single to over one hundred plants in sampled areas of less than $0.1 \mathrm{~m} \times 0.1 \mathrm{~m}$, to $3 \mathrm{~m} \times 45 \mathrm{~m}$.

The main habitat of this species was the sand dune blowout erosion slopes that it shared with the other rare species, Shinneroseris rostrata and Cyperus schweinitzii. This habitat generally was the middle to upper blowout slopes that face southwest to southeast on xeric, semiactive to active, bare sand in association with an open community of Stipa curtiseta, Calamovilfa longifolia, Carex pensylvancia var. digyna, Carex siccata, Helianthus couplandii, Lygodesmia juncea, Carex obtusata, Heterotheca villosa and others, including the common Chenopodium pratericola. In one instance it was situated on the relatively level ground of a subxeric sand plain in an open shrubby grassland of 
Amelanchier alnifolia, Prunus virginiana, Stipa curtiseta, Agropyron trachycaulum,

Festuca campestris, Koeleria macrantha, Selaginella densa and others. It possibly has other upland habitats in the Reserve, but they may have been overlooked in the earlier seasonal phases of the 2002 survey.

The habitat threats to this species would include erosion and deposition of sand from the blowouts, and the long-term effects of the prolonged drought in the region. Grazing from cattle was virtually non-existent in the southwestern portion of the reserve, but may be more of a factor elsewhere.

For this species, the first management concerns would be the confirmation of the vouching collections from the 2002 project. K. Vujnovic (2003) of ANHIC indicated that the specimens would be submitted for an authoritative review, possibly by Prof. H.D. Wilson of Texas A\&M University, the contributor for the genus to Kartesz' (1994) synonymy texts. If this is determined to be a rare species, either Chenopodium leptophyllum or Chenopodium dessicatum, then further surveys should monitor the reported populations and search for further populations in the sandland and dune ridge habitats elsewhere in the reserve. 
Ecological Land Survey Site Description and ANHIC Rare Native Plant Report Information for Chenopodium leptophyllum in the Wainwright Dunes Ecological Reserve

ECOLOGICAL LAND SURVEY SITE DESCRIPTION

Exposure Type

Flood Hazard

Soil Drainage

Perviousness

Site: Macro

Site: Meso

Site: Micro

Site: Surface Shape

Ecological Moisture Regime

Nutrients

Successional Status: 1

Successional Status: 2

Disturbance Factors

ANHIC RARE NATIVE PLANT REPORT

Phenology: vegetative

Phenology: reproductive - inflorescence

Phenology: reproductive - flower

Phenology: reproductive - fruit

Habitat Threats

Management Considerations wind (2), insulation (3)

not apply

well-drained (3), rapidly drained (2),

moderately well drained (4)

rapidly (1), moderately (2)

not apply

mid-slope (3), lower slope (4), level (7)

straight (1)

concave (2), straight (1)

subxeric (3), submesic (4)

?submesotrophic (2)

young seral (2)

not apply

fire (4)

mid- to late July

early August

early to mid-August

mid-August to early September

wind erosion, grazing

monitoring populations and drought

impacts 
Photo: Chenopodium leptophyllum (narrow-leaved goosefoot) plant detail: growth habit and inflorescence (Cl1 - Chenlep-020816b - O6, photo lan D. Macdonald)

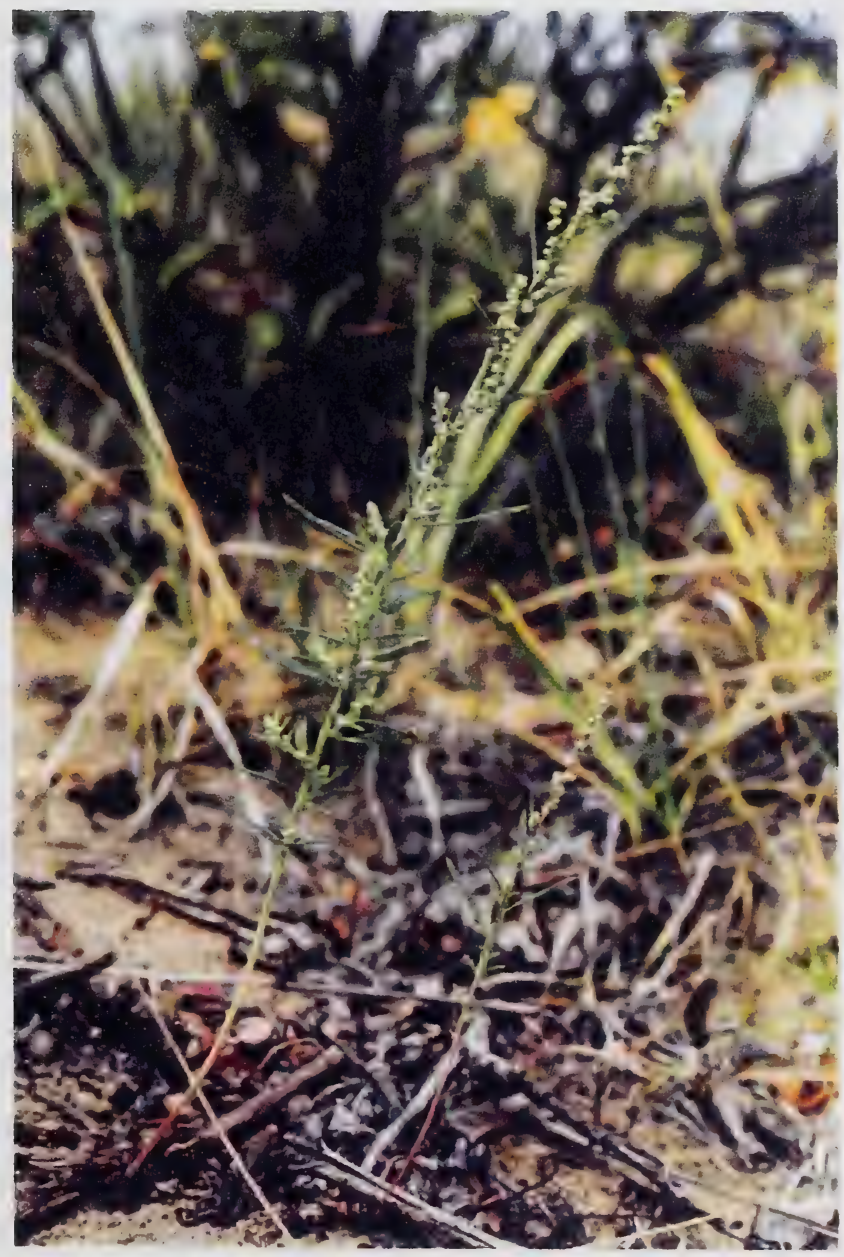




\section{APPENDIX 12 \\ Drosera linearis Goldie \\ -slender-leaved sundew-DROSERACEAE}

This very small perennial herb species of marly bogs, alkaline wet sites and shores has a provincial Rank of $\mathbf{S 2}$ in Alberta, and a global Rank of $\mathbf{G} \mathbf{4}$ (Vujnovic \& Gould 2002, ANHIC 2002). While small, it is very distinctive and easy to identify with its narrow, linear leaves that have reddish, dewy, glandular hairs along the upper leaf surface. Its small white flowers along a raceme, and capsules that hold black oblong seeds. In Alberta it may be mistaken for the related Drosera anglica which more often has obovate - linear, rather than linear, leaves, and has seeds which have distinctly attenuate rather than blunt ends.

This species occurs across Canada and the northern states east of the Rocky Mountains, occurring in eight provinces and five of the northern teir of states. It is considered also to be rare in Saskatchewan, Manitoba and Quebec, and in four of the states (NatureServe 2003). Within Alberta it is reported from 19 known locations in the the Rocky Mountain, Parkland and Boreal Natural Regions in the central portion of the province (ANHIC 2003, , Kershaw et al. 2001). It was first reported by Fehr (1984), from near Ribstone Creek, just to the west of the present Ecological Reserve boundaries, and within the boundaries by him, and later by Cottonwood Consulting, Ltd. (1986) from several areas in the Great Fen. The Great Fen site was searched diligently several times during the 2002 survey, on 15 and 16 June, 20 and 21 July, and 19 August 2002; however, no plants were rediscovered in the tall thicket fen sites or from the adjacent backshore of the large beaver pond on its southeastern side.

The number of plants of almost 20 years ago from the Great Fen, as reported by Fehr (1984), was given on his specimen label as being "fairly common - here very sparse", while the survey of Cottonwood Consulting, Ltd. (1986) did not indicate any numbers or extent. The 2002 survey did not find the species at all, even though a reasonably intensive survey of the ample potential habitat of the Great Fen area was conducted.

Fehrs's community sample 055 from within the Ecological Reserve was located in the 
Great Fen basin, located 1.5 to $3 \mathrm{~km}$ northwest of David Lake. He characterized it as being a hummocky depression on rolling sandland with subhygric organic soil that supported a shrubby graminoid fen with a very open low shrub cover of Betula pumila, and a semiclosed to semiopen herb layer of mosses, Betula pumila suckers, Salix pedicellaris, Carex diandra, Carex limosa, Menyanthes trifoliata, Equisetum fluviatile, Triglochin maritima, Carex aquatilis, Eriophorum viridi-carinatum, Parnassia palustris and other fen species. His survey of the occurrence at Ribstone Creek, outside of the Ecological Reserve's boundaries, also described the habitat as being a subhygric organic stream basin supporting a shrubby graminoid fen of semiopen Betula pumila, Salix canescens and Cornus stolonifera, and semiclosed herb cover in standing water of Carex aquatilis, Carex utriculata, Eriophorum polystachion and other fen species. The survey in 2002 examined the general UTM27 locations of Fehr's report, those of Cottonwood Consulting, Ltd. (1986), and Cliff Wallis' precise locations for this and his Drosera anglica collection (ANHIC 2002), and their immediate and general vicinities. However, no trace of this species was relocated. Nevertheless, the habitat here still appeared to be entirely suitable for this occurrence of this species, in spite of the effects of the drought in which, at least in the early summer when there was only local surface water evident. Neverhteless, by mid-July there was at least 5 to $12 \mathrm{~cm}$ depth of standing water in much of the area. A list of the 86 plant species from this habitat included two notable additions to the Reserve flora which represent considerable range extensions in the province, Minuartia dawsoniensis and Silene menziesii. Additionally, Wallis' (1990) study of saline wetlands and springs in the Grassland and Parkland Natural Regions listed this species as occurring on higher edges and hummocks of wet saline and subsaline meadows along the lake. While this phrasing appears to have referred to the hummocky seepage habitats of David Lake, it is more likely that he referred to the backshores of the large beaver pond at the southeastern end of the Great Fen where, in 2002, the pond level was considerably drawndown and the backshore habitat appeared to be most unsuitable. Further, the active seepage fen $600 \mathrm{~m}$ north of David Lake also was examined, but no populations were discovered there either.

The main and immediate habitat threat to this species probably is the long term impact of the drought conditions within the region, particularly where the critical habitat 
conditions are related to moisture regime, associated community patterns and browsing use of the site by wildlife. Grazing by cattle appeared to have no effect at this time.

The premier management consideration for this species would be to redetermine the species occurrence within the Great Fen basin. No individuals at all were found during the 2002 survey, but there was ample potential habitat in the tall thicket and shrubby graminoid fen habitats occurring within this basin. There should be a clarification of the report by Wallis (1990) for the species' occurrence along the "lake", so as to include or eliminate the David Lake backshore as a habitat within the reserve. An examination and monitoring of the long-term effects of the drought conditions on the fen habitats could be undertaken. 
Ecological Land Survey Site Description and ANHIC Rare Native Plant Report Information for Drosera linearis in the Wainwright Dunes Ecological Reserve

\section{ECOLOGICAL LAND SURVEY SITE DESCRIPTION}

Exposure Type

frost (4)

Flood Hazard

not apply

Soil Drainage

poorly drained (6), very poorly drained (7)

Perviousness

slowly (3)

Site: Macro

valley floor (6)

Site: Mesolevel (7)

Site: Micro

straight (1)

Site: Surface Shape

straight (1)

Ecological Moisture Regime

subhydric (8), hydric (9)

Nutrients

Successional Status: 1

Successional Status: 2

?submesotrophic (2), ?oligotrophic (1)

young climax (7)

not apply

Disturbance Factors

water related ( 8 )

ANHIC RARE NATIVE PLANT REPORT

Phenology: vegetative

late June; early July

Phenology: reproductive - inflorescence

no information

Phenology: reproductive - flower

early to mid- July

Phenology: reproductive - fruit

no information

Habitat Threats

drainage due to drought

Management Considerations

monitoring populations 


\section{APPENDIX 13}

\section{Gentiana fremontii Torr.}

\section{-marsh gentian-GENTIANACEAE}

This very short biennial herb of wet calcareous meadows has a provincial Rank of S2S3 in Alberta, and a global Rank of G4 (Vujnovic \& Gould 2002, ANHIC 2002). This is one of the smallest gentians in the province, reaching only up to $10 \mathrm{~cm}$ tall, and is semiprostrate to erect, with opposite, small, scale-like, ovate leaves. It has single small greenish-purple to white flowers at the stem tips, and capsules that flare at their tips. This species differs from the related Gentiana prostrata of the Rocky Mountains, in having scarcely recurving, white-margined or scarious leaves (rather than distinctly recurving, green-margined in this species), and a capsule that is sessile (rather than on a distinctly elongated stalk). Young plants may be mistaken for a variety of young herb species, notably members of the Caryophyllaceae which also have small, opposite leaves, but thattend not to arise from a small glabrous basal rosette and have separate petals. Indeed, finding this species in its shrubby or meadow habitats is difficult due to its small size. This species has been known as Gentiana aquatilis auct., non L., and was treated under Gentiana prostrata Haenke ex Jacq. var. americana Engelmann in the Flora of Alberta of Moss (1983).

This species occurs in the western third of North America and also in eastern Asia. In Canada it is rare in the two or the four provinces in which it occurs, Alberta and Saskatchewan, and in the United States it is rare in two of the seven states where it occurs (NatureServe 2003, Kershaw et al. 2001). As well, Argus and Pryer (1990) included this species in their list of nationally rare species. In Alberta it has been recorded from ten known locations in the Parkland Natural Region's western portion, with the Wainwright Dunes Ecological Reserve being the only report from its eastern portion (ANHIC 2003). It was first recorded within the reserve by Fehr (1984) from a 1983 collection on the north shore of David Lake, and next by Cottonwood Consultants, Ltd. (1986) who indicated it on the significant features map, and had a 1986 specimen collection by C. Wallis from the vicinity of the peninsula's eastern offshore. Unfortunately, the label reference information is vague or contradictory for both these locations, stating in words the north shore of David Lake, but giving sectional or UTM27 locations removed from the lake or 
their described habitat (ANHIC 2002). The current survey did discover three general locations for the species, with two sampled locations within the Ecological Reserve's boundaries on the northern and southwestern sides of David Lake's backshore, and two proximate locations east of the Reserve's boundary on the lake's northern backshore.

There is no information on the number of plants in the previously discovered locations for this species, except to indicate that they were "occasional". The current survey discovered a total of at least 329 individual plants in 2002; however, only three plants were at two locations within the Reserve boundaries, and the rest were outside the boundaries. Given the difficulty of seeing this very small species in the thicket and graminoid meadow undergrowth, the populations undoubtedly were under-sampled. In the two locations within the boundaries, only one or two plants were discovered within large sampled polygons that were $15 \mathrm{~m} \times 40 \mathrm{~m}$ and $10 \mathrm{~m} \times 30 \mathrm{~m}$. However, it is likely that the number of individual plants is larger, particularly in light of the species location discovered just barely outside the Reserve, where a $15 \mathrm{~m} \times 25 \mathrm{~m}$ sample in the habitat enclosed 142 counted plants in 29 clusters, and another sample had 184 plants counted in 24 small clusters in a $10 \mathrm{~m} \times 107 \mathrm{~m}$ area. Over the entire $110 \mathrm{~m} \times 500 \mathrm{~m}$ area of the tall thicket zone along this portion on the David Lake north backshore, there probably were well over 1000 plants. The phenology of the plants here had flowering plants in Fehr's collection from late May 1983 and Macdonald's record from mid-July 2002, although these probably represent the extreme begining and end to the flowering period, which normally would be in June. In 2002, fruit were developing prior to early July and probably matured into late July, with well over $20 \%$ of the population at mid-fruiting by mid-July, and all seeds matured and shed by mid-August.

Wallis' 1990 study of saline wetland and spring habitats indicated that this is a "facultative wetland species, scarce in saline seepage meadows, most frequent along drier edge in wire rush (Juncus balticus) communities". The collection of A. Fehr at the Alberta Parks and Protected Areas herbarium was from a "hummocky Betula (occidentalis) - Salix (?maccalliana or ?pseudomonticola)" fen which was either associated with the David Lake backshore or was in a depression on the sandlands to the north of the lake. C. Wallis' collection at the University of Alberta herbarium indicated that the habitat was "hummocks and moist meadows (dominated by Antennaria, 
occurring) along the lake". The 2002 survey sampled the hummocky meadows both in the near- and offshore situations along the eastern portion of the David Lake peninsula and the northern side of David Lake, but no populations of this species were recorded. These backshore meadows were dominated by Deschampsia cespitosa, Juncus balticus, Agropyron trachycaulum, Potentilla anserina, Crepis runcinata, and others, while the offshore meadows were dominated by Juncus balticus, Potentilla anserina, Glaux maritima, Agropyron trachycaulum, Deschampsia cespitosa, Puccinellia nuttalliana and Hordeum jubatum. Additionally the well-developed hummocky terrain of the seepage slopes on the peninsula also was searched, but without success. In wetter climatic conditions these sites were hygric with flowing, calcareous surface water. The meadows now, however, supported a much drier complement of species, including the notable carpets of Antennaria parvifolia indicated by Wallis, with Juncus balticus, Distichlis stricta, Calamagrostis stricta, Carex scirpoidea, Glaux maritima, several of the calcareous fen species, such as Primula incana, Lobelia kalmii (Kalm's lobelia), Carex aurea, Senecio pauperculus, and even the rare Carex parryana. The hummock terrain was probably formed by the trampling of cattle through the soft soils as part of their grazing pattern; in many instances these hummocks are over $25 \mathrm{~cm}$ or $35 \mathrm{~cm}$ tall. The Gentiana fremontii plants probably would occur on the crests or sides of these hummocks; however, the species was not recorded from these habitats in 2002, probably due to their now very dry moisture regime caused by the prolonged drought conditions. The plants that were discovered during the 2002 survey occurred in two general backshore thicket and shrubby graminoid fen habitats. These sites would have had hygric to subhydric moisture regimes in wetter climates, but the severe regional drought reduced the available ground moisture to subhygric conditions, with no sign of flowing ground water. The shrubby graminoid fen community had an very open to semiopen, medium height shrub complement of Salix maccalliana, Salix pseudomonticola, Salix petiolaris, Salix planifolia (flat-leaved willow), Betula occidentalis, Populus balsamifera saplings and Salix candida, and a semiclosed herb cover of Carex lanuginosa, Carex aurea, Calamagrostis stricta, Juncus balticus, Deschampsia cespitosa, Potentilla anserina, Carex aquatilis, Festuca ?trachyphylla (tall red fescue), Solidago canadensis (Canada goldenrod) and several species associated with the alkaline seepage sites, such as Carex capillaris subsp. chlorostachys, Eleocharis quinqueflora, Parnassia palustris, Primula incana, Senecio 
pauperculus, Lobelia kalmii, Crepis runcinata, Juncus longifolius, Dodecatheon pulchellum, Gentiana crinita, Gentianella amarella and others, including the rare Lycopus americanus and Carex crawei. The tall thicket community on the lake's northern backshore habitat presented a semiopen tall shrub cover of Salix maccalliana, Betula occidentalis and Populus balsamifera saplings, a semiopen lower shrub cover that included the above tall shrub species and Salix petiolaris and Salix pseudomonticola, and a semiclosed to closed herb cover of Deschampsia cespitosa, Juncus balticus, Potentilla anserina, Carex aurea, Carex scirpoidea, Carex capillaris and many of the calcareous seepage slope species indicated above, but with a more sparse presence. It is likely that this tall thicket community on the lake's northern backshore originally extended eastward from the reserve's eastern boundary onto the now open shrubby graminoid meadow that had the much larger population of Gentiana fremontii. A conversation with the rancher who has been stewarding the area indicated that this area had been cleared of growth in the past ten years, and that the more open shrubby growth had developed since then (Maull 2002).

The major habitat threat to the species in the Reserve is associated with the long-term regional drought conditions that have caused a considerable drawdown of the lake's water level, resulting in a notable lowering of the water table and change in the moisture regime from subhydric to subhygric. As well, the surface water seepage from the springs that previously was prevalent, had virtually ceased. The effect on the habitats has been enough to encourage the species cover values to change, more mesic species to invade, and the species to be exposed to more extreme temperature changes. The clearing of the potential habitats along the northern shore of David Lake may have had both desirable and undesirable effects on the populations. It is apparent that the known population in the cleared area now has quite an impressive size, perhaps due to the 'releasing' effects of opening the canopy. However, such clearing also may have eliminated other features. Actual grazing in the habitats did not appear to have had direct effects on the populations of this rare plant; its small size certainly does not expose it to aggressive selection for forage.

Management considerations here must involve monitoring the known species locations, 
both within and beyond the immediate Reserve boundaries, resurveying the formerly reported hummocky meadow sites when the drought conditions decline, determining the actual impact of the drought on the species' survival, and evaluating the impact of the clearing procedures on the lake's northern backshore thicket habitat for the species.

\section{Ecological Land Survey Site Description and ANHIC Rare Native Plant Report Information for Gentiana fremontii in the Wainwright Dunes Ecological Reserve}

ECOLOGICAL LAND SURVEY SITE DESCRIPTION

Exposure Type

Flood Hazard

Soil Drainage

Perviousness

Site: Macro

Site: Meso

Site: Micro

Site: Surface Shape

Ecological Moisture Regime

Nutrients

Successional Status: 1

Successional Status: 2

Disturbance Factors

ANHIC RARE NATIVE PLANT REPORT

Phenology: vegetative

Phenology: reproductive - inflorescence

Phenology: reproductive - flower

Phenology: reproductive - fruit

Habitat Threats

Management Considerations not applicable (1)

not apply

imperfectly drained (5), poodly drained

moderately (2)

not apply

level (7)

hummocky (2), straight (1)

straight (1)

hygric (7), subhydric (8)

?permesotrophic (4), mesotrophic (3)

?young edaphic (6)

not apply

water (8), site imrpovement (7)

mid- to late May

mid-May to mid-July

late May, to mid-July

late June, to early, mid- to late July

drought drawdown of lake; habitat clearing;

grazing

monitoring populations; drought impact 
Photo: Gentiana fremontii

plant detail: growth habit at mid-flower

(Gf8 - Gentfre-020711a - E7, photo lan D. Macdonald)

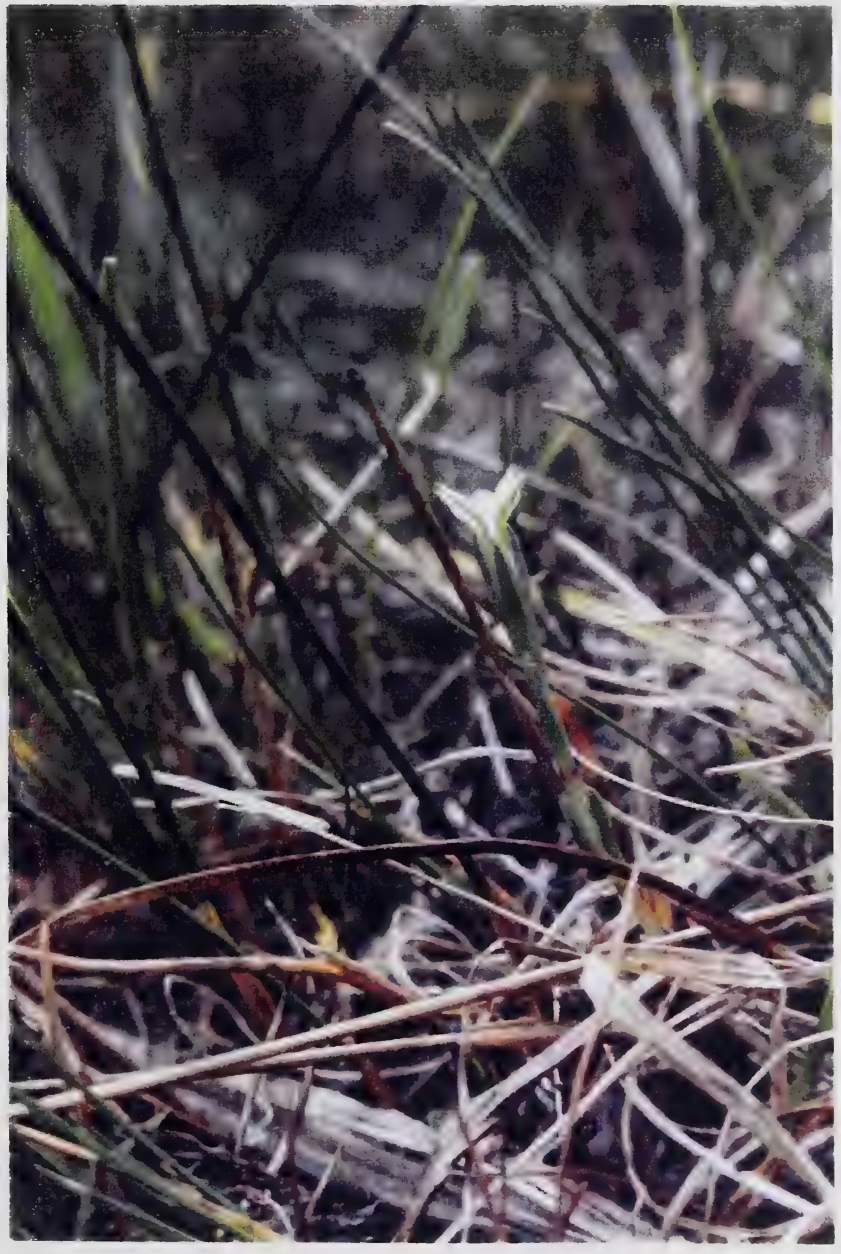




\section{APPENDIX 14}

\section{Asclepias ovalifolia Dcne.}

\section{-low milkweed-ASCLEPIADACEAE}

This medium height herb species of open woods, sloped and moist prairies has a provincial Rank of S3W in Alberta and a global rank G5?, and currently is on the watch list for the province (Vujnovic \& Gould 2002; ANHIC 2002, 2003). It is a perennial broadleaved milkweed which differs from the more common Asclepias speciosa (showy milkweed) in having somewhat pubescent, oval-shaped to lanceolate, opposite leaves that are pointed at the tip, but tapered at their base (rather than cordate or rounded), fruit pods that are smooth (rather than having soft tubercles on the surface), flowers that are greenish-white (rather than pink or purplish), and are somewhat smaller in overall size. Additionally, it differs from the provincially rare Asclepias viridiflora (green milkweed) which is similar in also having greenish flowers and smooth fruits, but often has additional subterminal inflorescences, cordate leaf bases and no 'horn' structure within the flowers (Moss 1983, Scoggan 1979, Gleason \& Cronquist 1991).

This species occurs in the central to west central portions of North America, in five provinces between British Columbia and Ontario, and in ten states along the northern tier of central and midwestern United States. It is rare and possibly extirpated from Ontario, and is rare in five states and is on the provincial Watch list in Alberta (NatureServe 2003, Vujnovic \& Gould 2002). In Alberta, it has 26 known locations which occur within the Parkland Natural Region with several in the southern portion of the Boreal Forest Natural Region (Kershaw et al. 2001, ANHIC 2003). Several localities within $25 \mathrm{~km}$ of the Reserve have been reported (ANHIC 2002). The first reports for this species within the Wainwright Dunes Ecological Reserve were by Bradley \& Bradley (1977) and Fehr (1984), but no species locations were given. Cottonwood Consulting, Ltd. (1986) next reported it from the sandlands to the northwest of the Great Fen pond. This report was reiterated in the management plan for the Ecological Reserve (Anon 1998). During the survey in 2002, an additional sixteen species locations were discovered in four general clusters: two west and one north of David Lake, five northwest and eight north northwest of the Great Fen pond. 
The size of the species locations in the Ecological Reserve varied from $1 \mathrm{~m} \times 6 \mathrm{~m}$ to $25 \mathrm{~m}$ $X 40 \mathrm{~m}$, and their numbers from 4 plants to 444 plants. Throughout the Reserve, the total accumulative number of plants was counted as 1317 plants in 16 the recently sampled locations. In the 2002 survey, their development appeared to have their leaves mostly expanded by mid-June, their inflorescences developed by late June to early July, their flowers mostly at anthesis by early to mid-July and possibly to late July, and fruit development probably normally proceeding between mid- to late July and early to midAugust. However, due to the drought conditions and extreme heat during July 2002, the flowers generally experienced considerable dessication, and essentially had their development toward fruit production arrested by late July. Indeed, none of the species locations investigated during the mid-and late summer of 2002 had any but the most rudimentary fruit development, and in several cases, many flowering inflorescences were abscising from the plant stem by the end of mid-July.

- The habitats of its populations most often occurred along the southwest-facing, uppermost slopes and crests of the low sand ridges that supported submesic to subxeric native grasslands that were adjacent to backslope aspen groves and their marginal zones of successional open thickets of Prunus virginiana and Populus tremuloides saplings. The associated herb cover included Bouteloua gracilis, Calamovilfa longifolia, Selaginella densa, Koeleria macrantha, Agropyron trachycaulum, Stipa curtiseta, Thermopsis rhombifolia (golden bean), Carex pensylvanica and others. In several instances they also occupied openings in young to subintermediate-aged mesic aspen groves and forests in association with Selaginella densa, Bouteloua gracilis, Calamovilfa longifolia, Carex pensylvanica, Oryzopsis pungens, Solidago missouriensis, Thermopsis rhombifolia, Schizachne purpurascens, Aster laevis (smooth aster), Smilacina stellata and others.

There do not appear to be any immediate habitat threats to this species within the Ecological Reserve. Wildlife browsing by deer and moose was very minimal, with only two plants recorded as having been nibbled at one location. Trampling along ungulate trails has a potential impact of the plants but was not actually observed during the 2002 
survey, and cattle grazing was not evident in the portions of the Reserve where the plant populations occurred.

Management considerations for this species would be limited to monitoring the species' populations and cattle grazing patterns in their habitats, and limiting hiking along the convenient ungulate trails. The succession of an aspen grove cover over the habitats in the future may well shade out the species. Burning in the habitats may affect the aboveground plant parts, although the rhizomes probably would persist to further the survival of the plants at their locations. 
Ecological Land Survey Site Description and ANHIC Rare Native Plant Report Information for Asclepias ovalifolia in the Wainwright Dunes Ecological Reserve

\author{
ECOLOGICAL LAND SURVEY SITE DESCRIPTION \\ Exposure Type (88 89) \\ not apply \\ Flood Hazard (90) \\ not apply \\ Soil Drainage (91) \\ rapidly drained (2), well drained (3) \\ Perviousness (92) \\ rapidly (1), moderately (2) \\ Site: Macro (93) \\ plain (7) \\ Site: Meso (94) \\ crest (1), upper slope (2), lower slope (4) \\ Site: Micro (95) \\ straight (1) \\ Site: Surface Shape (96) \\ convex (3), concave (2) \\ Ecological Moisture Regime (97) \\ subxeric (3), mesic (5), submesic (4) \\ Nutrients (98) \\ ?submesotrophic (2) \\ Successional Status: 1 (99) \\ young seral (2) \\ Successional Status: 2 (101) \\ not apply \\ Disturbance Factors (102-106) \\ fire (4)
}

ANHIC RARE NATIVE PLANT REPORT

Phenology: vegetative

mid-June

Phenology: reproductive - inflorescence

mid- to late June, early July

Phenology: reproductive - flower

early to mid- to late July

Phenology: reproductive - fruit

late July, early August

Habitat Threats

trampling, grazing, fire

Management Considerations

monitoring populations, limiting access 
Photo: Asclepias ovalifolia (low milkweed)

plant detail with flowering inflorescence

(Ao7-Asclova-020714b - E22, photo Ian D. Macdonald)

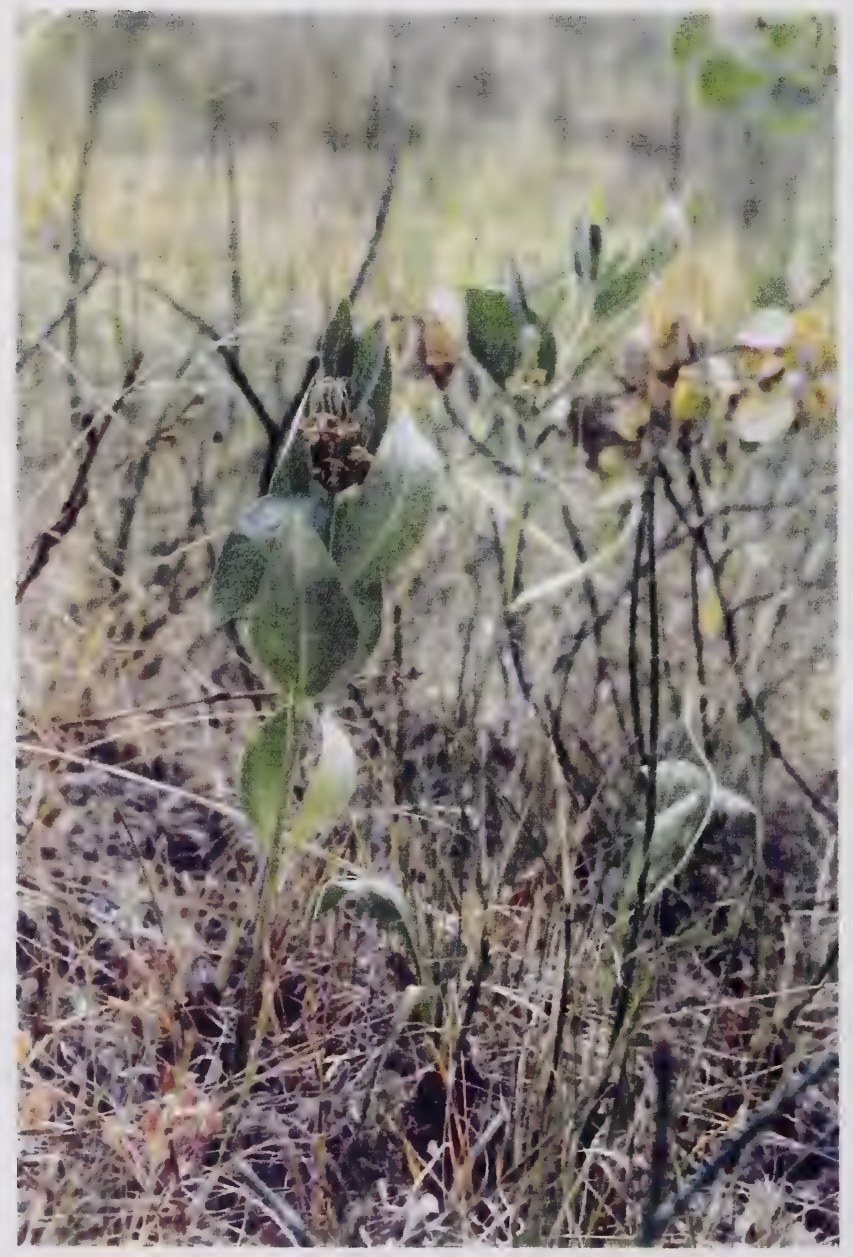




\section{APPENDIX 15}

Lycopus americanus Muhl. ex W.C. Barton

\section{- American water-horehound-LAMIACEAE}

This perennial, low herb species of marshy sites and moist stream sides has a provincial Rank of S2 in Alberta, and a global Rank of G5 Vujnovic \& Gould 2002, Kershaw et al. 2001, ANHIC 2002). It is an erect, deciduous plant with long rhizomes and stolons, growing in the ecological reserve to about $42 \mathrm{~cm}$ tall. It has opposite, deeply toothed, laciniate to pinnate, short hirsute leaves with distinct petioles. The inflorescence has very small, clusters of white, five-petalled flowers in each of the leaf axils, with narrowly triangular sepals that are over twice as long as wide at their base and are up to $2 \mathrm{~mm}$ long. The fruits are nutlets that are $1.0-1.4 \mathrm{~mm}$ wide $X 0.7-1.0 \mathrm{~mm}$ long that form groups of four with a depressed center. This is one of the larger members of this genus in the province. It may be readily differentiated from the common Lycopus asper which has leaves that are merely toothed and are bluntly sessile, and has nutlets that are larger, mostly 1.6 - 2.1 $\mathrm{mm}$ wide $\times 1.4-1.8 \mathrm{~mm}$ long, and bears tubers at the stem base. As well, the common but smaller Lycopus uniflorus that has toothed leaves that taper to short petioles and are essentially glabrous, broadly triangular sepals which are less than twice as long as wide at their base and under $1 \mathrm{~mm}$ in length, and are shorter than the nutlets. Additionally, it may be distinguished from the more eastern Lycopus virginicus which has four petals, and from the European Lycopus europaeus which has longer and stiffer hairs on the lower leaf surface and anthers longer than $0.5 \mathrm{~mm}$, neither of which have been reported in Alberta (Moss 1983, Gleason \& Cronquist 1991, Scoggan 1979).

This species occurs across virtually all of North America south of the 60 latitude, with the exception of Nevada and Labrador, and is considered to be rare in Canada in the provinces of Alberta and Newfoundland, and in the United States in two southeastern states (NatureServe 2003, Kershaw et al. 2001,). Within the province it is known from 14 widely spaced known locations in the Grassland and Parkland Natural Regions, with at least one other station in the Wainwright area (ANHIC 2003). The biophysical studies of the Ecological Reserve and its immediate vicinity by Bradley \& Bradley (1977), Fehr (1984) and Cottonwood Consultants, Ltd. (1986) presented the initial reports of the species 
occurrence here, with at least three locations, and the 2002 survey discovered an additional 17 locations, for a total of 20 . Four of these sampled sites were located around the northern, western and southwestern backshores of the David Lake basin, five to the southeast of the Great Fen pond, three to the northeast of the Great Fen, two in a spring fen north of David Lake, and one outside the eastern boundary of the Reserve north of the lake.

The total population of the species at the various locations within the Reserve is 887 individual plants, with and additional 15 being mere metres outside its eastern boundary. The previous records did not give accurate population sizes, except to indicate that they were "uncommon - here sparse". The populations occurred in areas from $1 \mathrm{~m} \times 3 \mathrm{~m}$ to 10 $\mathrm{m} \times 60 \mathrm{~m}$, and in all probability they also extended around the northern shore of David Lake in a $100 \mathrm{~m} \times 500 \mathrm{~m}$ area. The sampled numbers of individuals in the populations ranged from single plants to over 90 plants, and along the David Lake northern backshore there possibly are over 3000 plants, based on $25 \mathrm{~m} \times 25 \mathrm{~m}$ and $15 \mathrm{~m} \times 30 \mathrm{~m}$ samples within the area. The phenology of the plants in the Reserve in 2002 had the leaves in young development stage by mid- to late June, and at least half developed by early July. The inflorescences were developing in the leaf axils by early to mid-July, and the flowers were appearing over a two month period between early- to late July and into mid- or late August. The nutlet development also was continuous between mid- to late July, to early to mid- to late August, and into early September.

Wallis' study of saline wetlands and springs (1990) described this as being an "obligate wetland species, very local in springs ...". The species occupied three different wetland and lowland habitats within the Reserve. Potentially the largest populations occupy the tall thicket communities of the backshore around David Lake. Along its northern backshore was a subhygric tall thicket of semiclosed Betula occidentalis, Salix maccalliana, Salix planifolia, Salix pseudomonticola, Cornus stolonifera, Juncus balticus, Crepis runcinata, Solidago canadensis, Deschampsia cespitosa, Carex viridula, Carex aurea, Glyceria striata, Senecio pauperculus, Rubus pubescens and others. Also associated with this habitat were several of the calcareous seepage species, such as Parnassia palustris, Lobelia kalmii, Primula incana, and the rare Gentiana fremontii and 
Carex crawei. It is in this extensive habitat that there is the potential for over 3,000 plants to occur. At the southwestern backshore of the lake the species occurred in much sparser numbers in a subhygric semiopen low thicket of Salix lutea (yellow willow), Salix serissima (autumn willow), Salix candida (hoary willow), Calamagrostis stricta, Carex aurea, Juncus balticus, Solidago canadensis and several of the calcareous seepage species, including the rare Gentiana fremontii. Additionally, a modest number of plants of the species was supported in a tall thicket habitat that formed a fringe around a wetland basin $600 \mathrm{~m}$ to the north of David Lake, that also was dominated by Betula occidentalis, Salix pseudomonticola, Salix sericea and Carex aquatilis, with many swamp forest species. Fehr's community sample 043 probably was this same community, but his survey captured it in a non-drought situation, with standing water and a greater variety of marshland sedges, such as Carex aquatilis, Carex lasiocarpa (probably actually Carex lanuginosa) and Carex utriculata being evident. This thicket community also occurred along the lake's northern side, but to the east of the Reserve boundary, no plants of this species were located there. A variation of this thicket community occurring in a subhygric basin in the sand plain which was well-removed from the lake's northern backshore, did support a small population. Fehr (1984) also described a second habitat complex for this species as an open shrubby marsh on the western side of David Lake, also with high water in evidence. His community sample 045 described the species from very scattered Salix (species) and Salix candida in a graminoid marsh of Carex aquatilis, Carex lasiocarpa (?), Carex utriculata, Carex sartwellii (Sartwell's sedge), Calamagrostis inexpansa, Scirpus acutus (great bulrush), Juncus balticus and others. The third major habitat complex in the Reserve was associated with the beaver dams and shorelines of the drawndown beaver ponds, such as those at the southeastern and to the northeast ends of the Great Fen. The dams had a subhygric, sandy and organic substrate and supported an essentially mixed graminoid marsh fringe community of Scirpus microcarpus var. rubrotinctus (small-fruited bulrush), Calamagrostis canadensis, Carex aquatilis, Carex utriculata, Mentha arvensis (wild mint), Lysimachia thyrsiflora (tufted loosestrife), Eleocharis palustris, Lysimachia ciliata, Sonchus uliginosus, Rumex occidentalis (western dock), Glyceria striata, Potentilla norvegica (rough cinquefail) and others. These dams appear to have been used as wildlife trails for crossing the ponds, and some degree of disturbance from the trampling may have created successional conditions 
here. Also associated with the pond drawdown and supporting plants of this species were shoreline marsh meadows of Calamagrostis canadensis, Glyceria grandis, Poa palustris (fowl blue grass), Carex utriculata, Eleocharis palustris, Juncus nodosus, Alopecuris aequalis (short-awned foxtail), Juncus balticus, Catabrosa aquatica (brook grass) and others. The final habitat that the species was discovered in was an active calcareous seepage slope with a shrubby graminoid fen, $600 \mathrm{~m}$ to the north of David Lake, where the plants grew at the base of the shrubs. This hygric site with flowing water had scattered Betula occidentalis over a marsh meadow of Carex utriculata, Carex viridula, Carex aurea, Eleocharis quinqueflora, Solidago canadensis, Gentiana crinita and several of the typical fen species.

Habitat threats in the Reserve for this species were related to the prolonged drought conditions, in particular as they affected the water levels of the pond, stream and lake shoreline habitats. The effect may be variable in the case of the stream and pond banks, where there still may have been sufficient moisture in the soil to allow the species and associated shoreline communities to expand into the wetland basin, as was the case in the stream / pond system to the northeast of the Great Fen. However, on the other hand, the drawdown conditions in other instances have not produced suitable habitat, at least at this time, as is the case in the large pond to the southeast of the Great Fen. Additionally, the use of the beaver dams as game trails may have lead to inadvertent trampling as well as incidental browsing of the plants, as was observed at one site.

Management considerations for this species should include monitoring the known populations and searching elsewhere around the periphery of the David Lake basin and the Great Fen and the other wetland shrubby marsh and thicket communities in the Ecological Reserve. The impact of prolonged drought conditions on the beaver populations also should be examined, since the loss of the beaver dams and associated activities may change the abundance of suitable habitat for this and several other rare vascular plant species, such as the reported Najas flexilis, Elodea biflora and Ruppia cirrhosa. 


\section{Ecological Land Survey Site Description and ANHIC Rare Native Plant Report Information}

for Lycopus americanus in the Wainwright Dunes Ecological Reserve

\section{ECOLOGICAL LAND SURVEY SITE DESCRIPTION}

Exposure Type

Flood Hazard

Soil Drainage

Perviousness

Site: Macro

Site: Meso

Site: Micro

Site: Surface Shape

Ecological Moisture Regime

Nutrients

Successional Status: 1

Successional Status: 2

Disturbance Factors

ANHIC RARE NATIVE PLANT REPORT

Phenology: vegetative

Phenology: reproductive - inflorescence

Phenology: reproductive - flower

Phenology: reproductive - fruit

Habitat Threats

Management Considerations frost (4)

not apply

imperfectly drained (5), poodly drained (6)

moderately (2)

not apply

depression (6), level (7)

irregular (5), straight (1)

straight (1)

hygric (7), subhygric (5), subhydric (8)

?mesotrophic (3)

young seral (2)

not apply

water (8)

mid- to late June to early July

early to mid-July

early to mid- to late July, to mid- to late August

mid- to late July, to early to mid to late August

to early September

drought drawdown of pond / stream / lake:

game trails

monitoring populations; drought impact on

beaver populations 
Photo: Lycopus americanus (American water-horehound) detail of plant growth habit (La17-Lycoame-020719d - J2, photo Ian D. Macdonald)

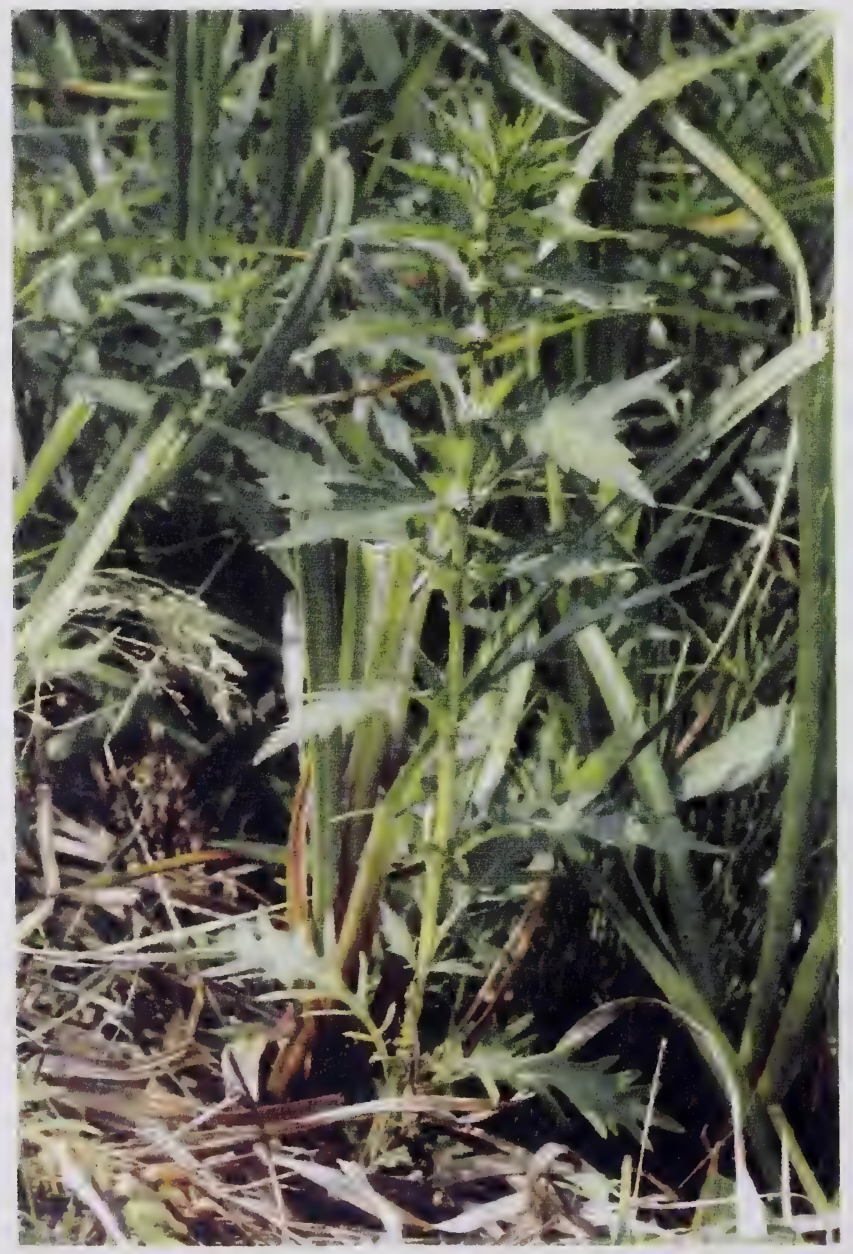




\section{APPENDIX 16 \\ Veronica catenata Pennell. \\ - water speedwell-SCROPHULARIACEAE}

This perennial procumbent low herb of a variety of lowland sites has a provincial Rank of S2S3 in Alberta, and a global Rank of G5 (Vujnovic \& Gould 2002, ANHIC 2002). This is one of the three native species of Veronica occurring in Alberta that have somewhat open racemes which arise from the leaf axils and have strictly glabrous leaves that are more than three times as long as wide. It may be distinguished by its sessile leaves from Veronica americana (which has petioled leaves), and by the clasping bases of the leaves from Veronica scutellata (which has merely sessile leaf bases). Additionally it differs from the non-native Veronica anagallis-aquatica, with which it may be confused, but which previously has not been reported in Alberta, by its shorter leaves that are less than three times as long as wide, and has pedicels that are strongly ascending or upcurved (Scoggan 1979). This species includes Veronica comosa Richt. var. glaberrima (Pennell) Boivin and Veronica salina auct. non. However, it is not recorded under any of the above synonyms in the NatureServe data base of 2003.

It occurs across North America in virtually all the provinces and states, and is rare in Alberta and in 3 states (Kershaw et al. 2001). It has been mapped in Alberta from west of Calgary in the Grassland Natural Region (Kershaw et al. 2001), and has 21 known locations in the province (ANHIC 2003) but apparently with no records reported in the Parkland Natural Region (ANHIC 2002). The record of its occurrence in the vicinity of Wainwright Dunes Ecological Reserve was presented in the biophysical study of the reserve and its general vicinity by L. and C. Bradley (1977) that was reported in the species list in Fehr's (1984) inventory of the general area. However, no information was available for the location or number of individuals, and Fehr himself apparently did not observe the species, so it was not his community sample data. As well, this species was not repeated in the study of Cottonwood Consulting, Ltd. (1986) nor in the accumulative list in the Reserve's management plan (Anon 1998), hence its presence already may have been discounted with the authorative editing for that report. The species was not observed during the 2002 survey, hence there is no recent location information available. 
The habitat of this species in the province appears to be quite diverse, including marshy, muddy or gravelly ground and shallow water by ponds and streams, and in ditches (Kershaw et al. 2001, Moss 1983). The reported habitat of the Bradley's in Fehr (1984) was "wet area near beaver lodge". If the species actually occurs within the Reserve's boundaries, the only beaver lodge recorded still existing was in the large pond at the southeastern side of the Great Fen area, $1.3 \mathrm{~km}$ northwest of David Lake, at about $52 \circ 35.660^{\prime} \mathrm{N} / 110^{\circ} 37.975^{\prime} \mathrm{W}$. This habitat was surveyed for this species in 2002 , but none was found. The drawdown conditions of the pond shoreline habitats may have both altered and eliminated some former and potential habitat sites, but also created newer successional sites for the species.

Any habitat threats for this species would be associated with the drawdown conditions of any wetland shores where it might occur that are caused by the prolonged drought or by cessation of beaver activity. Additionally, there may be impacts from trampling or browsing by wildlife or cattle.

The first management concern for this species would be to find any vouching records for this species within the Reserve boundaries. No collection could be located by the author in the Alberta Parks and Protected Areas or University of Calgary herbaria, and the other herbaria (Alberta Provincial Museum, University of Alberta,) could not be examined for this species. Any potential occurrence of the species recorded by the author during the survey of the study area was determined to be the common Veronica americana. Any discoveries of records or existing populations should be resurveyed and monitored. 
Ecological Land Survey Site Description and ANHIC Rare Native Plant Report Information for Veronica catenata in the Wainwright Dunes Ecological Reserve

ECOLOGICAL LAND SURVEY SITE DESCRIPTION (probably characteristics)

Exposure Type

Flood Hazard

Soil Drainage

Perviousness

Site: Macro

Site: Meso

Site: Micro

Site: Surface Shape

Ecological Moisture Regime

Nutrients

Successional Status: 1

Successional Status: 2

Disturbance Factors

ANHIC RARE NATIVE PLANT REPORT

Phenology: vegetative

Phenology: reproductive - inflorescence

Phenology: reproductive - flower

Phenology: reproductive - fruit

Habitat Threats

Management Considerations frost (4)

may be expected (4)

imperfectly drained (5), poorly drained (6)

moderately (2)

not apply

depression (6), level (7)

irregular (5), straight (1)

straight (1)

hygric (7), subhygric (5), subhydric (8)

?mesotrophic (3)

young seral (2)

not apply

water (8)

no information (?mid- to late June to early July)

no information (?late June to early

September)

no information (?late June to early

September)

no information (?early to mid- to late July, to

early September)

drought drawdown of pond habitat

rediscover and monitoring populations 


\section{APPENDIX 17}

Hedyotis longifolia (Gaertn.) Hook.

\section{- long-leaved bluets-RUBIACEAE}

This low perennial herb of sandy soil in open woods, dunes and grassland habitats has a provincial Rank of $\mathbf{S 2}$ in Alberta, and a global Rank of G4G5 (Vujnovic \& Gould 2002 . ANHIC 2002). It has loosely tufted stems that are $10 \mathrm{~cm}$ to $25 \mathrm{~cm}$ tall, with small, linear, opposite, sessile leaves with purplish stipules. The inflorescence is terminal cymes of white, pink or light blue flowers that have four spreading lobes and a long tube and narrow sepals, and the fruit is a capsule. It also has been called Houstonia longifolia Gaertn. The only other member of this genus in Canada that has similar leaf and inflorescence is Hedyotis canadensis, an eastern species that does not enter the prairie provinces, and the other similar member in the northern United States, Hedyotis nigricans, does not extend further west than the Great Lakes. It bears a passing resemblance to several species of the genera Cerastium and Stellaria, but they differ in having separate petals, rather than petals joined at their base (Moss 1983, Gleason \& Cronquist 1991).

The species occurs in the eastern half of North America from the southern part of western Canada to the Maritimes in five provinces, and southward in 35 states from east central United States to its east coast (NatureServe 2003). It is rare in Alberta, Saskatchewan and Quebec, and in five states, and indeed, is considered to have been extirpated from two states (NatureServe 2003, Kershaw et al. 2001). In Alberta it has 15 known locations from the Parkland and southern Boreal Natural Regions, with several in the vicinity of Wainwright (ANHIC 2003, Kershaw et al. 2001). It was reported from the Wainwright Dunes Ecological Reserve by Cottonwood Consulting, Ltd. (1986) where it was indicated on the sensitive features map as occurring in a sandland aspen grove complex northwest of David Lake. The area was inspected during the 2002 project, but no plants were recorded, perhaps due to the drought conditions, and no population size was indicated in the original source.

The general area where the species was reported from is an aspen successional forest and grove complex. Fehr (1984) did not have a community sample from this area, but 
the associated vegetation was a semiopen, low tree cover of Populus tremuloides, with open tall shrub cover of aspen saplings, Salix bebbiana, Prunus virginiana and Elaeagnus commutata, a semiclosed low shrub cover of Rosa acicularis, Prunus virginiana, Spiraea alba and Juniperus communis (common juniper), and a semiclosed herb cover of Carex siccata, Oryzopsis asperifolia, Oryzopsis pungens, Galium boreale, Smilacina stellata, Thermopsis rhombifolia, Fragaria virginiana, and others.

Habitat threats at this time may be the prolonged drought conditions in the habitat that may have arrested the development of the plants. Fire probably greatly affected this site in the past but recent burning signs were not evident. Grazing was not evident in this portion of the Reserve, and the species is small enough as not to be a favoured grazing species.

Management considerations should include a mid-summer resurvey of this aspen grove for the occcurrence of this species under moister climatic conditions. The impacts of fire and continued cattle grazing management in the area should be evaluated prior to any future burns or increase in grazing pressures. 
Ecological Land Survey Site Description and ANHIC Rare Native Plant Report Information for Hedyotis longifolia in the Wainwright Dunes Ecological Reserve

ECOLOGICAL LAND SURVEY SITE DESCRIPTION

Exposure Type

Flood Hazard

Soil Drainage

Perviousness

Site: Macro

Site: Meso

Site: Micro

Site: Surface Shape

Ecological Moisture Regime

Nutrients

Successional Status: 1

Successional Status: 2

Disturbance Factors not apply

not apply

well drained (3)

moderately (2)

plain (7)

depression (6)

straight (1)

concave (2)

submesic (4)

?submesotrophic (2)

young seral (2)

not apply

fire (4)

ANHIC RARE NATIVE PLANT REPORT

Phenology: vegetative

no information

Phenology: reproductive - inflorescence

Phenology: reproductive - flower

no information (June to July)

Phenology: reproductive - fruit

no information (July?)

Habitat Threats

no information (August?)

Management Considerations

monitoring populations, limiting access 


\section{APPENDIX 18}

Aster pauciflorus Nutt.

\section{- few-flowered aster-ASTERACEAE}

This low, late-flowering herb of alkaline flats has a provincial Rank of $\mathbf{S 2}$ in Alberta and global rank of $\mathbf{G 4}$ (Vujnovic \& Gould 2002, ANHIC 2002). This species also is known as Almutaster pauciflorus (Nutt.) A. \& D. Love (marsh alkali aster) (NatureServe 2003). It may be differentiated from the several asters of similar habitats in the study area, notably Aster ericoides, Aster borealis (marsh aster) and Aster brachyactis (rayless aster), by its narrow, somewhat leathery leaves that are not auriculate and reduce in size upwards along the stem to resemble bracts, its stem which often is procumbent and is increasingly glandular into the inflorescence and flower bracts, its rather loose and unequal threetiered involucral bracts, and its white to bluish ray flowers (Moss 1983, Scoggan 1979. Gleason \& Cronquist 1991).

This species occurs in west central North America, in Canada from the Northwest Territories to Manitoba, and in the southwestern third of the United States through Wyoming and the Dakotas. It is rare in Alberta and in two of the northern states (NatureServe 2003, Kershaw et al. 2001). It has 28 known locations in Alberta, in the vicinity of Red Deer, Medicine Hat and Wainwright (Kershaw et al. 2001, ANHIC 2003), and Wallis (1990) listed it from eleven areas in his survey of saline wetlands and springs in southeastern Alberta. It was first reported by Wallis (1990) from the north side of David Lake, apparently east of the base of the peninsula, and was next located by Miejer (2001), also offshore from the base of the peninsula. An additional eight locations were discovered during the current survey within the Wainwright Dunes Ecological Reserve boundaries to the northeast and east of the David Lake peninsula as a mixture of isolated small clusters, and south of the peninsula as a much larger population. As well, outside the Ecological Reserve boundaries along the eastern offshore of David Lake, there was a notably large population that probably extended well to the southwest along the offshore. Additionally, it is likely that there are other populations around the David Lake basin, particularly on its western side within the ecological reserve boundaries, and on the southeastern and southern sides outside the boundaries. 
Investigation of the calcareous springs to the north of David Lake and around the Great Fen did not reveal additional populations.

A total of 551 individual plants of this species were counted in seven localities within the boundaries of the Ecological Reserve, all along the north side of David Lake and along the eastern side of its peninsula, while outside of the Reserve 6000 were estimated along the lake basin's eastern side, and in all likelihood, the total number of plants from around the lake's entire shore may well approach 10000 . The eight locations on the northeastern and eastern sides of the David Lake peninsula supported single to a dozen plants, and larger population off the southern tip of the peninsula had over 500 plants in a $45 \mathrm{~m} \times 110$ $\mathrm{m}$ area. In the Reserve in 2002, the species developed its inflorescence in early August, and came into flower between mid-to late August and probably to mid-September, with only a few flowers expanding on any one day. Indeed, the petals did not open until the late morning, so that any early morning observations may have overlooked the presence of these star-like flowers. It produced fruit from late August to mid- or late September.

Wallis' 1990 study of saline wetlands and springs in the Grassland and Parkland Natural Regions of Alberta recorded the species generally as being rare to locally common in springs, wet meadow outflows from springs and lake backshores. At Reflex (Old Salt) Lake to the southeast of Chauvin, east of the reserve, he recorded it as occurring "along the lakeshore of a hypersaline lake with sandy and generally saline shore", with associated species there and elsewhere including Muhlenbergia asperifolia, Carex parryana and Gentiana aquatilis (i.e., fremontii), as generally is the case with its species locations here. The most notable habitat for the species was the drawdown offshore barrens of the David Lake basin with its very open, exposed alkaline sand, having over $10 \%$ cover of Glaux maritima, Scirpus pungens, Juncus balticus, Muhlenbergia asperifolia, Potentilla anserina, and Agropyron trachycaulum subsp. trachycaulum and subsp. subsecundum. This habitat supported the larger populations in the David Lake basin, and included vast populations of Muhlenbergia asperifolia. Also supporting smaller and more discrete locations for this species that were were the offshore meadows that extended from the high water level line for about $150 \mathrm{~m}$ into the David Lake basin. These tended to have a semiclosed cover consisting of the above associated species that occurred among the 
hummocky terrain caused by long-term cattle trampling while grazing in the offshore meadows, and probably is the habitat referred to by Meijer (2001). A less common habitat in the study area was the semiopen shrubby meadow along the northern backshore of David Lake where there may have been some groundwater seepage influence. Here the cover was low shrubs of Salix petiolaris and Betula occidentalis and a more closed herb cover of Juncus balticus, Potentilla anserina, Carex scirpoidea, Agropyron trachycaulum subsp. subsecundum and others.

The potential for habitat threats to the populations here must inextricably be linked to the fluctuation of the water level of David Lake, particularly since virtually all the species locations were concentrated in the currently submesic, drawdown zone between about $20 \mathrm{~m}$ and $100 \mathrm{~m}$ offshore from the former high water level line. A return to the high water levels of previous years, however welcome for the other rare species such as Ruppia cirrhosa, would probably greatly reduce the extent of the populations of this species and the rare Muhlenbergia asperifolia and Carex parryana. Grazing did not appear to present an immediate threat to the populations except as an incidental impact from trampling and occasional browsing. The cattle tended to gravitate to the comparatively more lushly developing Hordeum jubatum-dominated graminoid cover of the offshore and did not dwell in the short and sparse meadows and barrens. It was observed, however, that grazing in the denser offshore Juncus balticus swards may at least locally have removed the shading of the graminoid cover and apparently 'released' the plants.

Management considerations should include monitoring the current populations to ascertain how well they are surviving the drought conditions and prolonged drawdown of the alkaline lake bed. It is likely that when the drought ends and the lake level rises, the population will be greatly reduced and probably will be restricted to its currently more marginal habitats; However, undoubtedly, the rhizome, and possibly also the seed banks, will persist to take advantage of another drawdown period. The impact of grazing also could be examined, although as noted above, at this time it did not appear to be significantly detrimental. 
Ecological Land Survey Site Description and ANHIC Rare Native Plant Report Information for Aster pauciflorus in the Wainwright Dunes Ecological Reserve

\author{
ECOLOGICAL LAND SURVEY SITE DESCRIPTION \\ Exposure Type \\ Flood Hazard \\ Soil Drainage \\ Perviousness \\ Site: Macro \\ Site: Meso \\ Site: Micro \\ Site: Surface Shape \\ Ecological Moisture Regime \\ Nutrients \\ Successional Status: 1 \\ Successional Status: 2 \\ Disturbance Factors \\ not apply \\ may be expected (3) \\ poorly drained (6), imperfectly drained (5), \\ moderately well drained (4) \\ slowly (3), moderately (2) \\ plain (7), valley floor (6) \\ level (7), depression (6) \\ straight (1) \\ straight (1) \\ hygric (7), subhygric (6) \\ ?hypereutrophic (6) \\ young seral (2) \\ pioneer (1) \\ water related (8)
}

ANHIC RARE NATIVE PLANT REPORT

Phenology: vegetative

Phenology: reproductive

Phenology: reproductive - flower

Phenology: reproductive - fruit

Habitat Threats

Management Considerations mid- to late July, early to mid-August early to mid- to late August mid- to late August, early September late August, early to late September flooding, grazing monitoring populations, limiting access 
Photo: Aster pauciflorus (few-flowered aster) plant detail: inflorescence and flower (Ap3-Astepau-020815a-O23, photo Ian D. Macdonald)

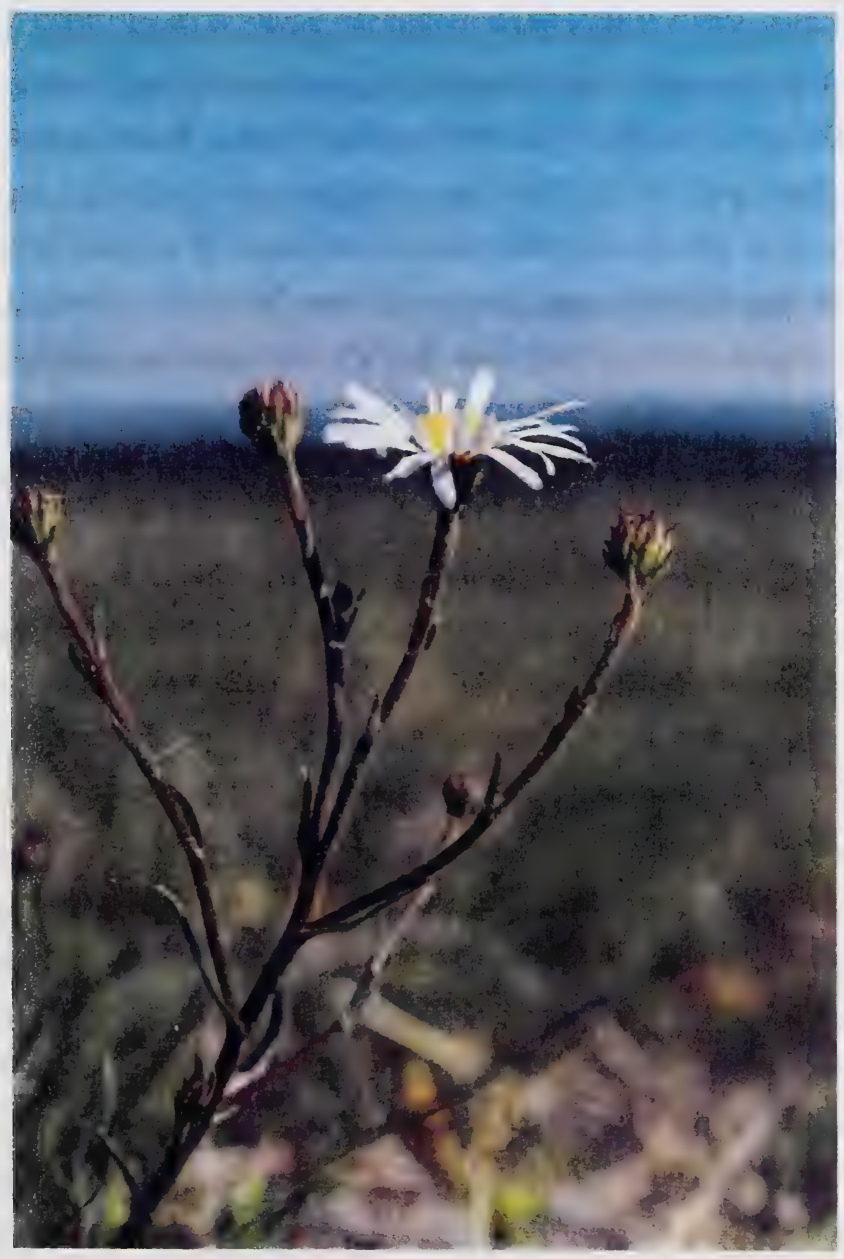




\section{APPENDIX 19}

Shinnersoseris rostrata (A. Gray) S. Tomb

\section{-annual skeletonweed-ASTERACEAE}

This annual, low herb of sandy bank, dunes and loose sand habitats has a provincial Rank of S2 in Alberta, and a global Rank of G5? (Vujnovic \& Gould 2002, ANHIC 2002). Shinneroseris rostrata has erect, slightly branching stems, which in the Reserve grow to a height of about $25 \mathrm{~cm}$. It has slightly arching and soft, linear, three-veined, sessile, glaucous leaves that are $5 \mathrm{~cm}$ to $20 \mathrm{~cm}$ long. Its inflorescence forms a relatively flattopped, open panicle with pink ray flowers in an involucre of a cluster of very small, acuminate-ovate bracts at the base of seven to nine, $10 \mathrm{~mm}$ to $16 \mathrm{~mm}$ long, linear bracts, and it produces achenes that have a white, non-plumose pappus. This species was formerly called Lygodesmia rostrata A. Gray, and its nearest relative is another member of that genus, Lygodesmia juncea (Pursh) D. Don (skeletonweed), which invariably occurred with this species, and may be somewhat similar on first viewing (Moss 1983, Scoggan 1979). However, the Lygodesmia juncea differed in being a much more sprawling plant, growing as a perennial by a rhizome, with stiff, straight to only slightly arching, subulate (awl-shaped) leaves that also are glaucous but rarely attain $5 \mathrm{~cm}$ in length, a more diffuse inflorescence that frequently is not a well-defined panicle, with an involucre of small basal bracts that are more narrowly acute, and with only five linear larger bracts, and a sap that is notably yellow rather than white. Another provincially rare, pink-flowered, paniculate, erect plant with which it may be confused is Stephanomeria runcinata, which is limited to the Grassland Natural Region in the province. It differs in being a perennial, having backward-pointing teeth on the leaves, and having a distinctly plumose pappus atop the achene. As well, drought-stressed, stunted plants of the more common Lactuca pulchella could be mistaken for the species, but differed from these by typically having blue flowers with an even gradation in bract sizes in the involucre. In seeking these plants in their habitat, their presence also frequently was obscured due to their resemblance to the glaucous leaf colour and similar leaf projection angles and lengths of the common sand dune grass, Calamovilfa longifolia; so a careful examination in their potential habitat is warranted. 
The species occurs in central western North America from the southern parts of the prairie provinces southward toward Texas and into Mexico. It is rare in Alberta, Saskatchewan and Manitoba, and three of the northern midwestern states (NatureServe 2003, Kershaw et al. 2001). In Alberta it has 11 known locations along the eastern side in the Grassland and Parkland Natural Regions of the province, with two known stations in the general vicinity of Wainwright (ANHIC 2003). It was initially recorded from the northeastern portion of the Wainwright Dunes Ecological Reserve by Cottonwood Consultants, Ltd. (1986), and was later collected by Derek Johnson in 1992; their records were repeated in the Reserve's management plan (Anon 1998). The 2002 survey of the Reserve refound at least one of the Cottonwood's general locations, and added four general clusters, all within the Reserve's boundaries, to the west, northwest and north northwest of David Lake. The UTM grid location cited by Johnson in 1992 that appeared in the ANHIC Element Occurrence data sheet was relocated and surveyed, but no typical habitat for the species was discovered (see map Sr3).

These five clusters supported 18 sampled species locations that typically varied in size from $1.5 \mathrm{~m} \times 2 \mathrm{~m}$ to $4 \mathrm{~m} \times 35 \mathrm{~m}$, and had numbers of plants ranging between 2 and 20 plants, although in one case a $2 \mathrm{~m} \times 4 \mathrm{~m}$ area held 60 plants, and in another there were 15 plants spread over an $8 \mathrm{~m} \times 75 \mathrm{~m}$ area. The total number of plants of this species discovered within the Ecological Reserve's boundaries was 257 individuals. The plants appeared to have been greatly affected by the prolonged drought conditions, and were producing well-developed inflorescences by mid- to late July, with successful fruit production by mid- to late August, and possibly into early or mid-September. The inflorescences of virtually all the examined plants continuously produced both flowers and fruits between at least a six to eight week period after mid-July, and in all probability each plant had the capability of producing over 50 viable seeds. Since this species is an annual, the current year's plants would disappear at the end of the season, and the limiting factor in establishing the following year's populations through seed germination may well be the presence of rainfall, as well as the deposition of the seeds on suitable sandy habitat. Nevertheless, with the 2002 growing season was markedly devoid of rainfall with only rare cloudburst downpours or very brief, transient light rains. Nevertheless, such moisture conditions apparently were sufficient for the species to have 
become reestablished at many of the potential sites examined during the project.

The prime habitat for this species within the Ecological Reserve was the subxeric to xeric, semiopen sand of the southwest-facing, semiactive to active erosion faces on the upper to middle slopes and draws along the sand dune ridge blowout basins. The associated community here was composed of Calamovilfa longifolia, Stipa curtiseta, Koeleria macrantha, Carex pensylvanica var. digyna, Elymus canadensis (Canada wild rye), Oryzopsis hymenoides, Sporobolus cryptandra, Carex obtusata, Carex siccata, Carex praegracilis, Lygodesmia juncea, Festuca saximontana, Helianthus couplandii, Heterotheca villosa and others, including the provincially rare Cyperus schweinitzii and Chenopodium leptophyllum. In may instances the plants occurred along the uppermost reaches of the erosion face slope, but also extended locally toward, but only barely into, the low thickets that were fringing the dune ridge crests. Here the associated species included Prunus virginiana, Juniperus communis, Rosa acicularis, Calamovilfa longifolia, Rhus radicans var. rydbergii (poison ivy) and others, as well as Lygodesmia juncea, which often formed a diffuse tangle that obscured the presence of the plants. In only one instance did it occur in the lower slope of a semiactive to semistable blowout basin, with an associated community dominated by Cyperus schweinitzii.

The main habitat threat to this species probably is the prolonged drought conditions in the region, although it appears to have been successful in surviving the drought of the past several years. Erosion and deposition from blowing sand may remove the seed bank from suitable germination sites, and in only one instance was a current population immediately in danger of being buried in actively depositing dune sand. Cattle grazing was not evident in any of the sites examined, but one dune ridge in the western portion of the reserve did have some evidence of an all terrain vehicle ("quad") using the sandy slopes for unauthorized travel.

The management considerations for this species should include monitoring the known populations in order to establish what the regeneration success might be from the previous years' seed production. Since this is an annual, but apparently with a good potential for seed production and apparently an ability to germinate readily, such 
monitoring would be valuable in realizing further management actions required to preserve the species. Additionally, there likely are more populations in the semiactive sand dune ridge blowout situations elsewhere within the Reserve, and further surveying probably would be fruitful. The infringement of all terrain vehicle traffic on the sand dune ridge blowouts should be actively discouraged, so as to protect this sensitive and significant habitat. 
Ecological Land Survey Site Description and ANHIC Rare Native Plant Report Information for Shinneroseris rostrata in the Wainwright Dunes Ecological Reserve

\author{
ECOLOGICAL LAND SURVEY SITE DESCRIPTION \\ Exposure Type wind (2), insulation (3) \\ Flood Hazard not apply \\ Soil Drainage $\quad$ rapidly drained (2) \\ Perviousness rapidly (1) \\ Site: Macro not apply \\ Site: Meso \\ upper slope (2), mid-slope (3), lower slope (4) \\ Site: Micro \\ Site: Surface Shape \\ straight (1) \\ concave (2) \\ Ecological Moisture Regime \\ very xeric (1), xeric (2) \\ Nutrients \\ ?submesotrophic (2) \\ Successional Status: 1 \\ Successional Status: 2 \\ pioneer (1) \\ not apply \\ Disturbance Factors \\ not apply
}

ANHIC RARE NATIVE PLANT REPORT

Phenology: vegetative

mid-July

Phenology: reproductive - inflorescence early to mid- to late August, early September

Phenology: reproductive - flower early to mid- to late August, to early September

Phenology: reproductive - fruit mid- to late August, to early to mid-September Habitat Threats wind erosion, grazing

Management Considerations monitoring populations and drought impacts 
Photo: Shinneroseris rostrata (annual skeletonweed)

plant detail: growth habit with flowering inflorescence (Sr17-Shinros-020816b-O8, photo lan D. Macdonald)

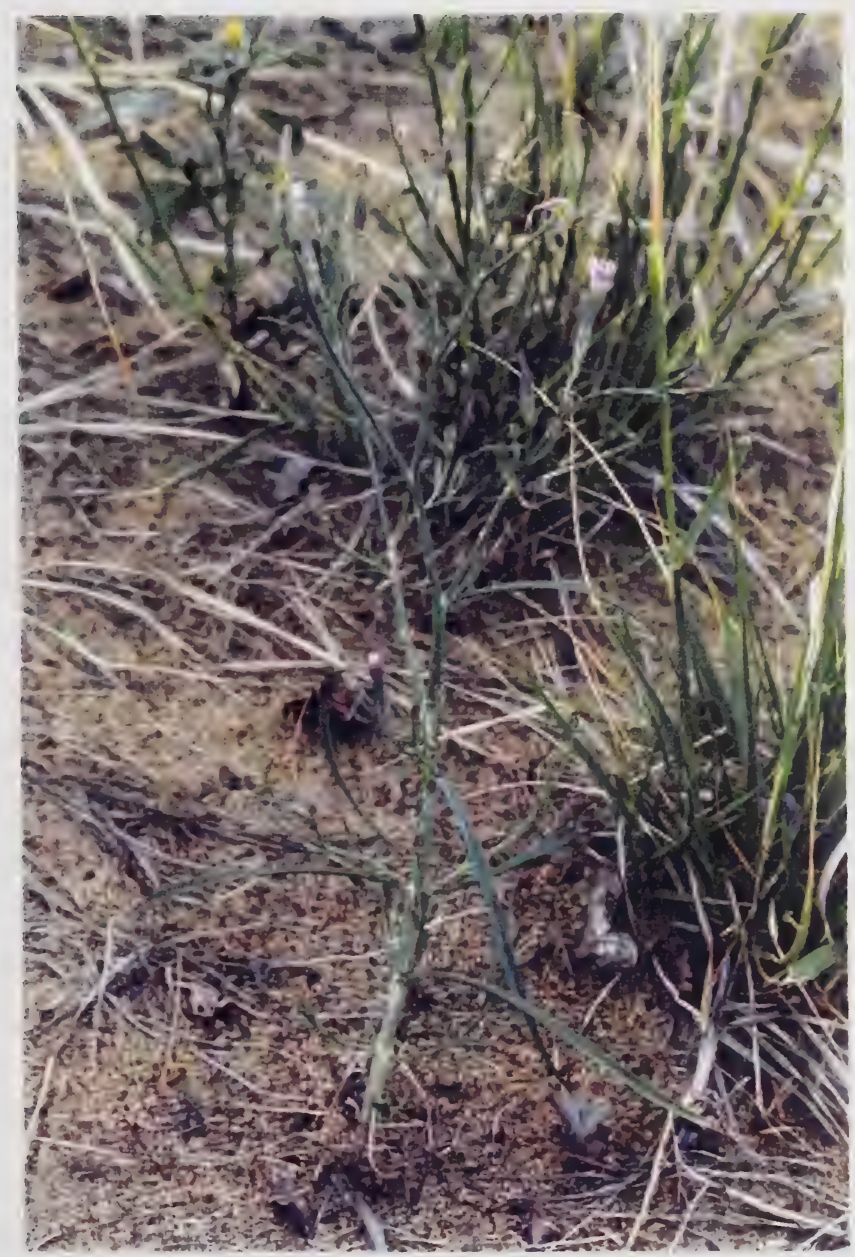




\section{APPENDIX 20: WAINWRIGHT DUNES ECOLOGICAL RESERVE VASCULAR PLANT FLORA}

The following compilation list of vascular plant species that have been confirmed from within the boundaries of the Wainwright Dunes Ecological Reserve. It is based on the several reports and observation and collection notes made between 1977 and 2002, notably Bradley \& Bradley (1977), Fehr (1984), Cottonwood Consultants, Ltd. (1986), Wallis (1990), the reserve's management plan (1998), Miejer (2001), Johnson (1992), Cotterill (2000), Alberta Natural Heritage Information Centre (ANHIC) (2002) and the author (Macdonald 2002). There are 418 confident records and an additional 8 tentative records that have been confirmed as occurring within the current ecological reserve's boundaries. The largest families listed here are Asteraceae (62 species), Poaceae (55) and Cyperaceae (53). Only 33 species are non-natives, generally with Eurasian origins. The reserve represents a transition between the southern Boreal and Grassland Subregions; over 50 species represent extensions to their ranges as mapped in the Flora of Alberta; for the most part these are some $50 \mathrm{~km}$ to $100 \mathrm{~km}$ from their next-nearest Grassland, Parkland and southern Boreal locations, but in several cases they are considerable distances from their Rocky Mountain or far northern or western Parkland ranges, as with Minuartia dawsonensis, Silene menziesii and Thalictrum occidentale. Of note are the 19 taxa that are currently listed by ANHIC as being provincially rare in Alberta, including Botrychium multifidum var, intermedium, Elodea ?bifoliata, Najas flexilis, Ruppia cirrhosa, Muhlenbergia asperifolia, Carex crawei, Carex ?houghtoniana, Carex parryana, Cyperus schweinitzii, Eleocharis ? elliptica, Chenopodium leptospermum, Drosera linearis, Asclepias ovalifolia, Gentiana fremontii, Lycopus americanus, Veronica ?catenata, Hedyotis longifolia, Aster pauciflorus and Shinneroseris rostrata. These species are bolded in the body of the list.

The plants are presented in the Engler Prantl sequence that appears in the Flora of Alberta (Moss 1983), and the nomenclature conforms to that used by ANHIC. Where there have been revisions to the nomenclature that are current elsewhere, or where it differs from the original citation, the synonyms are indicated with brackets: $(=)$. In many cases the subspecific or varietal level appropriate to the Alberta flora is added by the author, but was not included in the original lists of the previous surveyors. Species that are 
not native to Alberta are indicated by an asterisk $\left(^{*}\right)$ following the species name, and a question mark (?) indicates some query for the occurrence record. Species that occur immediately adjacent to the reserve boundaries and may be expected within the reserve are in parentheses.

\section{FERNS AND FERN ALLIES}

LYCOPODIACEAE

Lycopodium clavatum subsp. monostachyon

SELAGINELLACEAE

Selaginella densa var. densa

EQUISETACEAE

Equisetum arvense var. arvense, Equisetum fluviatile, Equisetum hyemale var. affine,

Equisetum pratense, Equisetum variegatum subsp. variegatum

OPHIOGLOSSACEAE

Botrychium multifidum var. intermedium

\section{GYMNOSPERMS}

\section{CUPRESSACEAE}

Juniperus communis var. depressa, Juniperus horizontalis

\section{MONOCOTYLEDONS}

\section{TYPHACEAE}

Typha latifolia

SPARGANIACEAE

Sparganium angustifolium var. chlorocarpum (= Sparganium chlorocarpum),

Sparganium (species)

POTAMOGETONACEAE

Potamogeton pectinatus (= Stuckenia pectinata), Potamogeton zosteriformis NAJADACEAE

Najas flexilis

RUPPIACEAE 
Ruppia cirrhosa ( $=$ R. maritima var. occidentalis)

ZANICHELLIACEAE

Triglochin maritimum, Triglochin palustris

ALISMATACEAE

Alisma plantago-aquatica, Sagittaria cuneata

HYDROCHARITACEAE

Elodea ?bifoliata (= Elodea canadensis, E. longivaginata)

POACEAE

(X Agrohordeum macounii), Agropyron desertorum*, Agropyron fragile*, Agropyron pectiniforme*, Agropyron repens*, Agropyron smithii var. smithii, Agropyron trachycaulum var. trachycaulum, Agropyron trachycaulum var. subsecundum and var. glaucum (= Elymus trachycaulus subsp. subsecundus), Agrostis scabra, Agrostis stolonifera var. palustris(*), Alopecurus aequalis, Beckmannia syzigachne subsp. baicalensis, Bouteloua gracilis, Bromus anomalus*, Bromus inermis subsp. inermis*, Calamagrostis canadensis, Calamagrostis inexpansa (= Calamagrostis stricta subsp. inexpansa), Calamagrostis stricta subsp. stricta, Calamovilfa longifolia var. Iongifolia, Catabrosa aquatica, Danthonia intermedia, Deschampsia cespitosa var. cespitosa, Distichlis stricta var. stricta, Elymus canadensis var. brachystachys, Festuca campestris (= Festuca scabrella), Festuca saximontana, (Festuca trachyphylla*), Glyceria borealis, Glyceria grandis, Glyceria striata var. stricta, Helictotrichon hookeri, Hierochloe odorata subsp. odorata (= Anthoxanthum nitens), Hordeum jubatum subsp. jubatum, Koeleria macrantha forma macrantha (= Koeleria cristata), Muhlenbergia asperifolia, Muhlenbergia glomerata, Muhlenbergia richardsonis, Oryzopsis asperifolia, Oryzopsis hymenoides, Oryzopsis pungens, Phleum pratense*, Poa arida, Poa compressa (*), Poa interior, Poa palustris, Poa pratensis var. pratensis*, Poa sandbergii, Puccinellia nuttalliana, Schizachne purpurascens var. purpurascens, Scolochloa festucacea, Sphenopholis intermedia (= Sphenopholis obtusata var. major), Sporobolus cryptandrus, Stipa comata, Stipa curtiseta (= Stipa spartea var. curtiseta), Stipa viridula ( $=$ Nassella viridula)

\section{CYPERACEAE}

Carex aquatilis var. aquatilis, Carex atherodes Carex aurea, Carex bebbii, Carex canescens (= Carex curta), Carex capillaris subsp. chlorostachys, Carex 
chordorrhiza, Carex crawei, Carex crawfordii, Carex diandra, Carex disperma, Carex douglasii, Carex filifolia, Carex gynocrates (= Carex dioica), Carex ?houghtoniana, Carex interior, Carex lanuginosa (= Carex lasiocarpa var. latifolia), Carex lasiocarpa var. americana, Carex leptalea, Carex limosa, (Carex livida), (Carex microptera), Carex obtusata, Carex parryana subsp. parryana, Carex peckii, Carex pensylvanica var. digyna (= Carex inops subsp. heliophila), Carex praegracilis, Carex prairea, Carex sartwellii, Carex scirpoidea var. scirpoidea, Carex siccata, Carex sprengelii, Carex stenophylla subsp. eleocharis (= Carex eleocharis), Carex tenuiflora, Carex utriculata (= Carex rostrata var. uttriculata), Carex vaginata, Carex viridula, Cyperus schweinitzii, Eleocharis acicularis, Eleocharis ?elliptica (= Eleocharis compressa var. ?borealis), Eleocharis palustris (= Eleocharis erythropoda), Eleocharis quinqueflora (= Eleocharis pauciflora var. fernaldii), Eriophorum chamissonis, Eriophorum gracilis, Eriophorum polystachion (= Eriophorum angustifolium), Eriophorum viridi-carinatum, Scirpus acutus, Scirpus caespitosus, Scirpus microcarpus var. rubrotinctus, Scirpus pungens subsp. pungens (= Scirpus americanus), Scirpus validus

LEMNACEAE

Lemna minor, Lemna trisulca

JUNCACEAE

Juncus alpinoarticulatus, Juncus balticus var. littoralis (= Juncus arcticus var. littoralis), Juncus bufonius, Juncus longistylis, Juncus nodosus, Juncus tenuis var. dudleyi, Luzula multiflora (= Luzula campestris var. multiflora)

LILIACEAE

Allium textile, Disporum trachycarpum, Lilium philadelphicum var. andinum,

Maianthemum canadense, Smilacina stellatum (= Maianthemum stellata), Smilacina trifolium (= Maianthemum trifolia), Tofieldia glutinosa var. glutinosa, Zigadenus elegans subsp. elegans

IRIDACEAE

Sisyrinchium montanum var. montanum

ORCHIDACEAE

Corallorhiza trifida, Cypripedium calceolus var. parviflorum, Habenaria dilatata (= Platanthera dilatata var. dilatata), Habenaria hyperborea (= Platanthera 
hyperborea), Habenaria obtusata (= Platanthera obtusata), Habenaria viridis var. bracteata $(=$ Coeloglossum viride), Spiranthes romanzoffiana

\section{CHORIPETALOUS DICOTYLEDONS}

\section{SALICACEAE}

Populus balsamifera var. balsamifera, Populus balsamifera var. ?trichocarpa, Populus tremuloides var. tremuloides, Salix bebbiana var. bebbiana, Salix candida, Salix discolor, (Salix lutea), Salix maccalliana, Salix myrtillifolia var. cordata, Salix myrtillifolia var. ?myrtillifolia, Salix pedicellaris, Salix petiolaris, Salix planifolia subsp. planifolia, Salix pseudomonticola, Salix serissima

BETULACEAE

(Alnus tenuifolia (= Alnus incana subsp. tenuifolia)), Betula neoalaskana, Betula occidentalis var. occidentalis, Betula papyrifera var. papyrifera, Betula pumila var. glandulifera, Corylus cornuta var. cornuta

URTICACEAE

Utrica dioica var. gracilis (= Urtica gracilis)

SANTALACEAE

Comandra umbellata var. pallida

POLYGONACEAE

Polygonum amphibium var. stipulaceum (= Polygonum natans forma hartwrightii), Polygonum arenastrum*, Polygonum convolvulus*, Polygonum erectum, Polygonum lapathifolium, Rumex acetosella subsp. acetosella*, Rumex maritimus var. fueginus, Rumex occidentalis, Rumex venosus

\section{CHENOPODIACEAE}

Atriplex prostrata*, Axyris amaranthoides*, Chenopodium album*, Chenopodium gigantospermum, Chenopodium ?leptophyllum, Chenopodium pratericola,

Chenopodium rubrum var. rubrum, Chenopodium salinum, Monolepis nuttalliana, Salicornia europaea subsp. rubra (= Salicornia rubra), Salsola kali var. tenuifolia*, Suaeda calceoliformis ( $=$ Suaeda depressa) AMARANTHACEAE

Amaranthus blitoides*, Amaranthus retroflexus* 


\section{NYCTAGINACEAE}

Mirabilis hirsuta

\section{CARYOPHYLLACEAE}

Cerastium arvense, Cerastium vulgatum * (= Cerastium fontanum subsp. vulgare), Minuartia dawsonensis, Moehringia lateriflora, Silene drummondii var. drummondii, Silene menziesii var. menziesii, Stellaria calycantha var. calycantha, Stellaria longifolia, Stellaria longipes

\section{CERATOPHYLLACEAE}

(Ceratophyllum demersum)

\section{RANUNCULACEAE}

Actaea rubra subsp. rubra, Anemone canadensis, Anemone cylindrica, Anemone multifida var, multifida, Anemone multifida var. richardsiana, Anemone patens var. multifida, (Caltha natans), Caltha palustris, Ranunculus abortivus, Ranunculus circinatus (= Ranunculus subrigidus), Ranunculus cymbalaria var. cymbalaria, Ranunculus gmelinii var. gmelinii, Ranunculus macounii, Ranunculus sceleratus var. multifidus, Thalictrum occidentale var. occidentale, Thalictrum venulosum var. venulosum

\section{BRASSICACEAE}

Arabis divaricarpa var. divaricarpa, Arabis holboelii var. retrofracta, (Camelina microcarpa*), Capsella bursa-pastoris*, Cardamine pensylvanica, Descurania pinnata var. brachycarpa, Descurania sophia*, Draba nemorosa var. leiocarpa, Erysimum asperum var. asperum, Erysimum inconspicuum, Lepidium densiflorum var. densiflorum, Lepidium ramosissimum, Lesquerella arenosa var. arenosa, Rorippa palustris var. palustris, Rorippa palustris var. ?hispida, Sisymbrium altissimum*, Thlaspi arvense*

\section{DROSERACEAE}

Drosera linearis, Drosera ?anglica,

\section{SAXIFRAGACEAE}

Heucheria richardsonii var. richardsonii, Mitella nuda

\section{PARNASSIACEAE}

Parnassia palustris var. neogaea (= Parnassia montanensis) 


\section{GROSSULARIACEAE}

Ribes americanum, Ribes hirtellum, Ribes lacustre, Ribes oxyacanthoides, Ribes triste ROSACEAE

(Agrimonia striata), Amelanchier alnifolia var. alnifolia, Chamaerhodos erecta var. nuttallii, Crataegus rotundifolia (= Crataegus chrysocarpa), Fragaria virginiana var. glauca, Geum aleppicum var. strictum, Geum macrophyllum var. ?macrophyllum, Geum macrophyllum var. perincisum, Geum triflorum var. triflorum, Potentilla anserina subsp. anserina, Potentilla arguta, Potentilla concinna var. concinna, Potentilla gracilis var. flabelliformis, Potentilla hippiana var. hippiana, Potentilla norvegica var. norvegica, Potentilla palustris var. palustris, Potentilla pensylvanica var. pensylvanica, Potentilla rivularis, Prunus pensylvanica var. pensylvanica, Prunus virginiana subsp. melanocarpa, Rosa acicularis, Rosa woodsii subsp. woodsii, Rubus idaeus subsp. melanolasius (= Rubus strigosus), Rubus pubescens, Spiraea alba var. alba

\section{FABACEAE}

Astragalus dasyglottis, (Astragalus flexuosus), Astragalus striatus, Glycerrhiza lepidota var. lepidota, Lathyrus ochroleucus, Lathyrus venosus subsp. intonsus, Medicago sativa subsp. sativa*, Oxytropis monticola (= Oxytropis campestris var. gracilis), Oxytropis sericea var. spicata, Psoralea argophylla, Thermopsis rhombifolia, Trifolium hybridum, Vicia americana var. americana, Vicia americana var. minor (= Vicia sparsifolia)

\section{GERANIACEAE}

Geranium richardsonii

LINACEAE

Linum lewisii subsp. lewisii (= Linum perenne)

\section{EUPHORBIACEAE}

Chamaesyce glyptospermum (= Euphorbia glyptosperma)

\section{CALLITRICHACEAE}

Callitriche verna (= Callitriche palustris)

\section{ANACARDIACEAE}

Rhus radicans var. rydbergii (= Toxicodendron radicans var. rydbergin) 


\section{MALVACEAE}

Sphaeralcea coccinea var. coccinea

\section{CISTACEAE}

Hudsonia tomentosa

\section{VIOLACEAE}

Viola adunca, Viola canadensis var. rugulosa (= Viola rugulosa), Viola nephrophylla,

Viola ?nuttallii var. major, Viola ?renifolia

\section{CACTACEAE}

Opuntia fragilis

ELAEAGNACEAE

Elaeagnus commutata, Shepherdia canadensis

ONAGRACEAE

Epilobium angustifolium subsp. angustifolium, Epilobium ciliatum subsp. glandulosum

(= Epilobium glandulosum), Epilobium leptophyllum, Gaura coccinea var. coccinea, Oenothera biennis, Oenothera nuttallii

HALORAGACEAE

Myriophyllum exalbescens (= Myriophyllum spicatum)

HIPPURIDACEAE

Hippuris vulgaris

ARALIACEAE

Aralia nudicaulis

\section{APIACEAE}

Cicuta bulbifera, Cicuta maculata var. angustifolia (= Cicuta douglasii), Heracleum lanatum, Osmorhiza depauperata, Sancula marilandica, Sium suave, Zizia aptera var. occidentalis

\section{CORNACEAE}

Cornus canadensis, Cornus stolonifera var. stolonifera (= Cornus sericea)

\section{SYMPETALOUS DICOTYLEDONS}

\section{PYROLACEAE}

Moneses uniflora var. uniflora, Orthilia secunda subsp. secunda (= Pyrola secunda), Pyrola asarifolia var. asarifolia, Pyrola chlorantha 


\section{ERICACEAE}

Arctostaphylos uva-ursi

PRIMULACEAE

Androsace septentrionalis, Dodecatheon pulchellum subsp. pulchellum

(=Dodecatheon radicatum), Glaux maritima subsp. maritima, Lysimachia ciliata (=

Steironema ciliatum), Lysimachia thyrsiflora, Primula incana

GENTIANACEAE

Gentiana fremontii, Gentianella amarella subsp. acuta, Gentianella crinita subsp. macounii (= G. macounii)

MENYANTHACEAE

Menyanthes trifoliata

APOCYNACEAE

Apocynum androsaemifolium var. androsaemifolium

ASCLEPIADACEAE

Asclepias ovalifolia

POLEMONIACEAE

Collomia linearis, Phlox hoodii subsp. canescens

BORAGINACEAE

Cryptantha fendlerii, Hackelia americana Lappula occidentalis, (= Lappula redowskit), Lithospermum incisum

LAMIACEAE

Dracocephalum parviflorum (= Moldavia parviflora), Lycopus americanus, Lycopus asper, Mentha arvensis var. glabrata, Monarda fistulosa var. menthaefolia, Prunella vulgaris subsp. lanceolatus, Scutellaria galericulata var. pubescens, Stachys palustris var. pilosa

SOLANACEAE

Solanum triflorum

SCROPHULARIACEAE

Castilleja miniata, Orthocarpus luteus, Pedicularis groenlandica, (Penstemon gracilis), (Veronica americana), (Veronica catenata (= Veronica salina)), Veronica peregrina var. xalapensis 


\section{OROBANCHACEAE}

(Orobanche fasciculata var. fasciculata)

\section{LENTIBULARIACEAE}

Pinguicula vulgaris var. vulgaris, Utricularia intermedia, Utricularia minor, Utricularia vulgaris subsp. macrorhiza

\section{PLANTAGINACEAE}

Plantago major var. major

\section{RUBIACEAE}

Galium boreale var. intermedium, Galium labradoricum, Galium trifidum var. trifidum, Galium triflorum, Hedyotis Iongifolia (= Houstonia longifolia)

\section{CAPRIFOLIACEAE}

Linnaea borealis var. americana, Lonicera dioica var. glaucescens, Symphoricarpos albus var. albus, Symphoricarpos occidentalis, Viburnum edule, Viburnum opulus var. americanum (= Viburnum trilobum)

\section{CAMPANULACEAE}

Campanula rotundifolia

\section{LOBELIACEAE}

Lobelia kalmii

\section{ASTERACEAE}

Achillea millefolium subsp. lanulosa, Agoseris glauca, Ambrosia artemisifolia var. elatior, Antennaria parvifolia, (Antennaria pulcherrima), Artemisia biennis, Artemisia campestris subsp. caudata (= Artemisia forwardii), Artemisia dracunculus var. dracunculus, Artemisia frigida var. frigida, Artemisia ludoviciana var. Iudoviciana, Artemisia ludoviciana var. gnaphaloides, Aster borealis (= Aster junciformis) , Aster brachyactis, Aster ciliolatus, Aster ericoides subsp. pansus (= Aster pansus, Virgulus ericoides), Aster hesperius var. hesperius, Aster laevis var. geyeri, Aster pauciflorus (= Almutaster pauciflorus), Bidens cernua, Cirsium arvense var. arvense*, Cirsium flodmanii, Cirsium undulatum, Cirsium vulgare*, Crepis runcinata subsp. runcinata, Crepis tectorum*, Erigeron annuus subsp. septentrionalis (= Erigeron strigosus), Erigeron caespitosus, Erigeron ?elatus, Erigeron glabellus subsp. glabellus, Erigeron glabellus subsp. pubescens, Erigeron lonchophyllus, Erigeron philadelphicus, Gaillardia aristata, Gridelia squarrosa var. squarrosa, Helenium autumnale var. 
montanum, Helianthus couplandii, Helianthus subrhomboideus (= Helianthus laetiflorus var. subrhomboideus), Heterotheca villosa var. villosa (= Chrysopsis villosa), Lactuca pulchella subsp. pulchella, (Liatris ligulistylis), Lygodesmia juncea, Matricaria matricarioides* (= Matricaria suaveolens), Petasites frigidus var. palmatus (= Petasites palmatus), Petasites sagittatus (= Petasites frigidus var. sagittatus), Petasites vitifolius, Ratibida columnifera, Senecio canus (= Packera cana), Senecio congestus, Senecio pauperculus (= Packera paupercula), Shinneroseris rostrata (= Lygodesmia rostrata), Solidago canadensis var. canadensis, Solidago gigantea var. serotina, Solidago graminifolia (= Euthamia graminifolia var. graminifolia), Solidago missouriensis var. fasciculata, Solidago nemoralis var. Iongipetiolata, Solidago rigida, Solidago spathulata var. neomexicana (= Solidago decumbens var. ereophila), Sonchus uliginosus*, (= Sonchus arvensis var. uliginosus), Sonchus asper*, Taraxacum officinale*, Tragopogon dubius*

\section{REFERENCES}

ANHIC Records for Tracked Species Occurrences. 26 May 2002. Alberta Natural Heritage Information Centre, Alberta Community Development, Edmonton.

Bradley, L. and C. Bradley. 1977. Aspen Grove resource assessment: Wainwright area. Parks Planning and Design Branch, Alberta Recreation, Parks and Wildlife, Edmonton.

Cotterill, Patsy. 15 July 2000. (observation and collection records), and 2003 (pers. comm. - I.D. Macdonald - 4 March 2003).

Cottonwood Consultants, Ltd. 1986. The Proposed Wainwright Ecological Reserve-A Biophysical Overview. Alberta Recreation and Parks, Edmonton.

Fehr, A. 1984. Wainwright Study Area: Biophysical Inventory. Natural Areas Program, Public Lands Division, Alberta Energy and Natural Resources, Technical Report No. $1 / 65$, Edmonton. (Fb indicates where Fehr only cites the Bradley's record but apparently did not actually see it himself; several species occurrence records were excluded from this list in $\mathrm{P}$ (see below) and in the present list).

Johnson, Derek. 29 July 1992. (observation and collection records).

Macdonald, Ian D. 12 - 16 June 2002, 10 - 21 July 2002, 15 - 19 August 2002. (observation 
and collection records).

Miejer, M. 2001. Survey of Rare Plant Element Occurrences in the Central Parkland Natural Subregion (includes Rare Native Plant Forms). open file, ANHIC, Edmonton.

Wainwright Dunes Ecological Reserve Management Plan. February 1998. Alberta Agriculture, Food and Rural Development, and Alberta Environmental Protection, Edmonton. (includes 1998 contributions from Wallis, Cotterill and Johnson).

Wallis, Cliff. 1990. Reconnaissance Survey of Saline Wetlands and Springs in the Grassland - Parkland Region of Eastern Alberta. Cottonwood Consultants, Ltd., Calgary and Alberta Lands, Forestry and Wildlife (Natural and Protected Areas), for World Wildlife Fund Canada and Alberta Forestry, Lands and Wildlife, Prairie for Tomorrow, Edmonton. 


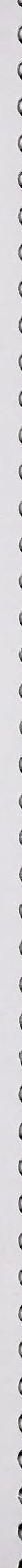



